\title{
ANNUAL REPORT TO CONGRESS
}

\section{Department of Energy Activities \\ Relating to the \\ Defense Nuclear Facilities Safety Board}

\author{
Calendar Year 1999
}

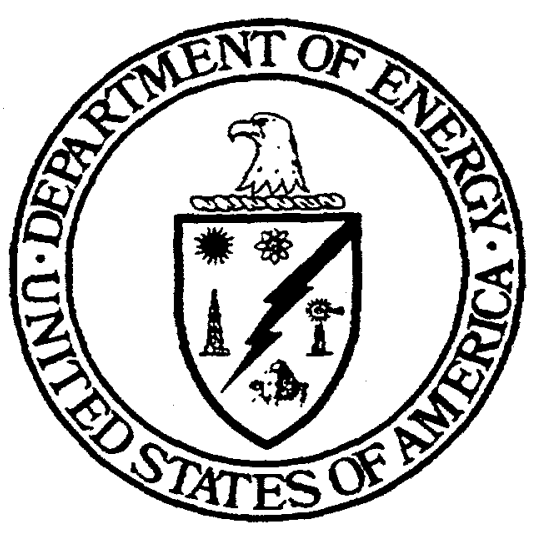

Washington, D.C. 20585

February 2000 


\section{DISCLAIMER}

This report was prepared as an account of work sponsored by an agency of the United States Government. Neither the United States Government nor any agency thereof, nor any of their employees, make any warranty, express or implied, or assumes any legal liability or responsibility for the accuracy, completeness, or usefulness of any information, apparatus, product, or process disclosed, or represents that its use would not infringe privately owned rights. Reference herein to any specific commercial product, process, or service by trade name, trademark, manufacturer, or otherwise does not necessarily constitute or imply its endorsement, recommendation, or favoring by the United States Government or any agency thereof. The views and opinions of authors expressed herein do not necessarily state or reflect those of the United States Government or any agency thereof. 


\section{DISCLAIMER}

Portions of this document may be illegible in electronic image products. Images are produced from the best available original document. 


\section{The Secretary of Energy \\ Washington, DC 20585}

February 9, 2000

The Honorable Al Gore, Jr.

President of the Senate

Washington, D.C. 20510

Dear Mr. President:

Section 316(b) of the Atomic Energy Act of 1954 requires the Department of Energy (Department) to submit a written report to Congress addressing the Department's activities related to the Defense Nuclear Facilities Safety Board (Board). I am pleased to forward the Department's Annual Report for Calendar Year 1999.

During 1999, the Department completed its implementation and proposed closure of nine Board recommendations. In addition, the Department has completed all implementation plan milestones associated with three other Board recommendations. The Department received and accepted one new Board recommendation in 1999 and is developing a new implementation plan to address this recommendation.

The Department also has made significant progress in carrying over a number of broad-based initiatives to improve safety. These include expanded implemention and institutionalization of integrated safety management at field sites, opening a repository for long-term storage of transuranic wastes, and preparing a revised plan for stabilizing excess nuclear materials to achieve significant risk reduction.

If you have any questions, please contact me or have a member of your staff contact Mr. Mark B. Whitaker, Jr., Departmental Representative to the Board, at (202) $586-3887$.

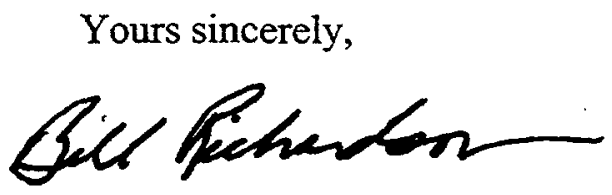

Bill Richardson

Enclosure 


\section{TABLE OF CONTENTS}

\section{LETTER TO CONGRESS}

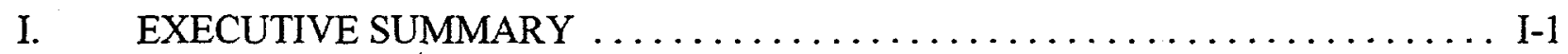

II. KEY DEPARTMENT SAFETY INITIATIVES $\ldots \ldots \ldots \ldots \ldots \ldots \ldots \ldots \ldots \ldots \ldots \ldots \ldots \ldots$ II -1

A. Stabilization of Excess Nuclear Materials $\ldots \ldots \ldots \ldots \ldots \ldots \ldots \ldots \ldots$ II -1

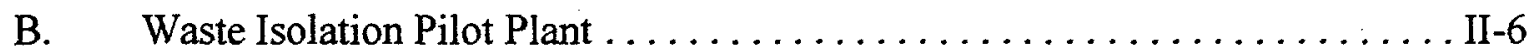

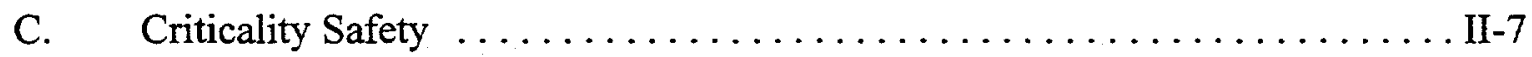

D. Management Structure Reorganization $\ldots \ldots \ldots \ldots \ldots \ldots \ldots \ldots \ldots \ldots \ldots \ldots \ldots$ II -9

E. Project Management Reform Initiative $\ldots \ldots \ldots \ldots \ldots \ldots \ldots \ldots \ldots$ II -9

F. Integrated Safety Management $\ldots \ldots \ldots \ldots \ldots \ldots \ldots \ldots \ldots \ldots \ldots \ldots \ldots$ II -10

III. IMPLEMENTATION OF BOARD RECOMMENDATIONS $\ldots \ldots \ldots \ldots \ldots \ldots$ III-1

A. Recommendation Closures $\ldots \ldots \ldots \ldots \ldots \ldots \ldots \ldots \ldots \ldots \ldots \ldots \ldots \ldots$ III-1

B. Recommendation Proposed for Closure $\ldots \ldots \ldots \ldots \ldots \ldots \ldots \ldots$ III-14

C. New Recommendation and Implementation Plan .............. III-16

D. Other Active Implementation Plans . ................... III-17

E. Report on Implementation Plans Requiring More Than One Year ...... III-26

F. Categorization of Board Recommendations ................ III-27

IV. OTHER BOARD INTERFACE ACTIVITIES $\ldots \ldots \ldots \ldots \ldots \ldots \ldots \ldots \ldots \ldots \ldots \ldots \ldots$ IV-1

\section{APPENDICES}

A Orders and Departmental Safety Directives of Interest to the Board $\ldots \ldots \ldots \ldots$ A-1

B Site Visits Supported by the Department in $1999 \ldots \ldots \ldots \ldots \ldots \ldots \ldots \ldots$.

C Key Department/Board Correspondence in $1999 \ldots \ldots \ldots \ldots \ldots \ldots \ldots$ C-1 


\section{EXECUTIVE SUMMARY}

This is the tenth Annual Report to the Congress describing Department of Energy (Department) activities in response to formal recommendations and other interactions with the Defense Nuclear Facilities Safety Board (Board). The Board, an independent executive-branch agency established in 1988, provides advice and recommendations to the Secretary of Energy regarding public health and safety issues at the Department's defense nuclear facilities. The Board also reviews and evaluates the content and implementation of health and safety standards, as well as other requirements, relating to the design, construction, operation, and decommissioning of the Department's defense nuclear facilities. Figure 1 (page I-5) provides the locations of the major Department facilities.

During 1999, Departmental activities resulted in the closure of nine Board recommendations. In addition, the Department has completed all implementation plan milestones associated with three Board recommendations. One new Board recommendation was received and accepted by the Department in 1999, and a new implementation plan is being developed to address this recommendation.

The Department has also made significant progress with a number of broad-based initiatives to improve safety. These include expanded implementation of integrated safety management at field sites, opening of a repository for long-term storage of transuranic wastes, and continued progress on stabilizing excess nuclear materials to achieve significant risk reduction.

\section{Recommendations Closed}

Table 1 (page I-6) provides a summary status on Board recommendations. Department activities culminating in 1999 led to the proposed closure of the following Board recommendations:

- $\quad$ Recommendation 95-1, Improved Safety of Cylinders Containing Depleted Uranium

- Recommendation 94-5, Integration of Department of Energy Safety Rules, Orders, and Other Requirements

- Recommendation 94-4, Deficiencies in Criticality Safety at Oak Ridge Y-12 Plant

- Recommendation 94-3, Rocky Flats Seismic and Systems Safety

- Recommendation 94-2, Conformance with Safety Standards at Low-Level Nuclear Waste and Disposal Sites

- Recommendation 93-6, Maintaining Access to Nuclear Weapons Expertise in the Defense Nuclear Facilities Complex 


\section{Annual Report to Congress}

- $\quad$ Recommendation 93-5, Tank Waste Characterization Studies

- Recommendation 93-3, Improving Technical Capability in Defense Nuclear Programs

- Recommendation 93-1, Standards Utilization in Defense Nuclear Facilities

In addition, the Department has completed all of the milestone deliverables for three additional implementation plans:

- $\quad$ Recommendation 97-1, Safe Storage of Uranium-233,

- Recommendation 95-2, Safety Management

- Recommendation 92-4, Multi-Function Waste Tank Facility at Hanford. (Closure proposed in December 1998)

\section{New Recommendations and Implementation Plans}

In 1999 the Department formally accepted one new recommendation received from the Board, recommendation 99-1, Safe Storage of Pits at the Pantex Plant.

Table 2 (page I-7) provides key dates for active Board recommendations.

\section{Trend in the Number of Open Board Recommendations}

The following trending data illustrate the change in the number of open Board recommendations for each year since the inception of the Board.

\begin{tabular}{|c|c|c|c|c|}
\hline Year & $\begin{array}{c}\text { Recommendations } \\
\text { Issued }\end{array}$ & $\begin{array}{c}\text { Recommendations } \\
\text { Closed }\end{array}$ & $\begin{array}{c}\text { Net Change in Open } \\
\text { Recommendations }\end{array}$ & $\begin{array}{c}\text { Open Recommendations } \\
\text { at Year End }\end{array}$ \\
\hline 1990 & 7 & 0 & +7 & 7 \\
\hline 1991 & 6 & 0 & +6 & 13 \\
\hline 1992 & 7 & 8 & -1 & 12 \\
\hline 1993 & 6 & 1 & +5 & 17 \\
\hline 1994 & 5 & 1 & +4 & 21 \\
\hline 1995 & 2 & 6 & -4 & 17 \\
\hline 1996 & 1 & 4 & -3 & 14 \\
\hline 1997 & 2 & 1 & +1 & 15 \\
\hline 1998 & 2 & 0 & +2 & 17 \\
\hline 1999 & 1 & 9 & -8 & 9 \\
\hline
\end{tabular}


The above data reflect the evolution of the recommendation process. Initially, Board recommendations primarily addressed specific, highly technical significant safety issues within the Department's activities. Over time, the Board and the Department have worked cooperatively to address these risks, and to establish fundamental, integrated programs to improve the Department's overall safety management process. Success in this area, combined with an increased use of letters and other communication methods, has led to the issuance of fewer, often more broad-based recommendations in recent years. The Department intends to continue to pursue closure of applicable recommendations as a priority in 2000. This will allow the Department to focus resources on resolution of the fundamental safety issues addressed by the remaining open recommendations or identified through other mechanisms.

\section{Summary of the Department's Major Safety Accomplishments}

Concrete accomplishments over the past four years that have contributed to improved safety at Department facilities include the following:

- Identifying over 740 critical skill federal technical positions, and taking action to preserve this capability against the potential adverse affects of downsizing activities;

- Developing and accelerating the implementation of a Department-wide safety management system at ten priority facilities;

- Extending the scope of the integrated safety management program where it is appropriate to all Department facilities;

- Improving the technical capability of the Department's federal work force;

- $\quad$ Stabilizing the majority of high risk excess nuclear materials;

- $\quad$ Establishing qualified Facility Representatives at key sites and facilities;

- Institutionalizing highly effective Operational Readiness Reviews;

- Instituting contract reform to clarify safety management expectations for Department contractors;

- Archiving irreplaceable expertise and experience on criticality, weapons operation, and testing;

- Formalizing the safety roles and responsibilities throughout the Department by issuing the Functions, Responsibilities, and Authorities Manuals;

- Developing a process to improve the effectiveness of the criticality safety program; and

- Completed design and development of a new pit storage container and began repackaging pits in July 1999. 


\section{Department Focus for 2000}

In 2000, the Department intends to keep focus on assuring that implementation plans remain valid and workable, managing actions to completion by the identified due dates, and proposing closure of recommendations when the underlying safety issues are resolved. The most significant challenges involve safety issues which are complex-wide in nature and involve culture changes:

- $\quad$ systematically institutionalizing a consistent safety management system which integrates all elements of safety (e.g., public health, occupational safety, environmental protection) into management and work practices at all levels so that work can be accomplished while protecting the public, the worker, and the environment,

- $\quad$ sustaining progress on stabilizing excess nuclear material,

- implementing an integrated, Department-wide material disposition process, and

- institutionalizing improvements in the effectiveness of the criticality safety program.

The above listed items are long-term issues which will take a dedicated, multi-year effort to successfully resolve. The Department is committed to these ongoing efforts and does not foresee major shifts or re-direction in these core safety initiatives, thus providing continuity of direction for headquarters, field, and contractor organizations. The primary challenge associated with these safety initiatives continues to be the need to effectively integrate them in a manner that assures a consistent level of protection.

\section{Report Preview}

The remaining portions of the annual report provide the contents described below:

- $\quad$ Section II, KEY DEPARTMENT SAFETY INITIATIVES, describes broad-based Department activities which affect environment, safety and health;

- Section III, IMPLEMENTATION OF BOARD RECOMMENDATIONS, describes Department activities completed in 1999 to implement Board recommendations accepted by the Secretary; and

- $\quad$ Section IV, OTHER BOARD INTERFACE INITIATIVES, describes Department activities to maintain communications and improve interaction between the Department and the Board. 


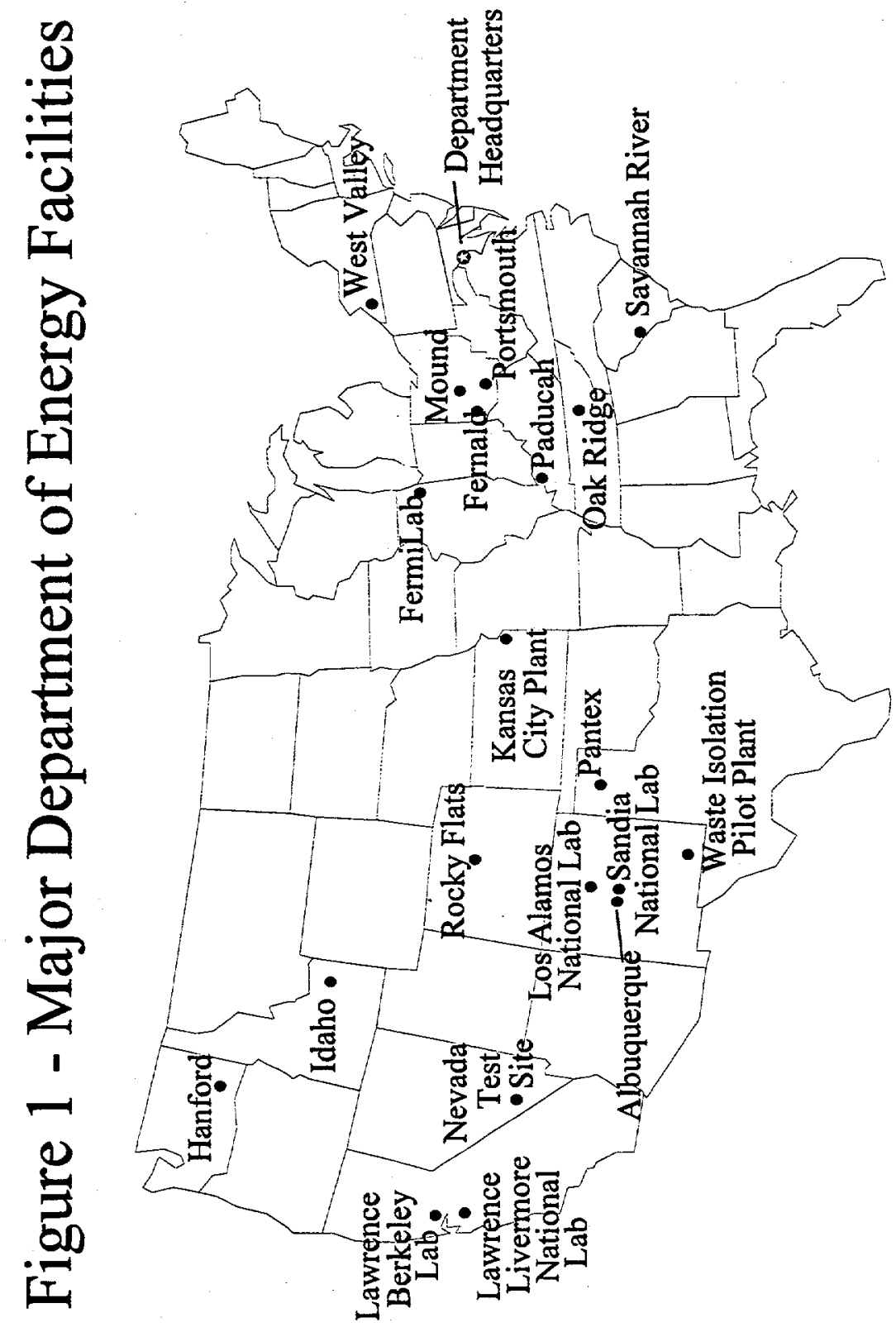




\section{Table 1 Summary Status of Board Recommendations}

\begin{tabular}{|c|c|c|c|}
\hline REC & SUBJECT & OPEN & CLOSED \\
\hline $90-1$ & Savannah River Operator Training & & $10 / 27 / 92$ \\
\hline $90-2$ & Codes and Standards & & $10 / 24 / 95$ \\
\hline $90-3$ & Hanford Waste Tanks & & $5 / 1 / 92$ \\
\hline $90-4$ & Rocky Flats Operational Readiness Reviews & & $2 / 16 / 95$ \\
\hline $90-5$ & Systematic Evaluation Plans & & $10 / 24 / 95$ \\
\hline $90-6$ & Rocky Flats, Plutonium in the Ventilation Ducts & & $10 / 24 / 95$ \\
\hline $90-7$ & Hanford Waste Tanks - Ferrocyanide Safety Issue & & $9 / 4 / 96$ \\
\hline $91-1$ & Safety Standards Program & & $10 / 27 / 92$ \\
\hline $91-2$ & Reactor Operations Management Plan at Savannah River & & $10 / 27 / 92$ \\
\hline $91-3$ & Waste Isolation Pilot Plant & & $10 / 27 / 92$ \\
\hline $91-4$ & Rocky Flats, Building 559 Operational Readiness Review & & $5 / 1 / 92$ \\
\hline $91-5$ & Savannah River K Reactor Power Limits & & $4 / 7 / 93$ \\
\hline $91-6$ & Radiation Protection & & $11 / 8 / 96$ \\
\hline $92-1$ & Operational Readiness of the HB-Line at Savannah River & & $10 / 27 / 92$ \\
\hline $92-2$ & Facility Representatives & & $9 / 17 / 96$ \\
\hline $92-3$ & HB-Line Operational Readiness Reviews at Savannah River & & $2 / 3 / 93$ \\
\hline $92-4$ & Multi-Function Waste Tank Facility at Hanford & $\underline{x}$ & \\
\hline $92-5$ & Discipline of Operations & & $10 / 24 / 95$ \\
\hline $92-6$ & Operational Readiness Reviews & & $10 / 24 / 95$ \\
\hline $92-7$ & Training and Qualification & & $11 / 4 / 93$ \\
\hline $93-1$ & Standards Utilization in Defense Nuclear Facilities & & $3 / 25 / 99$ \\
\hline $93-2$ & Critical Experiments Capability & & $12 / 30 / 97$ \\
\hline $93-3$ & Improving Technical Capability & & $11 / 9 / 99$ \\
\hline $93-4$ & Environmental Restoration Management Contracts & & $6 / 28 / 96$ \\
\hline $93-5$ & Hanford Waste Tanks Characterization Studies & & $11 / 15 / 99$ \\
\hline $93-6$ & Nuclear Weapons Expertise & & $4 / 27 / 99$ \\
\hline $94-1$ & Improved Schedule for Remediation & $\underline{x}$ & \\
\hline $94-2$ & Safety Standards for Low Level Waste & & $12 / 22 / 99$ \\
\hline $94-3$ & Rocky Flats Seismic and Systems Safety & & $5 / 27 / 99$ \\
\hline $94-4$ & Deficiencies in Criticality Safety at Oak Ridge Y-12 & & $3 / 12 / 99$ \\
\hline $94-5$ & Rules, Orders, and Other Requirements & & $6 / 10 / 99$ \\
\hline $95-1$ & Improved Safety of Cylinders Containing Depleted Uranium & & $12 / 16 / 99$ \\
\hline $95-2$ & Safety Management & $\mathrm{X}$ & \\
\hline $96-1$ & In-Tank Precipitation System at Savannah River & $\mathrm{X}$ & \\
\hline $97-1$ & Safe Storage of Uranium-233 & $\mathrm{x}$ & \\
\hline $97-2$ & Criticality Safety & $\mathrm{x}$ & \\
\hline $98-1$ & Resolution of Internal Oversight Findings & $\mathrm{X}$ & \\
\hline $98-2$ & Safety Management at the Pantex Plant & $\mathrm{X}$ & \\
\hline $99-1$ & Safe Storage of Pits at the Pantex Plant & $\mathrm{X}$ & \\
\hline
\end{tabular}


Table 2

Key Dates For Active Board Recommendations

\begin{tabular}{|c|l|c|c|c|}
\hline REC & \multicolumn{1}{|c|}{ SUBJECT } & $\begin{array}{c}\text { REC } \\
\text { DATE }\end{array}$ & $\begin{array}{c}\text { RESPONSE } \\
\text { DATE }\end{array}$ & $\begin{array}{c}\text { IMPL. } \\
\text { PLANE } \\
\text { DATE }\end{array}$ \\
\hline $92-4$ & Multi-Function Waste Tank Facility at Hanford & $7 / 6 / 92$ & $8 / 28 / 92$ & $\begin{array}{c}10 / 8 / 97 \\
\text { Rev. 2) }\end{array}$ \\
\hline $94-1$ & Improved Schedule for Remediation & $5 / 26 / 94$ & $8 / 31 / 94$ & $\begin{array}{c}12 / 28 / 98 \\
(\text { Rev. } 1)\end{array}$ \\
\hline $95-2$ & Safety Management & $10 / 11 / 95$ & $1 / 18 / 96$ & $4 / 18 / 96$ \\
\hline $96-1$ & In-Tank Precipitation System at Savannah River & $8 / 14 / 96$ & $9 / 16 / 96$ & $11 / 12 / 96$ \\
\hline $97-1$ & Safe Storage of Uranium-233 & $3 / 3 / 97$ & $4 / 25 / 97$ & $9 / 29 / 97$ \\
\hline $97-2$ & Criticality Safety & $5 / 19 / 97$ & $7 / 14 / 97$ & $12 / 12 / 97$ \\
\hline $98-1$ & Resolution of Internal Oversight Findings & $9 / 28 / 98$ & $11 / 20 / 98$ & $3 / 10 / 99$ \\
\hline $98-2$ & Safety Management at the Pantex Plant & $9 / 30 / 98$ & $11 / 20 / 98$ & $4 / 22 / 99$ \\
\hline $99-1$ & Safe Storage of Pits at the Pantex Plant & $8 / 11 / 99$ & $10 / 12 / 99$ & January \\
\hline
\end{tabular}




\section{KEY DEPARTMENT SAFETY INITIATIVES}

Each of the key initiatives described below involves significant changes from past operating practices. They involve systems-based solutions, cross-organizational/site integration, cross-program integration, and fundamental culture changes to address the underlying safety and management issues. For example, Department determinations about ultimate pathways and long-term dispositions for hazardous materials require deliberate study and integration across the defense nuclear facilities complex. Funding and management of Department-wide efforts to maintain strong criticality prediction and control capabilities requires cross-program coordination. The ongoing transition from expert-based safety management to requirements-based safety management systems continues to be a significant cultural adjustment which needs to be achieved in all parts and at every level of the organization. These changes undo many years of practices developed by sites, facilities, programs, and organizations operating largely independently and autonomously. Nevertheless, the Department is making progress overcoming these difficult challenges to establish a safety culture which is systems-based, requirementsbased, and integrated across programs, organizations, and facilities.

\section{A. Stabilization of Excess Nuclear Materials}

In February 1995, the Department established a program and plan for expediting remediation and stabilization of excess nuclear materials into safe, stable states for interim and long-term storage pending ultimate disposition. The halt in materials production for nuclear weapons froze the manufacturing pipeline in an intermediate state that was not optimal for long-term storage. Specifically, certain liquids and solids containing fissile materials and other radioactive substances located in spent fuel storage pools, reactor basins, reprocessing canyons, and various other facilities once used for processing and weapons manufacture needed to be stabilized.

Stabilization efforts were grouped by material types to take advantage of synergies. Six major categories of excess nuclear materials were identified: plutonium solutions, plutonium metals and oxides, plutonium residues and mixed oxides, special isotopes, certain uranium, and spent nuclear fuel. To date, the majority of high risk materials has in fact been stabilized, specifically:

- Plutonium metal in direct contact with plastic, and which required immediate attention, has been repackaged.

- The largest volumes of plutonium solutions have been stabilized.

- $\quad$ Significant progress has been achieved in stabilizing high risk spent fuel and building spent fuel storage facilities. 
As the remaining high risk material stabilization activities continue to be pursued, other activities are focusing on managing the stabilization of more difficult, diverse material groups such as plutonium residues.

The Nuclear Materials Stabilization Task Group, established in February 1995 and incorporated into the Office of Nuclear Materials and Spent Fuel in November 1999, integrates the Department's programs for stabilizing excess nuclear material to achieve safe, stable states for interim and long-term storage pending ultimate disposition. This office has established an integrated, complex-wide program for managing nuclear materials stabilization activities. To date, stabilization activities have been addressed complex-wide in the following areas:

- Developing integrated Department-wide approaches to stabilization issues;

- $\quad$ Evaluating facility stabilization capabilities;

- Preparing facilities to support spent fuel and nuclear material removal and consolidation for long term storage; and

- $\quad$ Procuring standardized equipment to support plutonium oxide stabilization and packaging for long-term storage.

There were a total of 164 commitments in the original February 1995 implementation plan for recommendation 94-1. The Department completed 106 or $65 \%$ of those original commitments when the Revision 1 of the implementation plan was approved by the Secretary in December 1998. A total of 57 of the completed 106 actions mitigated the urgent risks highlighted by the Board in recommendation 94-1. There is only one action still open in the urgent risk category which deals with stabilization of plutonium solutions stored at the Hanford Plutonium Finishing Plant. Sufficient compensatory measures are in place to ensure those plutonium liquids will not pose undue risk to our workers.

Revision 1 of the implementation plan contains a total of 55 commitments. Of those, 14 or $25 \%$ have been completed to date. The Department has continued to make progress in stabilizing nuclear materials, but it is not sufficient to just look at the numbers of commitments alone to gain an understanding of the types and amounts of materials that have been stabilized. For example: $89 \%$ of all Pu solutions, $58 \%$ of residues and mixed oxides, $39 \%$ of special isotopes, $18 \%$ of uranium solids and $7 \%$ of spent nuclear fuel have been stabilized as shown in Figure 2 (page II-3). 


\section{Figure 2 Completed Actions: Material Stabilization Progress}

Some of the completed actions to date at each site are described below:

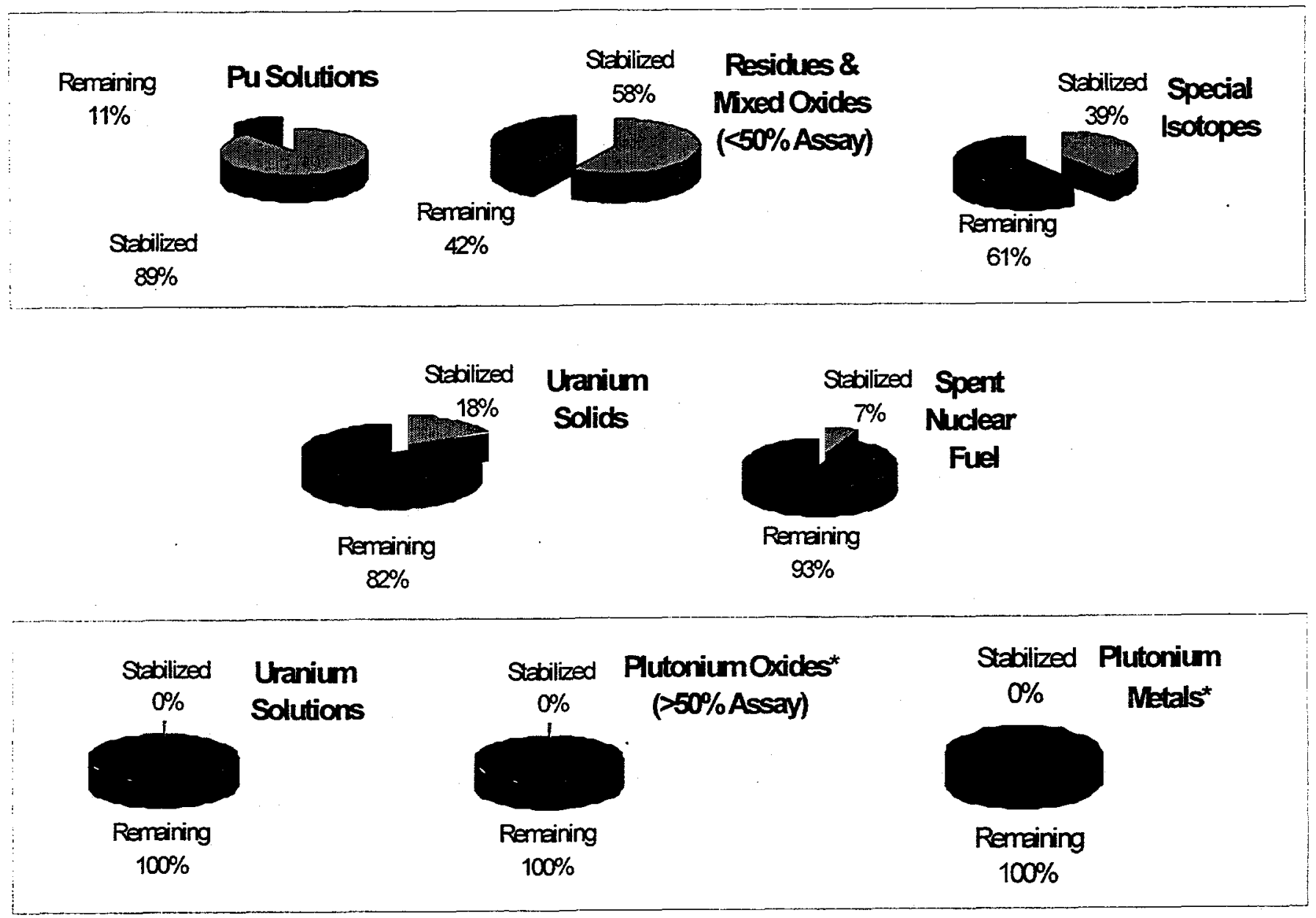

*Stabilization of metals and oxides indudes packaging to meet DOE STD-3013-96

Materials Stabilized

Materials Remaining

\section{Hanford}

- $\quad$ High risk ash stabilized

- All bottles of Plutonium solution checked to ensure proper venting

- Thermal stabilization of Pu oxides was reinitiated in January 1999 , with over 150 items stabilized as of 10/1/99 
- $\quad$ "Suspect Items" in bulged or paneled cans in glovebox 636 were mitigated

- The prototype vertical denitration calciner was restarted in September 1999

- Extensive testing of Pu polycubes at PFP and PNNL has initiated stabilization of these items and may lead to acceleration in mitigation of the risk in storage of these materials

- Magnesium hydroxide precipitation stabilization of $\mathrm{Pu}$ solutions has been initiated in the PFP Laboratory during development efforts

- Cofferdams (seismic isolation barriers) installed at K-Basins which minimize the potential for environmental release

- Completed installation of the Integrated Water Treatment System at K-West Basin

- Completed installation of the Fuel Retrieval System at K-West Basin

- $\quad$ More than 90 percent complete with building the Cold Vacuum Drying Facility

- Canister Storage Building subproject is more than 90 percent complete with building construction activities completed

\section{Los Alamos National Laboratory}

- Performed 100 percent visual inspection of vault inventory

- $\quad$ Stabilized all high-risk vault items

\section{Lawrence Livermore National Laboratory}

- Performed 100 percent verification of no plutonium metal in contact with plastic

\section{$\underline{\text { Oak Ridge }}$}

- Uranium deposits with criticality potential removed at K-25 and K-29

- Interim actions taken to preclude criticality at MSRE

- Potentially explosive fluorinated charcoal denatured

- Over 50 percent of uranium inventory removed as gaseous Uranium Hexafluoride

Mound

- All plutonium metal in contact with plastic has been repackaged

\section{$\underline{\text { Rocky Flats }}$}

- Vented all 2,662 residue drums

- Drained all tanks of high-level plutonium solutions (over 16 tanks) and stabilized solutions 
- $\quad$ All plutonium metal in contact with plastic has been repackaged

- $\quad$ Started processing all major residue categories

- All highly-enriched uranium solutions $(2,700 \mathrm{~L})$ shipped off-site and stabilized

\section{Savannah River}

- $\quad$ Stabilized 303,000 liters of plutonium-239 solutions

- $\quad$ Stabilized 13,300 liters of plutonium-242 solution

- $\quad$ Stabilized all Mark-31 targets

- All plutonium metal in contact with plastic has been repackaged

- All plutonium metal onsite has been packaged in a DOE-STD-3013 inner container

- Approximately $500 \mathrm{Mk}-16 / 22$ spent fuel assemblies have been dissolved

During 1999 the Department commenced a reevaluation of its plans for storage of excess weapons useable plutonium awaiting disposition. Completion of this reevaluation is expected in March 2000. Also during 1999, the Department completed a rebaselining of plutonium stabilization activities at the Hanford Plutonium Finishing Plant. The modifications to the Department's 94-1 implementation plan resulting from the Hanford rebaselining are reflected in a revision which is expected to be approved by the Secretary early this year.

In addition, the following activities were accomplished during 1999 to improve the Department's ability to accomplish the requirements during the remaining stabilization phase of the 94-1 activities.

Environmental Impact Statement on Management of Certain Plutonium Residues and Scrub Alloy Stored at the Rocky Flats Environmental Technology Site

The "Environmental Impact Statement on Management of Certain Plutonium Residues and Scrub Alloy Stored at the Rocky Flats Environmental Technology Site" was prepared to evaluate alternatives for management of these materials, thus providing the basis for determining whether they should be processed to allow their disposal or other disposition. Records of Decision were published for this Environmental Impact Statement on December 1, 1998, and February 18, 1999, and an amendment concerning plans for sand, slag and crucible residues was issued on September 1, 1999. Current plans call for the majority of Rocky Flats' plutonium residues to be prepared for disposal in the Waste Isolation Pilot Plant, and for the fluoride residues and scrub alloy to be shipped to the Savannah River Site for processing prior to disposition. 
Plutonium Storage Standard

Working in cooperation with the Offices of Defense Programs, Environmental Management, and Fissile Materials Disposition, the Nuclear Materials Stewardship Project Office (NMSPO) at the Albuquerque Operations Office sponsored the development of a revision to the technical standard for storage of plutonium, DOE-STD-3013-96, "Criteria for Preparing and Packaging Plutonium Metals and Oxides for Long Term Storage." The 1996 version of the standard applied to metals and oxides with at least $50 \%$ plutonium, which were originally the materials in greatest need of storage criteria. However, Environmental Management's continued progress in cleaning up Department sites that formerly produced or processed nuclear materiais created a need for a standard that would address materials with lower plutonium content. The revised standard addresses stabilization, packaging, and storage of such materials.

Work on the revised standard began in January 1998. A core team was assembled to collect the technical information to support the new standard. A working group was convened in March of that year and the revised standard was drafted in 1998. The draft standard was ready for coordination by the spring of 1999 when a review and comment period was initiated. After comments were resolved, the final standard (DOE-STD-301399) was prepared and approved in December 1999.

\section{B. Waste Isolation Pilot Plant (WIPP)}

The Waste Isolation Pilot Plant (WIPP) facility, a cornerstone of the Department's cleanup effort, is the world's first underground deep geologic repository for the permanent disposal of defense-generated transuranic waste left from years of research and production of nuclear weapons. Since opening March 26, 1999, WIPP has received shipments of transuranic waste from the Los Alamos National Laboratory (LANL), the Idaho National Engineering and Environmental Laboratory (INEEL), and the Rocky Flats Environmental Technology Site (RFETS). These are three of more than 23 sites nationwide where transuranic waste is temporarily stored. During the expected 35-year operating life of WIPP, the Department will transport some 36,000 cubic meters of transuranic waste from 23 locations nationwide. Significant accomplishments during 1999 include:

- On March 26, the Department safely transported the first shipment of defensegenerated non-mixed transuranic radioactive waste from LANL. The historic moment represented the beginning of fulfilling the Department's promise to safely clean up the nation's Cold War legacy of nuclear waste and protect the generations to come. Between the March shipment and November 1999, sixteen additional LANL transuranic waste shipments safely arrived at WIPP for a total of 101 Standard Waste Boxes for permanent disposal. 
- $\quad$ On April 28, the Department safely transported the first shipment of defensegenerated transuranic radioactive waste from INEEL. The first INEEL shipment, an important milestone for the Department and the state of Idaho, consisted of 42 drums of non-mixed waste. Between the April shipment and November 1999, three additional INEEL transuranic waste shipments safely arrived at WIPP for a total of 126 drums for permanent disposal.

- On June 15, the Department safely transported the first shipment of defensegenerated transuranic radioactive waste from RFETS. The first shipment consisted of 26 drums of non-mixed waste. Between the June shipment and November 1999, 22 additional RFETS transuranic waste shipments safely arrived at the WIPP for a total of 600 drums for permanent disposal. RFETS will ultimately send about 2,000 shipments of transuranic waste to WIPP between now and the completion of the site's cleanup.

Early in fiscal year 1999, two important safety initiatives were set in motion ensuring that WIPP would continue operating as a world class safety facility. The ISMS was fully implemented 18 months ahead of the Department's September 2000 goal for all Department of Energy sites. In April 1999, Department and Westinghouse, the Managing and Operating Contractor for WIPP, signed the first Authorization Agreement (AA) for the facility. The AA systematically integrates new safety performance indicators and terms and conditions for management and work practices at all Managing and Operating Contractor organization levels to ensure WIPP will be operated in compliance with the current Standards/Requirements Identification Document (S/RID).

\section{Criticality Safety}

Criticality safety is protection from the consequences of a criticality accident, preferably by prevention of the accident. Criticality safety encompasses procedures, training, and other precautions in addition to physical protection. Where operations involve significant quantities of fissile material, accidental criticality is a hazard for which analysis must be performed and controls must be identified and implemented. The Department recognizes that identifying and analyzing credible accident scenarios and implementing appropriate controls to prevent or mitigate an accidental criticality must involve an efficient process that does not use excessive resources and that allows work to be safely accomplished in a timely manner.

The Department's ongoing criticality safety activities were initiated under the Nuclear Criticality Predictability Program (commenced in 1996) and are now subsumed under the implementation plan for Board recommendation 97-2. The Department's Nuclear Criticality Safety Program establishes an infrastructure to address nuclear criticality needs. The program consists of seven elements: nuclear data, analytical methods, experiments, 
benchmarking, training, nuclear criticality information preservation and dissemination, and extending applicable ranges of bounding curves and data. These elements preserve criticality experiment capabilities and provide data and numerical methods vital to current and future Departmental missions. The Nuclear Criticality Safety Program five-year plan issued in August 1999 describes these elements in detail.

The five-year plan was developed as part of the activities under the Department's implementation plan for Board recommendation 97-2. Other implementation plan activities include:

- Improving the technical knowledge of Federal and contractor criticality safety personnel. In September 1999, the Department published DOE-STD-1135-99, Guidance for Nuclear Criticality Safety Engineer Training and Qualification for contractor employees. In October 1999, a criticality safety qualification standard for Federal employees was published within the Federal Technical Qualification Program.

- Improving the availability and use of criticality safety information and guidance. Criticality safety web sites at DOE (http://tis.eh.doe.gov/criticality/index.html) and Lawrence Livermore National Laboratory (http://ncsc.llnl.gov:8080/) are fully functional and serve as primary avenues of communicating information to the criticality safety community. Additionally, in September 1999, the Department published DOE-STD-1134-99, Review Guide for Criticality Safety Evaluations, to provide a set of guidelines for use by the Department's criticality safety personnel when reviewing criticality safety evaluations.

- Expanding the training course at the Los Alamos Critical Experiments Facility. An advanced 5-day training course was developed and piloted in August 1999. This course expands the training provided in the original 5-day course, which is a prerequisite for the advanced course. Criticality safety experts from the Department and the Board staff attended the course to provide feedback. Improvements will be incorporated into the next advanced course, which will be provided early this year.

In order to further focus on enhancing criticality safety programs, the Department commenced a criticality safety self-improvement initiative in 1999. The kickoff to this initiative was held in August at a criticality safety workshop for senior field office and contractor line managers. The workshop provided managers with operational lessons learned in criticality safety practices and provided assessment tools to facilitate continuous improvement at facilities where fissile materials are stored, handled, or transported. In November 1999, the Deputy Secretary initiated a series of actions to assess the adequacy of the Department's nuclear criticality safety programs and to identify and implement any needed enhancements; these include: 
- Near-term review of operational criticality safety controls at six key Department facilities, with the results of the review to be forwarded to Secretary Richardson.

- Self-assessments for all facilities and operations involving fissile material. Completion of these assessments is scheduled for May 2000.

- Develop performance metrics that are specific to nuclear criticality safety at their sites for incorporation into their contract.

\section{Management Structure Reorganization}

In April 1999, Secretary Richardson announced changes to the Department's organization and management structure that eliminate multiple reporting channels and improve lines of communication, direction, and accountability. The changes include direct-reporting of the Department's major operations and field offices to one of three headquarters program offices, as follows:

- $\quad$ Albuquerque and Nevada operations offices report to Defense Programs

- $\quad$ Oakland, Chicago and Oak Ridge operations offices report to the Office of Science

- Idaho, Savannah River and Richland operations offices, Ohio and Rocky Flats field offices, and the Office of River Protection (in Richland) report to Environmental Management

Headquarters program offices are responsible for site integration and operations; field managers continue to be responsible for day-to-day site program execution, operations, and contract management.

In addition, a Field Management Council (FMC), chaired by Deputy Secretary T. J. Glauthier, was established to assure consistent implementation of Department policy in areas such as environment, safety and health, safeguards and security, and business management.

These changes were reflected in the Department's Safety Management Functions, Responsibilities, and Authorities Manual, revised in October 1999.

\section{E. Project Management Reform Initiative}

In June 1999, the Department's Chief Operating Officer (COO), Deputy Secretary T. J. Glauthier, announced a Project Management Reform Initiative that calls for establishment of a strong Project Management Capability under the direction of the Department's Chief Financial Officer (CFO). The CFO office will provide leadership in developing and implementing project management tools and methods, and will serve as an independent source of project management information that may be used to hold Department managers 
accountable. The initiative calls for each program office to establish a project management capability within his or her own organization reporting directly to them. As outlined, the Lead Program Secretarial Officers (LPSOs) have control of the selection of project managers for their projects and retain project responsibility.

A COO Watch List has been established and Department personnel responsible for projects may be subject to disciplinary actions. The initial watch list includes 4 projects, which are all of particular interest to the Board:

- $\quad$ Savannah River In-Tank Precipitator (Board Rec. 96-1, In-Tank Precipitation System at Savannah River Site);

- $\quad$ Hanford K-Basins Spent Nuclear Fuels (Board Rec. 94-1, Improved Schedule for Remediation);

- Los Alamos Chemistry and Metallurgy Research Facilities Upgrades (Board Rec. 94-1, Improved Schedule for Remediation); and

- Los Alamos Nuclear Materials Security and Safeguards Upgrades.

The Department and the Board both recognize that project management within the Department can be improved. The influence of non-technical project managers is being carefully scrutinized to ensure that health and safety are preserved as priorities. The overall impact of this initiative is expected to be both increased work productivity and increased safety.

\section{F. Integrated Safety Management}

\section{Implementation Criteria}

In October 1999, the Deputy Secretary established the expectation that each field and program office will report to him on full implementation of Integrated Safety Management (ISM) by the Secretary's target date of September 2000. In December 1999, the first field office, Savannah River Operations Office, reported completion of ISM implementation.

In establishing this reporting requirement, the Deputy Secretary provided the following implementation criteria to guide review and determinations that ISM is fully implemented.

1. Department and contractor organizations have established and are maintaining agreed-upon sets of applicable Requirements and Standards. The Department Head of Contracting Activity (HCA, or Contracting Officer) has incorporated agreed-upon sets of standards into contracts. Department and contractor organizations have demonstrated they have in place a defined, functional, 
configuration management infrastructure to maintain their selected "standards set" (e.g., List A/List B, S/RIDs, "Work Smart" Standards).

2. Department has approved applicable Safety Management System Descriptions. Department element managers have completed ISM Phase I verifications and approved SMS Descriptions for all contractor organizations with primary safety responsibilities and for applicable Department organizations.

3. Department has verified adequate implementation of applicable Safety Management Systems. Department element managers have completed ISM Phase II verifications (or equivalent) and concluded that ISM is adequately implemented by all contracting organizations with primary safety responsibilities and by applicable Department organizations. AA's are in place for Hazard Category $I$ and 2 facilities.

4. Department Functions, Responsibilities and Authorities (FRA) Documents are implemented. Department organizations' roles and responsibilities with respect to ISM are clearly defined in the respective FRA Documents and/or any corresponding "Manuals of Practice."

5. Department has verified that Feedback and Improvement Programs are in place and effective. The Department organizations have verified that applicable contractor and Department organizations have effectively implemented: (a) self-assessment programs, (b) corrective action tracking and resolution processes, (c) lessons learned sharing infrastructure, and (d) an overall feedback program leading toward continuous improvement:

6. Department Line Oversight Programs are in place and effective. The Department organizations have developed and implemented a documented, functional line oversight program for evaluating performance relative to ISM principles and functions, in accordance with DOE P 450.5.

7. Department has established a documented process to maintain applicable Safety Management Systems. Department organizations have documented and established a functioning infrastructure to provide annual update direction and to review annual updates and revisions to SMS Descriptions for all contracting organizations with primary safety responsibilities and for applicable Department organizations.

Field Implementation Activities 
Highlights of safety management implementation activities in 1999 are summarized below by the responsible Operations or Field Office for these and other facilities across the Department's defense nuclear facilities complex.

Albuquerque Operations Office (DOE-AL). Implementation of ISM at DOE-AL sites continued to progress during 1999. Below are highlights for the Pantex Plant, Sandia National Laboratory, Los Alamos National Laboratory, and the Kansas City Plant.

Pantex Plant. Mason \& Hanger Corporation (MHC) continues to close out recommendations and opportunities for improvement identified in the 1998 ISM verification. Approximately 75 percent of the recommendations have been closed and closure packages have been submitted for the remainder. Approximately 56 percent of the opportunities for improvement have been closed. All of the Phase $I$ issues are expected to be closed before the Phase I reverification tentatively scheduled for April 2000. A Master AA covering all Category 2 nuclear operations has been developed and approved.

Ten Standards/Requirements Identification Documents (S/RIDs) have been approved at Pantex: Management Integration and Controls S/RID, Radiation Protection and Occupational Safety and Health, Fire Protection, and Nuclear Criticality Sections of the Hazards Control S/RID, and the Emergency Management, Facility Engineering and Construction, Environmental Management, Maintenance Sections of the Mission Support S/RID, and the Off-Site Packaging and Transportation section of the Hazards Control S/RID. An On-Site Packaging and Transportation S/RID section of the Hazards Control S/RID, that includes elements of a Transportation Safety Document, is being developed.

Sandia National Laboratory (SNL). The Albuquerque Operations Office conducted an ISM verification of SNL October-November 1998. By December 1998, SNL had corrected specific recommendations and opportunities for improvements, allowing the Manager, DOE-AL, to approve SNL's ISM System Description. SNL continues to close out recommendations and opportunities for improvement identified in the 1998 ISM verification. SNL is developing useful tools and mechanisms to assist with the overall implementation of ISM throughout the laboratory.

Los Alamos National Laboratory (LANL). The Albuquerque Operations Office conducted an ISM verification of LANL during October 1999. The ISM verification recommended approval of the ISM system description at LANL. A few issues were identified regarding Phase II. This verification was unique due to the integration of the contractually-required Special Assessment evaluations into the overall verification process. LANL is aggressively closing out recommendations and opportunities for improvement identified in the 1999 ISMS Verification report. 
Kansas City Plant (KCP). The Albuquerque Operations Office conducted an ISM verification of the KCP during July 1999 . This verification also included a review of FM\&T/AlliedSignal New Mexico facilities. FM\&T/AlliedSignal KCP continues to close out recommendations and opportunities for improvement identified by its 1999 ISMS Verification.

Idaho Operations Office (DOE-ID). The Idaho National Engineering and Environmental Laboratory (INEEL) made excellent progress towards implementing ISM in accordance with DEAR clause 970.5204-2, Integration of.Environment, Safety and Health Into Work Planning and Execution. Key to the excellent progress in ISM implementation was Lockheed Martin Idaho Technologies Company's (LMITCO) efforts in promoting worker involvement through pursuit of STAR status in the Voluntary Protection Program (VPP). In April 1999, LMITCO and the DOE-ID established the initial set of thirty AA's; INEEL successfully completed the site-wide Phase I ISM Verification; and DOE-ID approved the INEEL ISM System Description Document. In June 1999, DOE-ID announced Bechtel BWXT Idaho, LLC (BBWI) as the incoming INEEL management and operations contractor. The BBWI contract included the new DEAR clause 970.5204-86, Conditional Payment of Fee, Profit, or Incentive, and required BBWI to continue to implement the INEEL ISM System, approved in April 1999, thus maintaining the continuity of ISM. In August 1999, DOE-ID issued its own ISM System Description Document, ID Guide 450.E, which explains how the federal workforce implements ISM for federal functions. In September 1999, the Radiological Environmental Sciences Laboratory (RESL), a government owned - government operated facility at INEEL, successfully completed Phase I ISM Verification. Five pilot facilities at INEEL also successfully completed Phase II ISM Verification; all eleven VPP Units achieved STAR Ready status (interim local recognition); and INEEL completed implementation of DOE P 450.5. Idaho plans to complete final Phase II verifications via two separate reviews in March and May 2000, and declare ISM fully implemented in August 2000.

Nevada Operations Office (DOE-NV). DOE-NV has worked to improve documentation and implementation of ISM in preparation for a Phase I ISM verification to be conducted in February 2000. The Phase II assessment is planned for May 2000.

In March 1999, DOE-NV benefitted from an independent review of the Nevada Test Site (NTS) by the Department's Office of Oversight (EH-2). The scope of the review included Defense Programs (DP); DOE-NV; the management and operations contractor - Bechtel Nevada, Inc.; and selected site users and subcontractors. The review provided DOE-NV an independent perspective on the effectiveness of implementation of its ISM systems and mechanisms being established at NTS. The review occurred while those mechanisms were, in some cases, in their early stages of implementation. The independent assessment has served DOE-NV well, as a driving force for improvement in many areas of 
documentation and implementation. DOE- NV established 87 corrective actions to improve documentation and implementation of various systems and mechanisms; these were approved for implementation by DP in July 1999. As of December 1999, 60 of the 87 corrective actions have been completed. Description of these corrective actions and their associated status is maintained in the Department's Corrective Action Tracking System (CATS).

DOE-NV has documented its systems and mechanisms for the integration of safety management, including the following new or revised DOE-NV Directives:

- $\quad$ NV M 111.1X, Functions, Responsibilities, and Authorities

- $\quad$ NV P 450.4A, Safety Management System Policy

- $\quad$ NV M 450.3X, DOE-NV Work Smart Standards

- $\quad$ NV M 412.X1, DOE-NV Real Estate and Operations Control

- NV M 450.X, Authorizations and Activity Agreements for Facilities and Operations

- $\quad$ NV M 220.X, DOE-NV Oversight Management Systems

- $\quad$ NV O 230.X, DOE-NV Lessons Learned

- $\quad$ NV M 252.1-1A, DOE-NV Directives System Manual

Each of DOE-NV's contractors - Bechtel Nevada Inc., Wachenhut Services, Inc., and IT Corporation - has established ISM system description documents in accordance with contract requirements. These description documents, and the systems and mechanisms they describe, will be evaluated by a Team of experts which will make recommendations for approval by the DOE-NV Manager, during the Phase I ISM Verification scheduled to commence on February 28, 2000. These contractors have re-evaluated implementation of their systems and mechanisms and have instituted improvements of their systems and mechanisms in preparation for the Phase I Verification.

The DOE-NV Directive regarding Authorization and Activity Agreements was revised to incorporate DP lessons learned and EH-2 issues and concerns raised by the EH-2 review of DOE-NV. DOE-NV has, or is planning to have, a total of eight Activity Agreements, five of which are of interest to the Board. The facilities of interest to the Board are: the Device Assembly Facility; the U1a Complex, where sub-critical experiments are conducted; the Radioactive Waste Management Sites in Area 5 and Area 3; the Transuranic Waste (TRU) Pad; and the Waste Examination Facility, Area 5. In addition, DOE-NV has established Activity Agreements for the Big Explosive Experiment Facility, Defense Threat Reduction Agency Tunnel Complexes, and the Hazardous Materials Spill Center. As of December 1999, DOE-NV has six Activity Agreements in effect, five are in process of revisions, and one is in process of being developed (TRU Pad). It should be noted that DOE-NV decided to subdivide one of the Activity Agreements, Waste Management Facilities. The Waste 
Management agreement will be replaced by three separate Activity Agreements: one for the Radioactive Waste Management Sites (Areas 5 \& 3), one for the TRU Pad, and one for the Waste Examination Facility.

Oak Ridge Operations Office (DOE-OR). The DOE-OR manager has placed significant emphasis on ISM, particularly on the active involvement of workers at all levels and in all aspects of the work process. On September 9, 1999, the Manager issued guidance and expectations for ISM, in which great emphasis is placed on worker involvement as the "eighth principle" of ISM.

DOE-OR has 12 major prime contracts into which the ISM-related DEAR Clause has been incorporated.

- Lockheed Martin Energy Systems, Inc. (for operation of Y-12 Plant)

- $\quad$ Lockheed Martin Energy Research Corporation (for operation of Oak Ridge National Laboratory (ORNL))

- Bechtel Jacobs Company, LLC (for management and integration of Environmental Management/Uranium Enrichment work)

- BNFL Inc (for metal recycle and Decontamination and Decommissioning (D\&D) of three buildings)

- Southeastern Universities Research Association (for operation of Thomas Jefferson National Accelerator Facility (TJNAF))

- $\quad$ MK-Ferguson (for project management of the Weldon Springs Site Remedial Action Project)

- Foster Wheeler Environmental (for design, construction, operation and D\&D of a TRU waste facility)

- $\quad$ Decon Recovery Services (for D\&D of Building K-1420)

- $\quad$ Oak Ridge Associated Universities (to operate the Oak Ridge Institute for Science and Education (ORISE))

- $\quad$ East Tennessee Mechanical Contractors (for operation of water plant and provision of maintenance services on the Oak Ridge Reservation)

- $\quad$ East Tennessee Materials \& Energy Corp (for D\&D of building K-1200)

- Wackenhut, Inc. - Oak Ridge (to provide protective services in all of Oak Ridge)

All contractors (except for the contract just awarded to Wackenhut of Tennessee in late November 1999), have developed and submitted ISM System Descriptions. ISM System Descriptions have been approved for four contractors:

- $\quad$ Lockheed Martin Energy Systems, Inc. (approved in October 1998)

- $\quad$ Lockheed Martin Energy Research, Inc. (approved in December 1998)

- $\quad$ Southeastern Universities Research Association (approved in May 1999)

- $\quad$ MK-Ferguson (approved in March 1999) 
In 1999, DOE-OR decided to require AA's not only for all Nuclear Category 1 and 2 facilities, and possibly some Nuclear Category 3 facilities, but also for all High and Moderate Hazard non-nuclear facilities. As of December 1999, DOE-OR has identified a total of $141 \mathrm{AA}$ 's that will be required (1 Cat 1,70 Cat 2,2 Cat 3, and $67 \mathrm{High} / \mathrm{Mod} \mathrm{Non-}$ nuclear). Of that number, 10 have been approved. DOE-OR is working on scheduling the balance for submittal to assure timely completion and approval of these AA's. DOE-OR plans to complete all required AA's in CY2000.

DOE-OR has in place an ES\&H oversight program that addresses the elements in DOE Policy P 450.5, Line ES\&H Self-Assessment. DOE-OR is working on improvement plans to achieve a more effective program. Elements currently in place include:

- $\quad$ Each DOE-OR line organization has implemented an operational awareness program that performs oversight of contractor activities.

- $\quad$ Each DOE-OR line organization with Nuclear Facilities has qualified facility representatives in place to oversee contractor performance on a day-to-day basis.

- Critical Outcomes, ES\&H expectations, and other performance measures have been agreed upon between the line organizations and their contractors.

- $\quad$ Each DOE-OR line organization is responsible for conducting periodic management assessments of their contractor's ES\&H performance.

- $\quad$ Each DOE-OR line organization is responsible for tracking and closing identified corrective actions.

- DOE-OR has fully participated in the CATS database to include all issues identified by the independent oversight activities of $\mathrm{EH}$.

The following improvements are in development:

- A revised DOE-OR Order to better define roles and responsibility of the line organizations and the central ES\&H and Quality Assurance (ESH\&QA) organization is scheduled for issuance in January 2000.

- Establishment of an Issues Management System to keep Senior DOE-OR Management apprised of the significant ES\&H issues that exist within DOE-OR is scheduled for implementation in January 2000.

- Establishment of a separate assessment team within the central ESH\&QA organization to conduct critical self-assessment activities on behalf of the Manager is scheduled to be implemented in First Quarter CY2000.

- Establishment of a central DOE-OR Corrective Action Tracking database system to be used by DOE-OR organizations to improve information flow to management and to better link contractor actions, DOE-OR actions and the EH CATS database, is scheduled to be implemented by the end of Second Quarter CY2000. 
Six ISM verification reviews have been completed at Oak Ridge:

- Lockheed Martin Energy Systems, combined Phase I/I verification (completed August 1998)

- $\quad$ MK-Ferguson, combined Phase I/II verification (completed February 1999)

- $\quad$ Lockheed Martin Energy Research, Phase I'verification (completed May 1999)

- Southeastern Universities Research Association, Phase I verification (completed March 1999)

- Oak Ridge Associated Universities, Phase I verification (completed November 1999)

- Southeastern Universities Research Association, Phase II verification (completed November 1999).

DOE-OR plans to complete Phase I and II verifications for the balance of contracts no later than September 30,2000, with two exceptions that have been reviewed by the Office of Science (SC), the Lead Program Secretarial Office for Oak Ridge.

The first exception is the contract with Foster Wheeler Environmental (FWE), to design, construct, operate and D\&D a TRU waste facility. The strategy for ISM verification on this contract is to review FWE in phases tied to the schedule for the project. The first review, a combined Phase I and II review for design only, will occur in early 2000 . The next review, a Phase II review of implementation during construction, will occur during the initial phase of construction. Phase.II review of operations, and then of D\&D, will likewise occur at the logical future time.

The other exception is for the contract just signed with Wackenhut Services, Incorporated Oak Ridge to provide protective services in Oak Ridge. This contract does not become active until mid-January 2000. Actual schedules have not yet been established, but it is anticipated that Wackenhut will be prepared for a Phase I verification in the fall of 2000. Phase II verification will follow sometime after that.

DOE-OR has seen a steady improvement in safety performance as ISM implementation takes hold. It is expected that this improvement trend will continue as the contractor's management systems mature.

DOE-OR is preparing to conduct a self-assessment of all DOE-OR line and support organizations against the implementation criteria issued by the Deputy Secretary in late October 1999. This self-assessment will be completed in January 2000, and will identify 
any gaps that need to be addressed within the DOE-OR organizations. Each organization will establish plans to improve their systems to close the identified gaps to the satisfaction of the Manager. This will then serve as part of the basis for the Manager to have confidence in certifying full implementation of ISM.

Oakland Operations Office (DOE-OAK). Significant progress has been made at the DOE-OAK with respect to ISM. Both the Stanford Linear Accelerator Center (SLAC) and the E.O. Lawrence Berkeley National Laboratory (LBNL) completed their Phase II verifications during October 1999 and July 1999, respectively. Both the DOE-OAK Stanford Site and the DOE-OAK Berkeley Site Office also led their own verifications with support from DOE Headquarters (HQ) and other subject matter experts.

A combined Phase I/II verification of the Superblock facilities at LLNL was completed during September 1999. Superblock contains the Plutonium Facility (a priority facility), the tritium facility and the Hardened Engineering Test Facility. A majority of the corrective actions identified by this verification will be completed by April 2000 . Key items noted from that verification include reconciliation of the Superblock system description with LLNL Institutional description and conversion to the new Work Smart Standards (WSS) Set. WSS were developed and added to the UC/LLNL Contract on August 5, 1999.

During November and early December 1999, the initial verification of the LLNL Institution was completed. The LLNL system description originally submitted December 1998 was revised and submitted prior to the initial Institutional Verification. The initial Institutional Verification looked at documentation including the LLNL Environment, Safety and Health Manual and the LLNL System Description from the Director through the Associate Directorate levels. Implementation of ISMS was also evaluated for these levels of the LLNL organization. The verification report recommended that the Institutional System Description be approved after completing actions identified by DOE-OAK and continued management focus on the ES\&H Manual is necessary. Also important for LLNL was to continue progress towards transitioning from an expert to standards based system.

Documentation and flowdown of requirements to the LLNL facility level and implementation of ISMS at these lower levels will be evaluated in subsequent verifications. The strategy for conducting the remaining reviews is under development at DOE-OAK. The remaining portions to be verified are scheduled for April/May 2000.

Also other related ISM progress at LLNL includes inclusion of a performance measure for ISM in the UC/LLNL contract for FY2000. During FY1999, AA's were renewed for three LLNL nuclear facilities (Tritium Facility, Plutonium Facility and the Hardened 
Engineering Test Facility). The DOE-OAK Livermore Site Office also developed a system description in preparation for the Superblock and Institutional Verifications that describe the documents, processes, and mechanisms in terms of ISMS for oversight of LLNL.

DOE-OAK plans to declare completion of ISM implementation at all of its sites by June 2000 .

Ohio Field Office (DOE-OH). Significant progress in implementing ISM has been realized by the DOE-OH projects during 1999. DOE-OH has incorporated ISM-related DEAR clauses in the West Valley, Mound, and Fernald contracts. The Request for Proposal for the Fernald contract, which will be completed in late FY2000, will also incorporate these DEAR clauses.

A combined Phase I/II verification was conducted at Fernald in April 1999. Three deficiencies were identified during the review, and the project developed a corrective action plan to address the identified weaknesses. An in-depth Fernald self-assessment was performed prior to Fernald requesting the follow up ISM verification(s). The follow up Phase I verification was conducted in November 1999. No deficiencies were identified and the DOE-OH Manager approved the Fernald Project SMS Description in November 1999. A Phase II verification was conducted at Fernald in December 1999. No deficiencies were identified and it is anticipated that in January 2000 the DOE-OH Manager will approve the determination that ISM is implemented at Fernald. A Phase I verification was conducted at the Mound Site in September 1999, and the DOE-OH Manager approved the Mound System Description in October 1999.

The Miamisburg Environmental Management Project (MEMP) Phase I ISMV was successfully completed in September 1999. Phase II verification is planned to occur in March 2000. With sustained management commitment in safety management, MEMP continues to provide management leadership and direction for ISM implementation, and to maintain a strong management commitment and involvement in the principles and functions of ISM across the Mound Site. A Phase II verification at Mound is scheduled for May 2000.

Office of River Protection (ORP) and Richland Operations Office (DOE-RL). Progress continues with the development and implementation of ISM at the Hanford Site. During 1999, ISM verifications were planned and conducted at the two Hanford Site priority facilities (River Protection Project and Spent Nuclear Fuel Project) and for the institutional/company level safety management system of Fluor Daniel Hanford, Inc. (FDH). Three additional project/company ISM verifications are scheduled for FY2000. During 1999, AA's were prepared and approved for the Reduction Oxidation (REDOX) 
facility, Plutonium Finishing Plant (PFP), and the Waste Encapsulation and Storage Facility (WESF). AA's for the remaining Category II facilities are expected to be completed and approved by no later than June 2000.

In August 1999, an ISM Phase II verification of the River Protection Project (formerly known as the Tank Waste Remediation System) was performed. The verification team concluded that ISM was implemented; however, concerns regarding maintenance of effective ISM during contract and program transitions from DOE-RL/FDH to the ORP/Lockheed Martin Hanford Company (LMHC), and more recently from LMHC to $\mathrm{CH}(2) \mathrm{M}$ Hill Hanford Group, Inc. CHG), would require formal examination. The new prime contract between ORP and LMHC (soon to be CHG) contains language sharply focused on ISM for Environment, Safety and Health, and Quality (ESH\&Q) performance, and includes all ISM-related DEAR clauses. Additionally, LMHC/CHG have been directed by ORP to develop a revised ISM System Description by no later than January 2000. Upon submittal of the ISM System Description, ORP will conduct a management assessment to verify the adequacy of the ISM System Description and its implementation. ORP is also coordinating with the privatized contract Regulatory Unit to ensure ISM is implemented consistent with secretarial ISM related policies. The ORP expects to have completed identified corrective actions and have satisfactorily met the Department's seven ISM Implementation Criteria by May 2000.

In early September 1999, FDH declared readiness for a Phase I verification of the FDH institutional/company level ISM System Description. The verification, which was completed on October 31,1999 , was immediately preceded by a major contract/subcontract restructuring to a project-focused alignment. The verification identified several Noteworthy Practices-as well as a number of Opportunities For Improvement. The verification team concluded that FDH management had made progress in developing an ISM and that, with further clarification of the contract/subcontract restructuring and successful resolution of the Opportunities for Improvement, a fully described ISM System Description could be achieved. As directed by DOE-RL, FDH has developed corrective actions for each of the Opportunities for Improvement. Successful completion of the corrective actions will be verified by DOE-RL prior to approval of the FDH institutional/company level ISM System Description.

In late August 1999, FDH declared readiness for a combined Phase I/II ISM verification at the Spent Nuclear Fuel Project (i.e., K Basins, Canister Storage Building, Cold Vacuum Drying Facility, and Interim Storage Area). The verification, which was completed on November 22, 1999, concluded that while the SNF Project ISMS Description was responsive to the applicable DEAR clauses and Department management direction, four Opportunities for Improvement should be resolved prior to approving the SNF Project ISMS Description as completed and implemented. Specifically, the four Opportunities For 
Improvement highlighted the need to: 1) determine ISM requirements for construction projects; 2) include construction projects in the ISMS Description; 3) define roles and responsibilities during the transition from construction to operations; and 4) complete the development and implementation of a chemical management program. Corrective actions associated with the Opportunities for Improvement are to be submitted to RL, who will verify successful completion. In addition, the SNF Project ISMS Description will need to be reconciled with the FDH institutional/company level ISMS Description following its revision as a result of the FDH Phase I verification described above.

All three ISM verifications identified the Automated Job Hazards Analysis, an institutionalized job hazards analysis tool, as a noteworthy mechanism that ensures worker involvement and supervisory/management engagement in work planning and hazard analysis process. Work associated with the development and implementation of the Automated Job Hazards Analysis and Enhanced Work Planning process began in parallel with other Departmental initiatives, such as, Voluntary Protection Program, ISO 14001 Environmental Management System, Chemical Management Association Responsible Care, and "Work Smart Standards". ISM has been a key driver for accelerating the implementation of several of these initiatives and their integration at the different Hanford Site contractor/project organizations with primary safety responsibilities.

In addition to the Department-sponsored ISM workshops, the Hanford Site held two ISM workshops open to Department and contractor managers, workers, ESH\&Q professionals and Hanford stakeholders. These workshops served as excellent participation/education tools, along with facilitating the commingling of various ESH\&Q forums. A stakeholder representative from the Hanford Advisory Board has also actively participated in each of the three ISMS verifications conducted at Hanford during 1999. This participation has allowed Hanford stakeholders to have a better understanding of the mechanisms in place at Hanford to protect the public, workers and environment.

Rocky Flats Field Office (DOE-RF). Application of ISM principles provide a formal organized process whereby people plan, perform, assess and improve the safe conduct of work. The Integrated Work Control Program (IWCP) is the method by which ISM is implemented on the job. This year, the existing IWCP was upgraded to fully implement ISM principles by providing for improved hazards identification screens, improved feedback mechanisms, and expansion of IWCP usage beyond traditional work activities. The 1999 Department's Office of Oversight Assessment of ISM at DOE-RF concluded "The results of this Oversight Evaluation indicate that DOE-RF and the Kaiser Hill team have established appropriate management systems to achieve continued improvement. With sustained management attention, Rocky Flats Environmental Technology Site is well positioned to achieve full and effective implementation of ISM through the IWCP in a timely manner." While this conclusion indicates that DOE-RF is making significant 


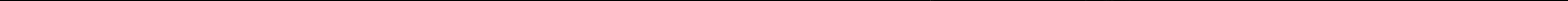


progress, more still needs to be done to achieve full site-wide ISM compliance/implementation. Future improvement actions include conduct of a "floor level" assessment of ISM effectiveness and IWCP understanding and compliance, strengthening of the Standards Management Program, and establishment of ISM performance indicators.

Savannah River Operations Office (DOE-SR). ISM is fully implemented at the Savannah River Site (SRS) and is currently in a mode of maintenance and continuous improvement. All verification reviews have been completed and appropriate AA's are in place. The Westinghouse Savannah River Company (WSRC) independent oversight function continues to routinely monitor implementation of ISM in facilities and programs through the conduct of ISM evaluations, with periodic oversight by DOE-SR. Also, sitewide performance indicators are being measured regularly and actions are taken to enhance improvement where indicated. In addition, the Department's Office of Oversight performed a focused ISM review at Savannah River during 1999 and found that an effective ISM system is being implemented, resulting in improved work processes and sustained safety performance. Issues in the area of hazard analysis are being managed through a new site-wide corrective action process in accordance with the provisions of Board recommendation 98-1. As part of the maintenance and continuous improvement posture, WSRC has implemented a series of actions in support of an ISM Strategic Plan, and is currently revising the Strategic Plan for 2000 and beyond. The ISMS Description Document is maintained current with routine annual reviews and changes, as necessary. An ISM Executive Steering Committee continues to provide senior management leadership and direction for ISM implementation, and maintain a strong management commitment and involvement to the principles and functions of ISM across the site. In the interest of enhancing effective ISM implementation throughout the Department complex, the SRS sponsored a Department-wide workshop on lessons learned in the area of feedback and improvement.

\section{IMPLEMENTATION OF BOARD RECOMMENDATIONS}

\section{A. Recommendation Closures}

The entire process of opening, acknowledging, addressing, resolving, and closing Board recommendations provides a model for safety oversight processes used in various organizations and at various levels throughout the Department's nuclear complex. The manner in which the Department management acknowledges, addresses, and resolves Board safety issues provides an example throughout the Department. Similarly, the manner in which the Board opens safety issues, evaluates resolution approaches, monitors implementation, and ultimately closes safety issues also sets a tone for Department and 
contractor safety oversight organizations. To be effective, these processes must be understandable and predictable.

When a safety issue is identified by an oversight organization for special attention, there is a tendency to reduce line management control over the resolution of the issue by providing additional management direction and organizational support and advice. For example, additional Department headquarters personnel typically get involved and provide direction to the field for implementation. This can conflict with the guiding safety principle that safety is best served through strong line management ownership which integrates safety into normal work processes at the working level. The more quickly that ownership of safety issues is fully integrated into normal line management functions at the working level, the better for safety.

Safety oversight processes which periodically open safety issues and then routinely close them upon substantial resolution serve safety by supporting line management's responsibility for and ownership of safety issues. A routine and orderly process for opening, resolving, and closing safety issues serves safety by reinforcing the concepts of openness to improvement opportunities, addressing safety issues when identified, and strong line management ownership of safety. Similarly, closure of Board recommendations is beneficial to safety when the fundamental safety issues are acknowledged and addressed, the resolution approach is appropriate, the resolution is substantially on target and achieving results, and the organizations and systems are sufficiently mature to integrate continued implementation into ongoing activities. A predictable process for opening, resolving, and closing Board recommendations is also consistent with the original Congressional intent for completion of implementation plans within a relatively short period of time, such as one year. Continued oversight and monitoring is expected on closed Board recommendations to ensure that safety programs and resolutions continue to be implemented as needed. If implementation were to degrade, the safety issue would demand renewed management attention.

Department activities culminating in 1999 led to proposed closure of the following Board recommendations:

- $\quad$ Recommendation 95-1, Improved Safety of Cylinders Containing Depleted Uranium

- Recommendation 94-5, Integration of Department of Energy Safety Rules, Orders, and Other Requirements

- Recommendation 94-4, Deficiencies in Criticality Safety at Oak Ridge Y-12 Plant

- $\quad$ Recommendation 94-3, Rocky Flats Seismic and Systems Safety

- Recommendation 94-2, Conformance with Safety Standards at Low-Level Nuclear Waste and Disposal Sites 
- Recommendation 93-6, Maintaining Access to Nuclear Weapons Expertise in the Defense Nuclear Facilities Complex

- Recommendation 93-5, Tank Waste Characterization Studies

- $\quad$ Recommendation 93-3, Improving Technical Capability in Defense Nuclear Programs

- $\quad$ Recommendation 93-1, Standards Utilization in Defense Nuclear Facilities

\section{Recommendation 95-1, Improved Safety of Cylinders Containing Depleted Uranium}

Recommendation 95-1 identifies the Board's concerns about the storage conditions and plans for long-term management of depleted uranium hexafluoride at Portsmouth, Ohio; Paducah, Kentucky; and Oak Ridge, Tennessee. The Department is storing nearly 700,000 metric tons of depleted uranium hexafluoride in solid form in nearly 56,000 steel cylinders at the three gaseous diffusion plants. The recommendation calls for: 1) repainting or recoating the cylinders, 2) implementing protective measures to prevent future damage or corrosion, and 3) considering a study on alternative chemical forms for the long-term storage of the depleted uranium.

The Department had initiated a program in 1992 to ensure the safety of the long-term storage of depleted uranium hexafluoride. The Department's response to the Board's recommendation was to improve the cylinder management program through a systems engineering approach to risk management. These improvements were developed and instituted concurrently with program activities that were underway. The Department also evaluated, in the safety analysis reports, the adequacy of the safety basis for continued cylinder management, and considered the need for a study on alternative chemical forms for long-term storage of the depleted uranium. After that evaluation, the Department informed the Board that the safety basis was adequate for continued storage, and that such a study was, therefore, unnecessary. The steps in the systems engineering approach to risk management were completed with the final implementation plan commitments delivered on schedule in 1997. Significant accomplishments in 1999 are:

- A subcontract for additional yard reconstruction at Paducah was awarded in 1999 with the base award being completed in late 1999. A subcontract of new yard construction was awarded at Portsmouth with subcontractor mobilizing in 1999. These construction activities are part of on-going improvements for the storage of cylinders.

- A systems engineering requirements analysis was revised to verify the technical rationale for continued cylinder painting in light of depleted uranium hexafluoride conversion being operational in 2005 . 
- In response to Public Law 105-204, the Department submitted a plan to Congress to construct and operate chemical conversion facilities at the Paducah and Portsmouth Gaseous Diffusion Plants. This plan will continue to address the Board's concerns with long-term management of the inventory.

- The Department issued an Expression of Interest and Draft Request for Proposals soliciting feedback from industry on depleted uranium hexafluoride conversion.

- As a result of the privatization of the United States Enrichment Corporation (USEC), the Department continues to accept a few hundred cylinders containing depleted uranium annually. The agreement to accept these cylinders was based on receiving USEC funding to place these cylinders in a configuration compliant with the systems engineering approach implemented in response to recommendation 95-1.

Maintaining the cylinders and improving their storage condition is a multi-year activity. The systems engineering documents delivered to the Board require the construction of additional new cylinder yards, the reconstruction of additional existing cylinder yards, the restacking of cylinders to facilitate inspection and reduce exposure to moisture, and the recoating of cylinders to reduce the rate of external corrosion. Major elements of these tasks will be completed after the year 2000. Some elements, such as inspection, surveillance, yard maintenance, recoating and spot-painting, will continue as long as the Department stores cylinders containing the depleted uranium hexafluoride.

The Department's 95-1 implementation plan required more than one year to complete due to the magnitude of the Department's actions and the deliberate, systems approach employed to establish and implement handling and storage solutions. The final commitment of this implementation plan (approved safety analysis reports on the technical adequacy of depleted uranium hexafluoride storage) was completed in March 1997. The Department continues to update the systems engineering documents that govern cylinder management activities. In particular, the Cylinder Management Program Plan was updated to reflect revised FY1999 and forecasted budgets and accomplishments. The Board closed the recommendation on December 16, 1999, noting the Department's use of the systems engineering process to develop a workable and technically justifiable cylinder management program. The Board indicated in their letter that they will continue to monitor the long-term storage of the cylinders and the eventual conversion of the depleted uranium hexafluoride to a stable form.

Recommendation 94-5, Integration of Department of Energy Safety Rules, Orders, and Other Requirements 
This recommendation suggests that further Department actions were needed to ensure there is no relaxation of plans made to achieve compliance with requirements of Department safety orders while new, streamlined orders were issued and proposed safety rules were under development. In September of 1996, the Board concluded that the orders of interest to the Board were successfully mapped to revised Department orders and proposed safety rules. Other major accomplishments included the completion of crosswalks of requirements from the old safety orders to the new safety orders, and the development of policy statements DOE P 450.2, "Implementation and Compliance with Environment, Safety and Health Requirements," and DOE P 410.1, "Promulgating Nuclear Safety Requirements."

The Department's mechanisms for establishing and integrating safety requirements have significantly matured and strengthened since 1994 . The objectives stated in the Department's October 1994 report and the Board's December 1994 recommendation have been and continue to be implemented:

- The Department has established and is implementing a standards-based safety management system. The ISMS, established in April 1996, provides the overall framework for establishing and implementing safety requirements for both Department employees and contractors. DOE Policy P 450.4, Safety Management System Policy, and DOE Guide G 450.4-1, Safety Management System Guide, define the Department's program.

- Environment, safety and health requirements are established for Department personnel primarily through Department directives (policies, notices, orders, manuals). Appendix A provides a listing of Department directives that include environment, safety and health requirements and are therefore "of interest" to the Board. The Board continues to review all revisions and upgrades to Department directives prior to issuance.

- Responsibilities and processes for maintaining Department directives current and applicable have been established by DOE Order 251.1A, Directives System Order, and DOE Manual M 251.1-1A, Directives System Manual. These processes are in place and functioning effectively. The Directives System, managed by the Office of Management and Administration, calls for the Office of Primary Interest (EH for most of the safety directives) to solicit and resolve comments from line and field offices prior to finalizing directives. Beginning in April 1999, the Deputy Secretary's Field Management Council (FMC), made up of the Department's senior managers, has taken a more active role in approving all additions, changes, and deletions to the Department's system of directives.

- DOE Manual 411.1-1A, Safety Management Functions, Responsibilities, and Authorities Manual (or FRAM) provides the corporate-level, integrating mechanism for defining Department roles and responsibilities in fulfilling safety 
requirements. The FRAM was most recently revised and updated in October 1999.

- $\quad$ DEAR Clauses 970.5204-78 (Laws, regulations, and Department directives) and 970.5204-2 (Integration of ES\&H into work planning and execution) establish the contractual framework for establishing and enforcing safety requirements. These clauses were established in June 1997 and fully implemented in all major contracts by May 1998.

- $\quad$ Environment, safety and health requirements are established and integrated for Department contractors via their contracts, which include both a List of Applicable Laws and Regulations (List A) and a List of Applicable Directives (List B). These lists are periodically reviewed and updated to maintain them complete and applicable.

- The effectiveness of processes for establishing contractor safety requirements are being reviewed by ISMS Phase 1 verifications. The effectiveness of implementation of these requirements is being reviewed by ISMS Phase II verifications. ISMS verifications are ongoing and scheduled for completion by September 2000.

- The Department continues to make progress in converting a limited set of upper-level safety requirements for contractors into rules. To meet its statutory mandate to enforce violations of nuclear safety requirements (as required by the Price-Anderson Amendments Act (PAAA) which amended the Atomic Energy Act (AEA), Department has issued final or proposed nuclear safety rules (or PAAA rules) in four parts:

- $\quad 10$ Code of Federal Regulations (CFR) Part 820, "Procedural Rules of DOE Nuclear Activities;"

- $\quad 10$ CFR Part 830, "Nuclear Safety Management Rules;"

- $\quad 10$ CFR Part 834, "Radiation Protection of the Public and the Environment;" and

- $\quad 10$ CFR Part 835, "Occupational Radiation Protection."

The Department is currently evaluating additions to the Part 830 safety management rules. The net effect of converting safety requirements into rules is: 1) the requirements are moved from List $B$ to List $A$ in the contract, and 2) violations of nuclear safety requirements are subject to PAAA enforcement, including the imposition of civil and criminal penalties, in addition to contract enforcement and penalties. The overall framework for establishing and implementing safety requirements provides adequate flexibility and responsiveness to accommodate additions and changes to safety requirements. 
In the Department's 1996 Annual Report to Congress, issued February 1997, the Department concluded that the objectives of this recommendation had been accomplished, it was ready for closure, and any ongoing actions could be tracked and completed under the Department's implementation plan for ISM. On June 10, 1999, the Board closed this recommendation, agreeing that any remaining open issues are adequately covered by the provisions for implementing ISM.

\section{Recommendation 94-4, Deficiencies in Criticality Safety at Oak Ridge Y-12 Plant}

Recommendation 94-4 summarizes the Board's concern with criticality safety and conduct of operations at the Y-12 Facility at Oak Ridge. The recommendation acknowledges that the Department and its contractor have taken steps to correct deficiencies, and encourages more aggressive and comprehensive management actions.

The 94-4 implementation plan presented a schedule of near-term actions to support the Y-12 resumption effort. The plan also presented a path of programmatic improvements to assure the achievement of an adequate level of safety at Y-12 over the long-term.

The implementation plan includes assessments of the level of conduct of operations at $Y-12$, reviews of personnel training, and compliance evaluations on operational safety requirements, criticality safety analyses, and operating procedure controls. The Department is using operational readiness reviews and readiness assessments, conducted by senior technical managers augmented as necessary by independent experts, to ensure that needed program improvements and culture changes are institutionalized.

The 94-4 implementation plan required more than one year to implement due to the magnitude of the Department's actions involved and the required changes to the safety culture. On February 17, 1999, the Department proposed closure of the recommendation to the Board based upon successful completion of implementation plan efforts and the restart activities that had been completed to that point. The implementation plan had guided improvements in criticality safety, training and qualification, and conduct of operations at the Y-12 Plant. Additionally, as a direct result of execution of the Department's plan, process improvements and increased efficiencies were observed, which allowed $Y-12$ to meet or exceed production expectations. Therefore, the Board closed the recommendation in a letter to the Secretary on March 12, 1999.

Recommendation 94-3, Rocky Flats Seismic and Systems Safety 
Recommendation 94-3 focused the Department on assuring that Rocky Flats' large plutonium inventory is stored in a robustly safe facility. At the time of this recommendation there were uncertainties regarding the capacity of the intended storage facility to resist earthquakes. Rocky Flats is consolidating the site's plutonium into Building 371 pending off-site disposal.

The Department completed its implementation plan commitments to resolve safety questions and plan appropriate safety margin improvements in 1996. Because all actions to upgrade the safety of Building 371 were not then completed, efforts to continue them were managed under a formal Integrated Program Plan. That plan was issued in July 1996 and subsequently revised in June 1998. The revision provided for continuing upgrades until substantial progress in shipping plutonium materials off-site provides assurance that additional expenditures for site interim storage safety are not needed.

These upgrades to Building 371's structure, systems, components, and safety basis were completed in a phased approach with the final phase of safety upgrades relating to a revised safety analysis being completed in 1999. Implementation of additional safety margin upgrades to Building 371 were discontinued since shipping milestones identified in the Integrated Program Plan were being met. On May 27, 1999, the Board formally closed recommendation 94-3 recognizing that the objectives had been met with the completion of the upgrades needed to ensure safe storage of special nuclear material in Building 371 for the near term.

\section{Recommendation 94-2, Conformance with Safety Standards at Low-Level Nuclear Waste and Disposal Sites}

Recommendation 94-2 expressed the Board's concern that the Department's low-level waste management program had not kept pace with the evolution of commercial practices. The Board also noted that no defense nuclear low-level waste disposal facilities had approved radiological performance assessments required by DOE Order 5820.2A, Radioactive Waste Management. The recommendation called for a comprehensive, complex-wide review of low-level waste management, similar to that conducted by the Department on spent fuel. The Board also recommended development of a regularized program of low-level waste disposal needs, issuance of additional requirements and guidance regulating the management of low-level waste, conduct of studies aimed at improving the waste management program, and completion of radiological assessments which account for all contributing source terms of low-level waste disposal facilities. 
During 1999, the Department made good progress on completing the actions in the implementation plan for recommendation 94-2. Accomplishments during 1999 include:

- $\quad$ Completed 65 of the 69 plan milestones through 1999.

- $\quad$ Issued Department Order 435.1, Radioactive Waste Management, on July 9, 1999, which replaced Order 5820.2A of the same title. Accompanying the Order were the Department Manual and Guidance documents. Training courses on implementation of the Order are now in progress. It is expected that some implementation, such as having radioactive waste management basis statements approved and in place for all facilities, may require up through FY2001 to complete. By the end of FY2001, all aspects of the Order are to be fully implemented and completed.

- $\quad$ Completed the Low-Level Waste Management Program Research and Development Implementation Plan on April 8, 1999. The low-level waste research and development strategy has been integrated with the Office of Science and Technology, effectively linked to the budget process, and is being implemented.

- Revised the following guidance documents to ensure consistency with the Department Order 435.1:

- $\quad$ Maintenance Guide for the U.S. Department of Energy Low-Level Waste Disposal Facility Performance Assessments and Composite Analysis,

- $\quad$ Format and Content Guide for U.S. Department of Energy Low-Level Waste Disposal Facility Performance Assessments and Composite Analyses,

- $\quad$ Format and Content Guide for U.S. Department of Energy Low-Level Waste Disposal Facility Closure Plans, and

- $\quad$ Low-Level Waste Federal Review Group Manual.

- The Department issued disposal authorization statements for the following lowlevel waste disposal sites:

- Hanford 200 Area East, 200 Area West and Immobilized Low-Activity Tank Waste,

- $\quad$ Nevada Test Site Area 3,

- $\quad$ Oak Ridge Integrated Waste Management Facility (SWSA 6), and

- Savannah River Site E Area Vaults and Saltstone.

The four remaining deliverables in the implementation plan include issuance of the Idaho National Engineering and Environmental Laboratory Radioactive Waste Management Complex disposal authorization statement, Nevada Operations Office 
submission of the Nevada Test Site Area 5 Composite Analysis, review of the Nevada Test Site Area 5 Composite Analysis, and issuance of the Nevada Test Site Area 5 disposal authorization statement. The Department expects to complete these activities by the end of the CY2000. The Idaho National Engineering and Environmental Laboratory disposal authorization statement is on schedule to be issued by March 2000 . Preparation of the Nevada Test Site Area 5 Composite Analysis is in progress and the disposal authorization statement is scheduled to be issued by December 2000 .

The Department's implementation plan for this recommendation required several years to implement due to the magnitude and complexity of the complex-wide review and improvement to the low-level waste management program including improvements to the Department's program directives. On November 18, 1999, the Department briefed the Board on the closure of recommendation 94-2 based on the progress to-date and the few remaining actions from the implementation plan that are scheduled for completion in 2000. The Department prepared a final progress report, submitted it to the Board, and proposed closure of recommendation 94-2 on December 20, 1999. The Board responded and formally closed the recommendation on December 22, 1999.

\section{Recommendation 93-6, Maintaining Access to Nuclear Weapons Expertise in the Defense Nuclear Facilities Complex}

This recommendation expresses the Board's concern that the unique talents and experience of personnel have been and are being lost from the Department and its weapons complex as a result of changes in the Department's mission and emphasis, and its subsequent downsizing. The recommendation emphasized the need to retain access to, and capture the unique knowledge of, those individuals who have been engaged in weapons assembly, disassembly, and testing activities in order to avoid future safety problems in these areas. Retention of this information contributes to the Department's present and future capability to safely manage and maintain the weapons stockpile and disassemble existing weapons.

The Department completed the implementation plan deliverables by October 1996 and proposed closure of this recommendation in December 1996. The Department met with the Board in January 1997 to discuss completed actions and the path forward to closure. The Board indicated that it wanted to continue to monitor the actions which were started with this recommendation. In February 1999, the Department provided an updated status of information management activity in DP which addressed the Board's remaining issues, and subsequently proposed closure on April 2, 1999. On April 27, 1999, the Board formally closed recommendation 93-6.

\section{Recommendation 93-5, Tank Waste Characterization Studies}


This recommendation noted that technical information on tank wastes was not sufficient to ensure that Hanford Site wastes could be safely stored, that associated operations could be conducted safely, and that future data requirements to support waste disposal could be met. The Board recommended that the Department upgrade and expedite the characterization efforts for the high-level waste tanks at the Hanford Site. This recommendation also called for revision of sampling protocols and expansion of the laboratory capacity. Lastly, this recommendation sought integration of these characterization efforts with other systems engineering tasks.

The original implementation plan encompassed activities for developing a technical basis for characterization and for improving the sampling equipment. This was to be done in parallel with sampling and analyzing all 177 tanks for safety-related reasons by October 1996. The Department realized that tank safety issues could not be resolved solely by accelerating sampling and analysis. During 1996 , this realization led to a major revision of the Department's implementation plan. The revision, transmitted to the Board in June 1996, focused on obtaining a better understanding of the safety-related phenomena, which can lead to safety concerns with the high-level waste tanks. Some of the principal accomplishments for 1999 on the revised implementation plan are as follows.

- The data requirements needed to support characterization were better defined, enabling greater efficiency in determining waste safety. In fiscal year 1999, 74 additional tank characterization samples were drawn and analyzed, bringing the total to 527. Overall tank waste characterization was documented, evaluated and determined adequate to assure the safety of waste storage. Waste safety requirements were implemented as derived in a revised safety basis.

- Statutory direction for clear lines of responsibility for the Office of River Protection, with staffing to support both technical and program management, were implemented in 1999. Contract management for the tank farms operating contractor was simplified and streamlined to clarify responsibility and accountability for the Tank Waste Remediation System program.

- The ISMS (recommendation 95-2) was verified implemented to assure safety of ongoing operations. Six tank safety concerns addressed in the implementation plan were resolved. Sampling and analytic requirements were identified and capacities tailored to provide the needed capabilities for both safety of storage and for safe retrieval and processing of waste. The infrastructure and staff assembled to re-engineer the characterization project remain in place, though analytic facilities employed in support of privatized waste processing will be selected by the privatization contractor. 
The Department's 93-5 implementation plan required more than one year to complete due to the magnitude of the actions required and the time necessary to sample and analyze tank wastes. The Department continues to sample and characterize tanks, as necessary, to support River Protection Project programs such as operations, safety issue resolution, and waste disposal. The Department completed all commitments under its implementation plan as revised, and recommended closure of recommendation $93-5$ by letter of October 29, 1999. On November 15, 1999, the Board formally closed the recommendation.

\section{Recommendation 93-3, Improving Technical Capability in Defense Nuclear Programs}

This recommendation raised concerns regarding the technical capability of the Department's personnel who are responsible for ensuring that safety is maintained at defense nuclear facilities. In the recommendation, the Board described its concerns regarding the Department's difficulty in attracting, developing, and retaining personnel who are adequately qualified by technical education and experience to provide the level and quality of management, direction, and guidance that are essential to the Department's safe operation of its defense nuclear facilities.

In April of 1997, the Department received a letter from the Board that requested an implementation plan revision to delete milestones that were no longer considered to be of value and establish an aggressive but achievable schedule for the new milestones. In response, the Secretary chartered a working group of senior line managers representing each field and program office having safety responsibilities at defense nuclear facilities to revise the Department's 93-3 Implementation Plan. The Secretary submitted the Revised Implementation Plan (Plan) for Improving DOE Technical Capability in Defense Nuclear Facilities Programs to the Board on May 5, 1998, and the Board accepted the revised Plan on June 1, 1998.

The Department, under the leadership of the Federal Technical Capability Panel, made significant progress in completing the commitments in the revised Plan. Significant accomplishments occurred in 1999 in each of the key program elements of the Federal Technical Capability Program (FTCP). These include:

- The Department institutionalized the Federal Technical Capability Panel (Panel). The Panel, which consists of senior managers, reports to the Deputy Secretary and is responsible for overseeing and resolving issues affecting the Department's FTCP. This includes overseeing the Senior Technical Safety Manager (STSM) Program, conducting periodic assessments of the effectiveness of the FTCP using internal and external experts, and providing 
recommendations to senior Departmental officials regarding Department technical capability.

- In April 1999, the Panel issued its first annual report summarizing actions taken during CY1998 to address the Department's hiring and deployment needs for technical personnel whose duties relate to safe operations at defense nuclear facilities.

- The Panel will continue to function in its role of monitoring and overseeing the implementation of the FTCP for the Department. The Panel developed an Annual Plan for FY2000 to guide its activities. These activities encompass the recommendations the Panel made to the Secretary in its Annual Report.

- The FTCP Manual has been drafted and submitted to the Department's Directives system for issuance. This manual institutionalizes those aspects of the program not currently covered by other directives. The Department will then have the following documents in place to ensure institutionalization of the FTCP:

\section{- $\quad$ DOE Policy 426.1 Federal Technical Capability \\ - $\quad$ DOE Order 360.1 Training \\ - DOE Manual 426.X-1 Federal Technical Capability Program \\ - $\quad$ DOE Guide 426.1-1 Manager's Guide to Administrative Flexibilities}

- The Technical Leadership Development Program (TLDP) was reestablished. The TLDP is designed to bring $20-30$ young, highly qualified, and diverse entry level interns into the Department each year. The TLDP consists of a 3 year program of technical and managerial/leadership training, mentoring, rotational assignments, and increasingly responsible work experiences that will ensure that the Department has the caliber of technical employees, and future managers, needed to carry out its defense nuclear related missions. The Office of Human Resources Management has incorporated TLDP requirements in its Corporate Recruitment efforts, and is coordinating national recruitment with local recruitment efforts by the Field Offices.

- $\quad$ Each HQ and field element completed an assessment of the implementation of their Technical Qualification Program. Continuing biennial assessments will be conducted.

- The Secretary has endorsed the Panel's recommendation to pursue the expansion of the current FTCP to include all federal technical capability requirements, not just those associated with the safe operations of defense nuclear facilities. Several offices are expanding the program to include personnel other than those associated with defense nuclear facilities. 
- The technical workforce analyses were completed and used to identify critical technical skills that each Departmental element with defense nuclear facility safety responsibilities must maintain.

In June 1999, the Board requested the Department provide them a report on the status of completing the commitments in the 93-3 Plan, the rationale for closing recommendation 93-3 and the Department's plan for continuing the FTCP. This report was provided on October 13, 1999. On November 9, 1999, the Board formally closed recommendation 93-3.

\section{Recommendation 93-1, Standards Utilization in Defense Nuclear Facilities}

Recommendation 93-1 focuses on ensuring that the level of safety assurance at those facilities that assemble, disassemble, and test nuclear weapons is at least as rigorous as that required at other defense nuclear facilities. The Department's implementation plan calls for identification and modifications of the Department's orders and directives to strengthen the safety assurance for nuclear weapons operations and facilities. The implementation plan also incorporated the recommendations contained in the Nuclear Explosive Safety Study Corrective Action Plan which implemented actions associated with the Board's Nuclear Explosive Safety Study Independent Review.

Implementation of the following provide a level of safety assurance at facilities that assemble, disassemble, and test nuclear weapons comparable to that required for other defense nuclear facilities:

- DOE Order 452.1A "Nuclear Explosive and Weapon Surety Program,"

- DOE Order 452.2A "Safety of Nuclear Explosive Operations,"

- $\quad$ DOE Guide 452.2-1A "Implementation Guide for DOE Order 452.2A Safety of Nuclear Explosive Operations,"

- $\quad$ DOE-Standard (STD)-3015-97, "Nuclear Explosive Safety Study Process,"

- $\quad$ DOE-DP-STD-3016-99, "Hazard Analysis Reports for Nuclear Explosive Operations," and 10 CFR Part 711, "Personnel Assurance Program; Final Rule."

On March 2, 1999, the Department provided the Board with a copy of the directives, implementation guides, technical standards, and public rule described above and proposed closure of the recommendation. On March 25, 1999, the Board formally closed recommendation 93-1.

\section{B. Recommendation Proposed for Closure}


In 1998, the Department completed the last deliverable described in the implementation plan for Board recommendation 92-4, Multi-Function Waste Tank Facility at the Hanford Tank Farms, and proposed closure of the recommendation.

\section{Recommendation 92-4, Multi-Function Waste Tank Facility at the Hanford Tank Farms}

The primary focus of Board recommendation 92-4 was the Tank Waste Remediation System (TWRS) Multi-Function Waste Tank Facility (MWTF) project at the Hanford Site. The recommendation identified three areas of concern: 1) project management structure, 2) design bases (systems engineering) for MWTF, and 3) technical and managerial competence. In developing an implementation plan to address these issues, the Department expanded the scope of its response to apply an integrated systems approach to define, plan, control, and execute the overall Hanford mission. While implementing this approach, the Department reevaluated the need for the MWTF project, canceled the project, and altered other TWRS projects. The Department completed thirty-eight commitments, including all program management and Site systems engineering commitments, in the first implementation plan and all commitments in a revision to the implementation plan.

In 1999, the statutory reorganization which provided for the Office of River Protection (ORP) was fully implemented. With clear lines of authority and accountability within the Department, the Department executed a change to the operating contract for tank farm operations to streamline contract control by the ORP. All River Protection Project (previously TWRS) contracts incorporated requirements for use of the ISMS, and this system's implementation was verified for the operating contractor in 1999.

Headquarters staff were organized to support the line management of this program, which encompasses tank farm operations, waste retrieval, processing and disposal. The combined program was designated as a Strategic System by the Department, with key program decisions made by the Secretary.

One such key decision is scheduled for August 2000, and the program team is prepared to provide information to the Congress to coordinate program decisions with the budget planning basis. The planned decision includes readiness of the department, its operating and privatization contractors to proceed with a cost sharing privatization contract for vitrification process facilities construction and operation. The ORP is developing integrated and resource loaded plans and schedules which identify the integrated multi-contractor baseline and critical path for continuing with the vitrification processing program. Contractor interface control technical documents 
define how efforts are to be coordinated between organizations to achieve success. The ORP is preparing a restructuring of its projects to facilitate better coordination between project management, budget process, and fiscal accountability. These efforts continue to implement clear responsibility and authority, define and coordinate expectations for contractors and the Department in support of program management and regulatory oversight, and to manage the program as a system. The Board was briefed on specific aspects of this integrated effort during a site visit on December 9, 1999.

This implementation plan required more than one year to complete due to the magnitude of applying systems engineering principles to projects at the Hanford Site. The final implementation plan deliverable was completed and provided to the Board in July 1998 and the Department proposed closure of the recommendation in a December 16,1998 , letter to the Board.

\section{New Recommendation and Implementation Plan}

In 1999 the Department accepted one new recommendation received from the Board, recommendation 99-1, Safe Storage of Pits at the Pantex Plant.

\section{Recommendation 99-1. Safe Storage of Pits at the Pantex Plant}

In October 12, 1999, the Department accepted the Board's recommendation 99-1, which addresses issues associated with the safe, long-term storage of pits at the Pantex Plant. The recommendation identifies a need for the Department to expeditiously resolve issues associated with ensuring the long-term safety of pits awaiting return to the strategic stockpile or disposition that would permanently remove plutonium from weapons use.

The Department is currently preparing the implementation plan under the leadership of the Deputy Assistant Secretary for Military Applications and Stockpile Operations, Defense Programs. Since the Board issued recommendation 99-1 in August 1999, the Department has taken actions to address the issues associated with long term pit storage.

- The Department has evaluated the potential for corrosion of capscrews used in the AL-R8 Sealed Insert pit storage container and has determined a replacement capscrew is warranted. Actions have begun to qualify a new replacement capscrew.

- A supplemental pit evaluation effort is being performed on a small number of pits that have been stored in AL-R8 containers at the Pantex Plant for an 
extended period of time. The purpose of this special effort is to better understand the impact of the past and current storage condition on pit quality.

- A container surveillance program has been developed and is currently being updated to include more detailed information on the statistical basis, data that will be collected and how the data will be used.

- $\quad$ Repackaging of pits into the AL-R8 Sealed Insert container began in July 1999. These containers will provide the appropriate environment to help enable safe and reliable storage of pits. Efforts are being made to establish a repackaging rate that will ensure all pits are repackaged within the time frame recommended by the design laboratories to address concerns with the current storage environment.

The implementation plan is due to the Board on January 27, 2000.

\section{Other Active Implementation Plans}

\section{Recommendation 98-2, Safety Management at the Pantex Plant}

The Board issued recommendation 98-2 on September 30, 1998, addressing the need to accelerate safety improvements for nuclear explosive operations at the Pantex Plant. Recommendation 98-2 represents a combination of issues raised in prior Board recommendations and issues identified through more recent staff observations of Pantex activities. The actions undertaken through this implementation plan are aimed at simplifying and standardizing activity level safety management processes for all work involving nuclear explosives at the Pantex Plant.

On April 22, 1999, the Department issued an implementation plan which outlines a comprehensive strategy to ensure practical and timely implementation of safety improvements and tailoring of the Seamless Safety for the $21^{\text {st }}$ Century principles. The key accomplishments during 1999 include:

- Development and Production Manual (AL 56XB) was revised to define and streamline integrated safety (Seamless Safety-21) expectations in order that the operating contractor and design agencies may systematically implement these practices for all nuclear explosives operations at Pantex.

- Issued the Department of Energy Albuquerque Operations Office (AL) Site Directives (SD) 452.1B, Nuclear Explosive and Weapon surety Program and 452.2B, Safety of Nuclear Explosive Operations. The purpose of these Directives is to significantly enhance the Line management safety basis for nuclear explosive operations. The enhanced safety basis will allow the Department's Line management to assert readiness before requesting an 
independent Nuclear Explosive Study (NES) and readiness reviews. This approach allows the NES review to evaluate whether the proposed operations meets the intent of the NES Standards $(452.1 \mathrm{~A} / 1 \mathrm{~B})$ and evaluate whether the approved authorization basis controls are effectively implemented (452.2A/2B).

- $\quad$ Revised DOE-STD-3015, Nuclear Explosive Safety Study Process (NESS). The purpose of this revision is to enhance the NESS Group membership, qualifications and training.

The Department's implementation plan represents an aggressive strategy for improving safety management processes for nuclear explosive operations at the activity level. However, the Department will require more than one year to implement this plan due to the magnitude and scope of the actions.

\section{Recommendation 98-1, Resolution of Department Internal Oversight Findings}

On September 28, 1998, the Board issued recommendation 98-1, which deals with the need for a systematic process for the disposition and resolution of the findings of the Department's internal, independent oversight organization. The Secretary accepted the recommendation on November 20,1998, and established the Department's implementation plan on March 10, 1999. The implementation plan identified specific actions to improve the Department's corrective action process, addressing the following elements: roles and responsibilities, issue/dispute resolution process, senior management involvement, contents of corrective action plans, tracking and reporting, and verification of corrective action effectiveness. The implementation plan is being managed under the direction of the Safety Management Implementation Team Manager.

The key accomplishments in accordance with the Department's implementation plan during 1999 include:

- In March 1999, the Department established and chartered its Integrated Corrective Action Management (I-CAM) Team, which has led and coordinated the Department's efforts on this implementation plan.

- In March and April 1999, the Department established clear direction for line managers to address legacy oversight findings, and communicated these expectations in a Department-wide workshop. In April 1999, the Office of Independent Oversight (EH-2) issued to line managers a summary of over 450 legacy safety issues.

- In June 1999, the Department completed initial development of the Department Corrective Action Tracking System (CATS) and it was accepted by the I-CAM Team for Department-wide implementation and use. 
- In July 1999, the Office of Independent Oversight (EH-2) issued revised protocols to enhance line management understanding of identified safety issues and to clarify expectations of the line for addressing and resolving the identified issues. Department line managers were given ample opportunity to review and comment on the EH-2 protocols.

- In September 1999, the Department line managers effectively completed population of the CATS database with corrective actions for identified legacy safety issues. Line managers prepared corrective action plans or corrective action reports for all identified legacy safety issues and provided CATS data input on corrective actions.

- In October 1999, the Department institutionalized the corrective action processes described in the implementation plan through revisions to the Quality Assurance Order (DOE Order O 414.1) and the Safety Management Functions, Responsibilities, and Authorities Manual (DOE Manual M 411.1-1A).

- In November 1999, the I-CAM Team provided the initial Secretary's Quarterly Report on corrective action status and presented this information to the Deputy Secretary and the Secretarial Safety Council.

- In December 1999, the Department established its verification team and approach for reviewing effectiveness of actions taken under this plan to improve resolution of safety issues.

- The Department provided periodic reports to the Board on implementation plan progress in May 1999, September 1999, and January 2000.

As originally conceived in March 1999, this plan is scheduled for completion by June 2000 and will require a total of more than one year to complete. More than one year is required due to the need to assure that process changes have been adequately implemented and institutionalized as part of the ongoing safety management structure. Key activities in the upcoming year include verification of the effectiveness of process changes, review of the CATS management tool, and expansion of the scope of the corrective action process to include safety issues beyond those identified by the independent oversight organization. The Department continues to anticipate completion by June 2000 , as originally planned.

\section{Recommendation 97-2, Criticality Safety}

The Board issued recommendation 97-2 on May 19, 1997, addressing the effectiveness of criticality safety programs at defense nuclear facilities in the Department complex. This recommendation identified the need to ensure that criticality safety continues to be achieved efficiently in the Department's current and future operations. It represents a continuation and expansion of Board recommendation 93-2, Critical Experiment Capability. 
The Department developed an implementation plan which outlines a comprehensive strategy to improve the efficiency of criticality safety programs within the Department. The key accomplishments related to recommendation 97-2 during 1999 were:

- The Department took steps to preserve important criticality safety related information. Logbooks from closed critical mass laboratories across the country were preserved and are being digitized and archived at Los Alamos. Other unclassified calculations and criticality safety reference materials, such as the Parameter Study Working Group materials, are also being digitized and placed on the web site at Lawrence Livermore National Laboratory.

- Technical knowledge of criticality safety personnel is being improved through expansion of the training course at Los Alamos, development of additional training materials which can be accessed through the web, and development of qualification standards for federal and contractor criticality safety personnel. Federal staff will be qualified according to the standard by December 2000 , and contractors will be required to qualify their criticality safety staff as well.

- A new technical program was initiated to use sensitivity and uncertainty analytical methods to develop tools which can be used by criticality safety practitioners to determine applicable ranges of data for validation of criticality safety evaluations.

- A Departmental guide for reviewing criticality safety evaluations was issued and is intended to enhance consistency and uniformity of these reviews.

The Department's implementation plan represents an aggressive strategy for improving criticality safety programs to ensure efficient support of ongoing fissile material activities. However, the Department will require more than one year to implement this plan due to the magnitude and scope of the actions. The last action te be completed in this implementation plan, qualifying federal staff directly performing criticality safety oversight, is scheduled for December 2000.

\section{Recommendation 97-1, Safe Storage of Uranium-233}

Recommendation 97-1 expressed the Board's concern regarding the safe storage of unirradiated uranium-233 (U-233) at various sites in the Department's complex. The primary safety issue described within the recommendation is the lack of material characterization and uncertainty of storage conditions for U-233. The recommendation had been preceded in February 1997 by a Board technical report entitled "Uranium-233 Storage Safety at Department of Energy Facilities." The report described the Board's perspective of the safety of U-233 stored at various sites in the Department's complex. This formed the basis for the Board's recommendations. The report also acknowledged the Department's Highly Enriched Uranium Vulnerability Assessment completed in 
August 1996. As a result of that assessment, the Department was aware of the legacy issues surrounding the storage of U-233 bearing material. The Department's assessors had come to many of the same conclusions as those described in the Board's technical report. At the time of issuance of recommendation 97-1, the Department had initiated development of a plan describing the necessary corrective actions for the most significant vulnerabilities identified. The Department's Highly Enriched Uranium Vulnerability Management Plan was issued on June 13, 1997.

The Department has an inventory of approximately two metric tons of U-233 in many different forms stored under a variety of conditions throughout the complex. The majority is located at the Oak Ridge National Laboratory and the Idaho National Engineering and Environmental Laboratory, with much smaller quantities at Los Alamos National Laboratory and even smaller quantities at numerous other sites. The material exists in various forms, as oxides, metal, solutions and fluorides.

The Department used a systems engineering approach to manage the implementation of this recommendation as well as to consider long term options for the U-233 inventory such as long term storage, disposition as excess material or possible beneficial use. During the year the Department made considerable progress by completing the remaining commitments of the implementation plan for this recommendation. Some key activities completed in 1999 include:

- $\quad$ Final site assessments of material packaging and storage conditions at Oak Ridge National Laboratory and Los Alamos National Laboratory to ascertain the need for additional remedies to observed shortfalls.

- A technical data book documenting the knowledge base gained through past U-233 operations.

- A report on the consolidation of small sites' holdings at a long-term storage facility.

- $\quad$ Continuing safety evaluations of the U-233 storage vaults in Building 3019 at Oak Ridge.

- Installation of equipment and preparations for the first phase of container inspections in Building 3019 at Oak Ridge.

In addition to the above, in July 1999 the Department completed and delivered the Program Execution Plan to the Board which was the final deliverable under the implementation plan. The Program Execution Plan is a comprehensive, integrated multi-year plan designed to complete resolution of safety concerns referenced by recommendation $97-1$ and provide a long term management strategy for disposition, beneficial use or other decision alternatives relative to the U-233 inventory. It delineates the organization, control system, work breakdown structure, task definitions, 
multi-year schedule, and resources required to safely conduct life-cycle management of the Department's U-233 inventories.

\section{Recommendation 96-1, In-Tank Precipitation System at the Savannah River Site}

The Board issued recommendation 96-1 on August 14, 1996, to address concerns at the In-Tank Precipitation (ITP) facility related to potential generation and release of flammable benzene in the primary process tank. This recommendation identified the need for improved understanding of the mechanisms leading to the generation, retention, and release of benzene, and based on this understanding, evaluation of the adequacy of existing safety measures and deveiopment of additional safety measures as necessary.

ITP is the process step in the vitrification of unstable hazardous radioactive and chemical liquid wastes that precipitates the highly radioactive salt fraction of liquid high-level waste to allow for vitrification of the wastes by the Defense Waste Processing Facility (DWPF). ITP began operations in September 1995, treating the first batch of high-level waste with sodium tetraphenylborate (TPB) to precipitate cesium, and sodium titanate (MST) to adsorb uranium, plutonium and strontium. Following several startup tests, slurry pumps were being operated on December 1 , 1995, prior to sampling the tank, when benzene in quantities greater than expected was first observed. Since December 1995, the Department has been performing analysis and testing to better understand the observed benzene phenomenon.

Chemistry test program results have determined that TPB breaks down into intermediate products, producing benzene as each product decomposes. Certain waste components accelerate the decomposition reaction. Test results have indicated that benzene generation rates produced from decomposition reactions will cause benzene release rates to exceed the capacity of current plant hardware/systems. Not only does sodium TPB decompose, but potassium and cesium TPB can also decompose rapidly under certain conditions, threatening the ability to maintain the salt solution until prepared for vitrification processing at DWPF.

In January 1998, it was concluded that high benzene generation rates and precipitate solids instability would not support the ITP process as currently designed. As a result, ITP restart preparations were suspended pending the outcome of a system engineering evaluation of potential options for removing cesium from stored high level waste solutions. The Westinghouse Savannah River Company completed the alternatives evaluation in November 1998; however, DOE-SR concluded that additional R\&D was required to address uncertainties associated with the final "short list" alternatives before a preferred alternative could be selected. The additional R\&D was completed in 
October 1999, but there are still significant technical uncertainties associated with the cesium-removal technologies. In December 1999, DOE-SR recommended to the Assistant Secretary for Environmental Management (EM-1) that additional R\&D be performed to resolve the key technical uncertainties with the cesium-removal technologies until a preferred alternative with a high probability for success can be selected.

No further action with regard to resolution of $96-1$ issues is planned until a preferred alternative is selected. When selected, the potential alternative cesium-removal processes will be assessed to determine whether the 96-1 issues apply.

\section{Recommendation 95-2, Integrated Safety Management}

Recommendation 95-2 called for: 1) an institutionalization process for ensuring environment, safety, and health requirements are met; 2) graded safety management plans for the conduct of operations; 3 ) a prioritized list of facilities based on hazards and importance; 4) direction and guidance for the safety management process; and 5) measures to ensure availability of technical expertise to implement the streamlined process effectively. The Department's April 1996 implementation plan describes the Department's approach for implementing these recommendations.

Key accomplishments for 1999 are summarized below:

- In March 1999, the Secretary reiterated strong support for the ISMS framework and established September 2000 as the Department's expectation for completing verification of full implementation at all Department sites.

- In March 1999, the Secretary issued the Department's Plan to Address and Resolve Safety Issues Identified by Internal Independent Oversight, in response to issues raised by Board recommendation 98-1. The Safety Management Implementation Team Director, is responsible for implementing this plan. Significant progress was made on this plan in 1999.

- In April 1999, the Department issued Acquisition Regulation 970.5204-86 on Conditional Payment of Fee, Profit, or Incentives. This contract clause is directed at strengthening contractor accountability for safety and is being incorporated into all major contracts.

- In May 1999, the Secretarial Safety Council, established by the Secretary in March 1999, held its first meeting. The Secretarial Safety Council has established and is monitoring performance measures for ISM.

- In June 1999, the Department revised its Team Leader's Handbook for ISMS Verifications (DOE HDBK-3027-99) to reflect lessons learned on the conduct of verifications. This revision incorporated revised Criteria Review and 
Approach Documents (CRADs) used in verification evaluations of the feedback and improvement processes at sites.

- In July 1999 and September 1999, respectively, Defense Programs and Environmental Management completed reviews of their authorization agreements to identify good practices and lessons learned.

- In September 1999, the Safety Management Implementation Team Director issued for comment and interim use a draft Chapter IV to the Safety Management System Guide (DOE Guide 450.4-1A) on maintaining an approved ISMS.

- In October 1999, the Deputy Secretary established a requirement for each field and program office to report to him upon their completion of full implementation by September 2000, and provided implementation criteria for each program and field office to use in guiding their review and determination of full implementation.

- In October 1999, the Department revised and upgraded the first major revision to its Safety Management Functions, Responsibilities and Authorities Manual (DOE Manual 411.1-1A). Major changes addressed in this revision include: (1) changes in the Department's management structure, (2) changes in the Department's process for addressing and resolving safety issues identified by independent oversight, (3) changes and improvements recommended by a Safety Management Implementation Team (SMIT) review team, (4) changes related to technical qualification responsibilities, as recommended by the Department's Federal Technical Capability Panel, and (5) changes and upgrades as recommended by a variety of reviewers, including the Board staff, members of the SMIT, and complex-wide Departmental elements which have gained significant implementation experience. The Deputy Secretary subsequently established the expectations that these changes be implemented and reflected in lower-tier implementing documents by January 2000 for program offices and by March 2000 for field offices.

- In November 1999, a team of verification team leaders performed a review to identify good practices and recurrent weaknesses identified at sites and facilities which have completed their ISMS Verification reviews. The identified weaknesses and lessons learned were disseminated for use by other facilities and sites that have not yet completed implementation.

- The Department conducted three very successful workshops in 1999 to share good practices and lessons learned throughout the Department complex on three critical implementation topics: (1) ISM at the activity level - in May 1999 in Cincinnati, Ohio, (2) feedback and improvement - in July 1999 in Atlanta, Georgia, and (3) institutionalization - in November 1999 in Knoxville, Tennessee. 
- In December 1999, the Deputy Secretary issued performance measures for guiding and monitoring ISM implementation. These performance measures fall into three main categories: (1) Federal Personnel Accountability (revised Federal personnel performance standards); (2) Implementation Milestone Completion (Phase I verification, Phase II verification, authorization agreement approval, and oversight policy implementation, and (3) Effective ISM Implementation (total recordable case rate, occupational safety cost index, hypothetical radiation dose to the public, worker radiation dose, and reportable occurrences of releases to the environment).

- In December 1999, the Department revised its process and computer system tool for the identification and sharing of lessons learned. The changes, identified by field personnel, are intended to make the process and system more useful.

Throughout 1999, the Department developed and approved, as a result of Phase I verifications, more than 60 ISM system descriptions. Some of these descriptions cover site-wide activities, while others are facility-specific. Since the ISM program's inception, the Department has assembled multi-disciplined teams of experts and successfully completed ISM Phase II verifications for 61 facilities at 22 different locations.

The Department continues to make significant strides in implementing ISM. Key challenges to long-term success and institutionalization include the building of a stronger culture of accountability and completing the integration of various management systems. As reported in the 1996 Annual Report to Congress, the Department's 95-2 implementation plan has required more than one year to implement due to the magnitude of the fundamental changes involved in the Department's approach to safety management. The framework for safety management is now in place. All commitments identified in the Department's April 1996 implementation have been completed. Full implementation and institutionalization of ISM is scheduled to be accomplished Department-wide in September 2000.

\section{Recommendation 94-1, Improved Schedule for Remediation in the Defense Nuclear Facilities Complex}

Recommendation 94-1 concerns the need within the Department to address the hazards and risks involving the storage of nuclear materials within the defense nuclear facilities complex. The recommendation calls for an accelerated schedule for stabilizing and repackaging high risk, unstable special nuclear materials, spent fuel, unstable solid plutonium residues, and highly radioactive liquids that pose potential safety concerns for the public, workers, and the environment. The Department continues to face increased requirements, competing needs, and additional challenges in remediation and 
storage of materials from disassembled nuclear weapons and materials, materials production processes, and reclamation of former production sites, equipment, and stored products and wastes. Resolving the safety issues encompassed by this recommendation continues to be of the utmost importance.

The Department made significant progress in 1999 toward completing plan deliverables. Significant accomplishments for 1999 include the following:

- Completed 14 of the 55 milestones (25\%) contained in the implementation plan revision published in December 1998.

- Completed an additional one percent of the spent fuel movements to improved storage conditions at the Idaho National Engineering and Environmental Laboratory for a total to date of $84 \%$.

- Initiated operation of the prototype vertical calciner for plutonium solution stabilization at the Hanford Plutonium Finishing Plant (PFP).

- $\quad$ Resumed thermal stabilization of plutonium oxides at PFP. Stabilized over 150 items to date.

- $\quad$ Continued operation of the bagless transfer equipment for plutonium packaging at Savannah River. Using this equipment, $100 \%$ of all metal onsite has been packaged in a DOE-STD-3013-99 inner container.

- Completed tap-and-draining of all plutonium solution piping in Rocky Flats Environmental Technology Site Building 371. Tap-and-draining of remaining process piping in Building 771 is in progress and will lead to removal of all remaining solutions.

- Completed stabilization of all high risk salt residues, high risk ash, and ion exchange resins at Rocky Flats.

The Department's 94-1 implementation plan requires more than one year to complete due to the technical complexity and diversity of materials requiring stabilization at affected defense nuclear sites. A complete revision of the implementation plan was issued on December 28, 1998. A revision to reflect changes in the Hanford PFP baseline is expected to be approved and issued in early 2000 . Preparation of a new baseline for Savannah River Site 94-1 activities is scheduled to be complete in April 2000 at which time the Department expects to prepare another implementation plan revision for the Secretary's approval.

\section{E. Report on Implementation Plans Requiring More Than One Year}

When the Congress established the Board, they envisioned that the Department would typically be able to resolve Board recommendations within a relatively short period of time, such as within one year after the Department submits its implementation plan. To 
monitor the Department's performance in completing implementation plans, the Congress included a provision in the Board's enabling legislation which requires notification from the Department to Congress whenever the Department takes more than one year to complete an implementation plan in response to a Board recommendation. The enabling legislation also requires the reasons for requiring more than one year and the expected completion date.

The Department has required more than one year to complete a number of implementation plans for Board recommendations. This has occurred for a variety of reasons including the size and scope of issues being addressed and challenges in accomplishing complex-wide changes. The Department routinely makes the required Congressional notification in conjunction with the Department's Annual Report to Congress on Board activities (i.e., this report), which is also required by the Board's enabling legislation. In accordance with 42 U.S.C. $\S 2286 \mathrm{~d}(\mathrm{f})(1)$, the following active implementation plans are expected to require a total of more than one year to complete.

94-1, Improved Schedule for Remediation*

95-2, Safety Management*

96-i, In-Tank Precipitation System*

97-1, Safe Storage of Uranium-233*

97-2, Criticality Safety*

98-1, Resolution of Internal Oversight Findings

98-2, Safety Management at the Pantex Plant

* - Previously reported to require more than one year to implement.

The associated reasons and expected completion schedules for each implementation plan were provided with the previous discussion of Department activities for each Board recommendation.

\section{F. Categorization of Board Recommendations}

There are a number of ways to group and categorize Board recommendations. These groupings provide insights into the types of safety issues the Department is addressing and the schedules for issue resolution. Three different methods of categorizing recommendations are discussed below.

\section{Scope of Organizations Involved}

Recommendations vary in the scope of organizations involved. Three categories can be defined: 1) Department-wide, 2) multiple-sites/multiple-organizations, and 3) single- 
site/single-organization. In general, the more organizations that are involved, the more complex and time-consuming is the resolution. Department-wide recommendations are most likely to involve complex management and coordination efforts, and are also more likely to involve culture changes which require more time and attention to assimilate. Single-site recommendations are often of a more technical nature, while complex-wide recommendations often involve management issues. The following table shows the scope of organizations involved for open Board recommendations and also those closed over the past three years.

\section{DEPARTMENT-WIDE RECOMMENDATIONS}

\begin{tabular}{|c|c|}
\hline \multicolumn{1}{|c|}{ Open Recommendations } & \multicolumn{1}{c|}{ Closed Recommendations (1997-1999) } \\
\hline $\begin{array}{c}\text { 98-1, Resolution of DOE Internal Oversight } \\
\text { Findings }\end{array}$ & $94-5$, Rules, Orders, and Other Requirements \\
\hline $95-2$, Safety Management & $94-2$, Safety Standards for Low Level Waste \\
\hline $94-1$, Improved Schedule for Remediation & $93-3$, Improved Technical Capability \\
\hline
\end{tabular}

MULTIPLE-SITE/MULTIPLE-ORGANIZATION RECOMMENDATIONS

\begin{tabular}{|l|l|}
\hline \multicolumn{1}{|c|}{ Open Recommendations } & \multicolumn{1}{c|}{ Closed Recommendations (1997-1999) } \\
\hline $97-2$, Criticality Safety & $93-6$, Nuclear Weapons Expertise \\
\hline $97-1$, Safe Storage of Uranium-233 & $93-2$, Critical Experiments Capability \\
\hline & $\begin{array}{c}93-1, \text { Standards Utilization at Defense Nuclear } \\
\text { Programs }\end{array}$ \\
\hline
\end{tabular}

\section{SINGLE-SITE/SINGLE-ORGANIZATION RECOMMENDATIONS}

\begin{tabular}{|c|c|}
\hline Open Recommendations & Closed Recommendations (1997-1999) \\
\hline 99-1, Safe Storage of Pits at the Pantex Plant & $\begin{array}{l}\text { 95-1, Improved Safety of Cylinders Containing } \\
\text { Depleted Uranium (Oak Ridge) }\end{array}$ \\
\hline 98-2, Safety Management at the Pantex Plant & $\begin{array}{l}\text { 94-4, Deficiencies in Criticality Safety at Oak } \\
\text { Ridge Y-12 }\end{array}$ \\
\hline \multirow[t]{3}{*}{$\begin{array}{l}\text { 96-1, In-Tank Precipitation Facility (Savannah } \\
\text { River) }\end{array}$} & 94-3, Rocky Flats Seismic and Systems Safety \\
\hline & 93-5, Hanford Waste Tanks Characterization \\
\hline & $\begin{array}{l}\text { 92-4, Multi-Function Waste Tank Facility at } \\
\text { Hanford (proposed)* }\end{array}$ \\
\hline
\end{tabular}

* Closure Proposed on 12/16/98 


\section{Lead Implementing Organization}

Most Department implementation plans are managed from Department headquarters organizations.

\section{LEAD ORGANIZATION: ENVIRONMENTAL MANAGEMENT}

\begin{tabular}{|l||}
\hline Open Recommendations \\
\hline 97-1, Safe Storage of Uranium-233 \\
\hline 96-1, In-Tank Precipitation Facility (Savannah River Operations Office) \\
\hline 94-1, Improved Schedule for Remediation \\
\hline
\end{tabular}

LEAD ORGANIZATION: DEFENSE PROGRAMS

\begin{tabular}{|l||}
\hline Open Recommendations \\
\hline 99-1, Safe Storage of Pits at the Pantex Plant \\
\hline 98-2, Safety Management at the Pantex Plant \\
\hline 97-2, Criticality Safety \\
\hline
\end{tabular}

LEAD ORGANIZATION: OTHER HEADQUARTERS ORGANIZATIONS

\begin{tabular}{|l||}
\hline Open Recommendations \\
\hline 98-1, Resolution of Internal Oversight Findings (Office of the Deputy Secretary) \\
\hline 95-2, Safety Management (Office of the Deputy Secretary) \\
\hline
\end{tabular}

\section{Progress Toward Completion of Implementation Plans}

Implementation plans with long-term completion dates involve more uncertainty than those with shorter completion schedules. The projected deliverables and schedules are less certain the further out are the projected plan due dates. The long-term plans often involve research, development and application of new techniques. Due to the nature of these activities, the schedules are less certain and the basic direction of the plan may even need to be substantially changed based on the outcome of intermediate activities. For plans to be effective and useful, it must be understood that plan deliverables and milestones can not be known with certainty several years in advance and should not be held rigid in light of new information and new priorities. Flexibility is required in adjusting plan deliverables and milestones as the plan is being executed, particularly for plans that extend more than the one year that the Congress envisioned for typical implementation plan completion. 
IMPLEMENTATION PLANS COMPLETE

\begin{tabular}{||l||}
\hline Open Recommendations \\
\hline $97-1$, Safe Storage of Uranium-233 \\
\hline 95-2, Safety Management \\
\hline 92-4, Multi-Function Waste Tank Facility at Hanford \\
\hline
\end{tabular}

IMPLEMENTATION PLANS PROJECTED TO BE COMPLETE IN 2000

\begin{tabular}{|l|}
\hline Open Recommendations (Projected Completion) \\
\hline $98-1$, Resolution of Internal Oversight Findings (June, 2000) \\
\hline 97-2, Criticality Safety (2000) \\
\hline $96-1$, In-Tank Precipitation Facility at Savannah River (Pending outcome of alternatives review) \\
\hline
\end{tabular}

IMPLEMENTATION PLANS PROJECTED TO BE COMPLETE AFTER 2000

\begin{tabular}{|l|}
\hline Open Recommendations (Projected Completion) \\
\hline 98-2, Safety Management at the Pantex Plant (2001) \\
\hline 94-1, Improved Schedule for Remediation (2005) \\
\hline
\end{tabular}

\section{OTHER BOARD INTERFACE ACTIVITIES}

The Department shares with the Board the common goal of ensuring adequate protection at its defense nuclear facilities of the health and safety of the public. To accomplish this goal, the Department's policy has been to:

- Fully cooperate with the Board;

- Provide access to information necessary for the Board to accomplish its responsibilities;

- Thoroughly consider the recommendations and other safety information provided by the Board;

- Consistently meet commitments to the Board; and

- Conduct interactions with the Board in accordance with the highest professional standards.

The Office of the Departmental Representative to the Defense Nuclear Facilities Safety Board (Departmental Representative) manages the Department's overall interface with the Board and provides advice and direction for resolving identified safety issues. 


\section{Annual Report to Congress}

The Board and its staff have made a positive impact on Department safety across a wide variety of issues during 1999, particularly the development and accelerated implementation of ISM, and continued improvement in safety directives. The dialogue between the individual Board members and senior Department officials has been frank and open regarding improvements that were needed. As a result of interaction with the Board and its staff, the Department now has a more complete and effective set of safety requirements and expectations, and a more thorough understanding of how each of the previous safety requirements were addressed during the transition. The Board has also been instrumental in the development of Department guidance for incorporating new safety requirements into contracts and accomplishing contractor implementation.

\section{Coordination of Board Review of Department Safety Directives}

One of the Board's significant responsibilities is the review and evaluation of the Department's safety directives and standards that apply to the design, construction, operation, and decommissioning of Departmental defense nuclear facilities. In keeping with this function, the Board has reviewed the body of the Department's directives (including rules, policies, notices, orders, manuals, handbooks, guides, and standards) and identified those specific directives "of interest" to the Board. Whenever the Department develops changes to these identified directives or identifies new directives potentially "of interest" to the Board, the Board is provided an opportunity to review and comment on the changes prior to approval by Department management. The Office of the Departmental Representative coordinates this review process with the Board to ensure that the Board and it's staff are notified of each change and given an opportunity for review and comment prior to issuance. Appendix A provides both: 1) a listing of the orders identified as "of interest" to the Board, and 2) a listing of Departmental safety directives "of interest" to the Board that were changed in 1999.

\section{Briefings, Site Visits, and other Board Interactions}

The Department has continued to interact extensively and effectively with the Board and it's staff. Department personnel supported over 220 site briefings and site visits by the Board or it's staff in 1999. This has included provision of logistical and technical support and interface, as appropriate, to facilitate unrestricted access by the Board and its staff to the Department's facilities. Appendix B provides a summary of site visits supported by the Department during 1999. In addition, Department personnel conducted numerous teleconferences and video conferences to exchange information and resolve safety issues.

In 1999, the Department and the Board exchanged over 180 items of correspondence (not including transmittal of requested information and routine distribution of 
assessments and evaluations). A large portion of the written communications between the Board and the Department involves the Board's recommendations and the associated deliverables, schedules, and reporting requirements contained in the Department's implementation plans. In addition, the Department receives and responds to trip reports detailing visits by the Board or it's staff to the Department's facilities, as well as specific requests from the Board or it's staff for particular information or action by the Department. Appendix $\mathrm{C}$ provides a summary of key correspondence between the Department and the Board for 1999.

\section{Responses to Board Reporting Requirements}

The Board communicates with the Department through a variety of mechanisms including formal recommendations, formal reporting requirements, letters requesting action and information, letters providing suggestions, letters providing information such as staff issue reports and trip reports, Board and Board staff requests for information, public meetings, briefings and discussions, and site visits. The Board's choice of communication vehicle tends to indicate the level of the Board's concern, with the more formal vehicles used for clearly-defined safety issues that require prompt attention by Departmental managers. During 1999, the Board issued 11 sets of formal reporting requirements, pursuant to 42 U.S.C. $2286 \mathrm{~b}$ (d):

\begin{tabular}{|c|l|c|}
\hline Date & \multicolumn{1}{|c|}{ Topic of Reporting Requirements } & $\begin{array}{c}\text { Days for } \\
\text { Report }\end{array}$ \\
\hline $1 / 8 / 99$ & $\begin{array}{l}\text { Safety concerns regarding action to prepare for Year 2000 } \\
\text { (Y2K) compliance. }\end{array}$ & $30 / 60 / 90$ \\
\hline $1 / 28 / 99$ & $\begin{array}{l}\text { Effects of delaying construction of the Actinide Packaging and } \\
\text { Storage facility at Savannah River. }\end{array}$ & 60 \\
\hline $3 / 12 / 99$ & Need for a systems approach to pit storage programs. & 30 \\
\hline $5 / 11 / 99$ & $\begin{array}{l}\text { LANL safety management assessments and actions to } \\
\text { establish an Authorization Agreement at TA-18. }\end{array}$ & 30 \\
\hline $6 / 8 / 99$ & $\begin{array}{l}\text { Degradation of infrastructure supporting the high-efficiency } \\
\text { particulate air (HEPA) filter program. }\end{array}$ & 60 \\
\hline $6 / 23 / 99$ & Actions to complete the 93-3 implementation plan. & 30 \\
\hline $8 / 26 / 99$ & Implementation of the Operational Readiness Review Order. & 60 \\
\hline $11 / 2 / 99$ & Hazard reduction at Y-12. & 30 \\
\hline
\end{tabular}




\begin{tabular}{|c|l|c|}
\hline $11 / 9 / 99$ & $\begin{array}{l}\text { Execution of safety management principles and technical } \\
\text { safety issues at Y-12. }\end{array}$ & $30 / 120$ \\
\hline $12 / 1 / 99$ & $\begin{array}{l}\text { Decommissioning process for Hanford's 233-S plutonium } \\
\text { concentration facility. }\end{array}$ & 60 \\
\hline $12 / 6 / 99$ & Safety basis for handling composite weapons assemblies. \\
\hline
\end{tabular}

The Board's reporting requirements and the Department's responses are available on the Departmental Representative's web site at http://dr.tis.doe.gov.

\section{Board Public Meetings}

The Board holds public meetings periodically to review significant safety and management issues in a public forum. The Board provides advance public notice for these meetings pursuant to the provision of the "Government in the Sunshine Act" (5 U.S.C. $\S 552 \mathrm{~b}$ ). During 1999, the Department supported the following five public meetings conducted by the Board:

\begin{tabular}{|c|c|c|}
\hline Date & Topic of Public Meeting & Location \\
\hline $3 / 3 / 99$ & $\begin{array}{l}\text { Status of activities associated with the Department's } \\
\text { implementation plans for integrated safety management } \\
\text { (recommendation 95-2) and technical capability } \\
\text { (recommendation 93-3) }\end{array}$ & $\begin{array}{l}\text { Washington, } \\
\text { D.C. }\end{array}$ \\
\hline $5 / 25 / 99$ & $\begin{array}{l}\text { Status of integrating activities associated with the } \\
\text { Department's implementation plans for integrated safety } \\
\text { management (recommendation 95-2) and resolution of } \\
\text { oversight findings (recommendation 98-1) }\end{array}$ & $\begin{array}{l}\text { Washington, } \\
\text { D.C. }\end{array}$ \\
\hline 9/9/99 & $\begin{array}{l}\text { Status of activities associated with the Department's } \\
\text { implementation plan for stabilizing nuclear materials } \\
\text { (recommendation 94-1) }\end{array}$ & $\begin{array}{l}\text { Washington, } \\
\text { D.C. }\end{array}$ \\
\hline $9 / 29 / 99$ & $\begin{array}{l}\text { Status of progress of activities associated with the } \\
\text { Department's implementation plans for integrated safety } \\
\text { management (recommendation 95-2) and resolution of } \\
\text { oversight findings (recommendation 98-1) }\end{array}$ & $\begin{array}{l}\text { Washington, } \\
\text { D.C. }\end{array}$ \\
\hline $12 / 8 / 99$ & $\begin{array}{l}\text { Status of progress on the stabilization and clean-up activities } \\
\text { at the Hanford Site }\end{array}$ & $\begin{array}{l}\text { Richland, } \\
\text { Washington }\end{array}$ \\
\hline
\end{tabular}




\section{Secretary of Energy Quarterly Briefings with the Board Members}

The Secretary initiated scheduled quarterly briefings between the Board members and senior Department management in 1994. These sessions continued during 1999. The Department typically is represented in these quarterly sessions by the Secretary, Deputy Secretary, Under Secretary, and the Departmental Representative. This forum facilitates senior level information exchange on key safety and management issues, and on relative priorities and directions.

\section{Safety Issues Management System}

The Department established a Department-wide commitment management tool, the Safety Issues Management System, in August 1995. Through use of this tool, the Department has reduced the number of outstanding commitments related to Board recommendations from 694 in August 1995 to 80 in December 1999. The total number of overdue commitments related to Board recommendations has also declined significantly, from 245 in August 1995 to 26 in December 1999. In addition to commitments and actions related to Board recommendations, the Safety Issues Management System also manages commitments and actions related to other interactions between the Department and the Board, such as Board requests for action or information and Department commitments in letters to the Board. Since these "letter commitments" were first tracked in mid 1996, 271 letter commitments have been identified of which 241 have been completed.

The Office of the Departmental Representative conducts qualitative and technical reviews of the Department's implementation plans and other outgoing correspondence to the Board to identify and capture Department commitments. Commitment information identified from these documents is entered into the Safety Issues Management System database. Distribution of monthly summary reports on the status of commitment implementation or completion includes responsible Department managers, points of contact, and Secretarial Officers. These personnel can access detailed information, and use various view, sort, and report formats, via an on-line, internet-based user interface.

\section{Information Archive of Board-Related Documents}

The Departmental Representative maintains an information archive of all Department/Board correspondence, reports, plans, assessments, and transmittals. In 1996, the Departmental Representative began transferring the archived information onto a dedicated Internet web site, thus increasing accessibility within the Department complex and by the general public. During 1997 and 1998, the web site was substantially expanded and made more user-friendly. The objectives of the web site 
upgrade effort were to improve communications and coordination among Department interface personnel, to save time and money by eliminating paper distribution where practical, and to provide an effective web-based tool for interface personnel to research safety and management issues. At present, approximately 1,500 individual documents are provided on the web site. New documents are added promptly upon receipt.

The following types of documents are included in the information archive:

- Board recommendations,

- Department responses and implementation plans,

- Department letters to the Board,

- Board letters to the Department,

- Selected key letters concerning the status of recommendations,

- Policy statements from the Secretary and the Board,

- Annual Reports to Congress from the Secretary and the Board concerning Board-related matters,

- Operations/Area Office questions and answers about the Board,

- Resumes of the Board members,

- Department Manual for Interface with the Board, and

- Board staff issue reports provided to the Department by the Board. 


\section{Appendix A \\ Orders and Departmental Safety Directives of Interest to the Board}

This Appendix provides both: 1) a listing of the orders identified as "of interest" to the Board, and 2) a listing of Departmental safety directives "of interest" to the Board that were changed in 1999.

\begin{tabular}{|c|c|c|}
\hline Order & Title & Note \\
\hline 0151.1 & Comprehensive Emergency Management System & 3 \\
\hline O210.1 & Performance Indicators and Analysis of Operations Information & 3 \\
\hline $\mathrm{O} 225.1 \mathrm{~A}$ & Accident Investigations & 3 \\
\hline O231.1 & Environment, Safety, and Health Reporting & 3 \\
\hline $\mathrm{O} 232.1 \mathrm{~A}$ & Occurrence Reporting and Processing of Operations Information & 3 \\
\hline O251.1A & Directives System & 3 \\
\hline $\mathrm{O} 252.1$ & Technical Standards Program & 3 \\
\hline O360.1A & Federal Employee Training & 3 \\
\hline O414.1A & Quality Assurance & \\
\hline O420.1 & Facility Safety & 3 \\
\hline O425.1A & Startup and Restart of Nuclear Facilities & 3 \\
\hline 0430.1 & Life Cycle Asset Management & 3 \\
\hline O435.1 & Radioactive Waste Management & 4 \\
\hline O440.1A & Worker Protection Management for DOE Federal and Contractor Employees & 3 \\
\hline P441.1 & Radiological Protection for DOE Activities & 4 \\
\hline O451.1A & National Environmental Policy Act Compliance Program & 3 \\
\hline O452.1A & Nuclear Explosive and Weapon Surety Program & 3 \\
\hline O452.2A & Safety of Nuclear Explosive Operations & 3 \\
\hline O460.1A & Packaging and Transportation Safety & 3 \\
\hline 0460.2 & Departmental Materials Transportation and Packaging Management & 3 \\
\hline 0474.1 & Control and Accountability of Nuclear Materials & 1 \\
\hline $01360.2 B$ & Unclassified Computer Security Program & 1 \\
\hline 01540.2 & Hazardous Material Packaging for Transport - Administrative Procedures & 1 \\
\hline
\end{tabular}


1999 Annual Report to Congress

\begin{tabular}{|c|c|c|}
\hline Order & Title & Note \\
\hline $01540.3 \mathrm{~A}$ & Base Technology for Radioactive Material Transportation Packaging Systems & 1 \\
\hline O3790.1B & Federal Employee Occupational Safety and Health Program & 4 \\
\hline $04330.4 \mathrm{~B}$ & Maintenance Management Program & 1 \\
\hline 04700.1 & Project Management System & 1 \\
\hline $05000.3 \mathrm{~B}$ & Occurrence Reporting and Processing of Operations Information & 1 \\
\hline 05400.1 & General Environmental Protection Program & 1 \\
\hline $05400.2 \mathrm{~A}$ & Environmental Compliance Issue Coordination & 1 \\
\hline 05400.3 & Hazardous and Radioactive Mixed Waste Program & 4 \\
\hline 05400.4 & $\begin{array}{l}\text { Comprehensive Environmental Response, Compensation, and Liability Act } \\
\text { Requirements }\end{array}$ & 1 \\
\hline 05400.5 & Radiation Protection of the Public and the Environment & 1 \\
\hline O5440.1E & National Environmental Policy Act Compliance Program & 1 \\
\hline O5480.1B & Environment, Safety and Health Program for DOE Operations & 1 \\
\hline O5480.3 & $\begin{array}{l}\text { Safety Requirements for the Packaging and Transportation of Hazardous } \\
\text { Materials, Hazardous Substances, and Hazardous Wastes }\end{array}$ & 1 \\
\hline O5480.4 & Environment Protection, Safety, and Health Protection Standards & 1 \\
\hline 05480.5 & Safety of Nuclear Facilities & 1 \\
\hline 05480.6 & Safety of Department of Energy-Owned Nuclear Reactors & 1 \\
\hline O5480.7A & Fire Protection & 1 \\
\hline $05480.8 \mathrm{~A}$ & Contractor Occupational Medical Program & 1 \\
\hline $05480.9 \mathrm{~A}$ & Construction Safety and Health Program & 1 \\
\hline 05480.10 & Contractor Industrial Hygiene Program & 1 \\
\hline 05480.11 & Radiation Protection for Occupational Workers & 1 \\
\hline 05480.15 & Department of Energy Laboratory Accreditation Program for Personnel Dosimetry & 1 \\
\hline O5480.17 & Site Safety Representatives & 1 \\
\hline 05480.18 & Environment Safety and Health Program for DOE Operations & \\
\hline $\mathrm{O} 5480.18 \mathrm{~B}$ & Nuclear Facility Training Accreditation Program & 1 \\
\hline 05480.19 & Conduct of Operations Requirements for DOE Facilities & 1 \\
\hline
\end{tabular}




\begin{tabular}{|c|c|c|}
\hline Order & Title & Note \\
\hline $05480.20 \mathrm{~A}$ & $\begin{array}{l}\text { Personnel Selection, Qualification, Training and Staffing Requirements at DOE } \\
\text { Reactor and Non-Reactor Nuclear Facilities }\end{array}$ & 1 \\
\hline O5480.21 & Unreviewed Safety Questions & 1 \\
\hline 05480.22 & Technical Safety Requirements & 1 \\
\hline 05480.23 & Nuclear Safety Analysis Reports & 1 \\
\hline 05480.24 & Nuclear Criticality Safety & 1 \\
\hline 05480.25 & Safety of Accelerator Facilities & 1 \\
\hline 05480.26 & Trending and Analysis of Operations Information Using Performance Indicators & 1 \\
\hline 05480.28 & Natural Phenomena Hazards Mitigation & 1 \\
\hline O5480.29 & Employee Concerns Management System & 1 \\
\hline 05480.30 & Nuclear Reactor Safety Design Criteria & 1 \\
\hline O5480.31 & Startup and Restart of Nuclear Facilities & 1 \\
\hline O5481.1B & Safety Analysis and Review System & 1 \\
\hline O5482.1B & Environment, Safety, and Health Appraisal Program & 1 \\
\hline O5483.1A & $\begin{array}{l}\text { Occupational Safety and Health Program for DOE Contractor Employees at } \\
\text { Government-Owned Contractor-Operated Facilities }\end{array}$ & 1. \\
\hline O5484.1B & $\begin{array}{l}\text { Environmental Protection, Safety and Health Protection Information Reporting } \\
\text { Requirements }\end{array}$ & 1 \\
\hline O5500.1B & Emergency Management System & 1 \\
\hline O5500.2B & Emergency Categories, Classes, and Notification and Reporting Requirements & 1 \\
\hline O5500.3A & Planning and Preparedness for Operational Emergencies & 1 \\
\hline O5500.4A & Public Affairs Policy and Planning Requirements for Emergencies & 1 \\
\hline O5500.7B & Emergency Operating Records Protection Program & 1 \\
\hline 05500.10 & Emergency Readiness Assurance Program & 1 \\
\hline O5530.1A & Accident Response Group & 2 \\
\hline 05530.2 & Nuclear Emergency Search Team & 2 \\
\hline O5530.3 & Radiological Assistance Program & 2 \\
\hline
\end{tabular}




\begin{tabular}{|c|c|c|}
\hline Order & Title & Note \\
\hline 05530.4 & Aerial Measuring System & 2 \\
\hline 05600.1 & $\begin{array}{l}\text { Management of the Department of Energy Weapon Program and Weapon } \\
\text { Complex }\end{array}$ & 2 \\
\hline O5610.10 & Nuclear Explosive and Weapon Safety Program & 2 \\
\hline 05610.11 & Nuclear Explosive Safety & 2 \\
\hline 05610.12 & $\begin{array}{l}\text { Packaging and Offsite Transportation of Nuclear Components, and Special } \\
\text { Assemblies Associated with the Nuclear Explosive and Weapon Safety Program }\end{array}$ & 2 \\
\hline O5632.1C & Protection and Control of Safeguards and Security Interests & 1 \\
\hline 05632.11 & Physical Protection of Unclassified Irradiated Reactor Fuel in Transit & 4 \\
\hline $05700.6 \mathrm{C}$ & Quality Assurance & 1 \\
\hline O6430.1A & General Design Criteria & 1 \\
\hline 10CFR 820 & Procedural Rules for DOE Nuclear Activities & 3 \\
\hline $\begin{array}{l}10 \text { CFR830.: } \\
10\end{array}$ & Safety Analysis Reports & 3. \\
\hline $\begin{array}{l}10 \mathrm{CFR} 830.1 \\
12\end{array}$ & Unreviewed Safety Requirements & 3 \\
\hline $\begin{array}{l}10 \text { CFR. } \\
830.120\end{array}$ & Quality Assurance Requirements & 3 \\
\hline $\begin{array}{l}10 \text { CFR } \\
830.310\end{array}$ & Conduct of Operations & 3 \\
\hline $\begin{array}{l}10 \mathrm{CFR} \\
830.320\end{array}$ & Technical Safety Requirements & 3 \\
\hline $\begin{array}{l}10 \mathrm{CFR} \\
330.330\end{array}$ & Training and Qualification & 3 \\
\hline $\begin{array}{l}10 \mathrm{CFR} \\
830.340\end{array}$ & Maintenance Management & 3 \\
\hline 10 CFR 834 & Radiation Protection of the Public and the Environment & 3 \\
\hline 10 CFR 835 & Occupational Radiation Protection & 3 \\
\hline
\end{tabular}


Notes:

(1) On Board's original list of 51 Orders of Interest; some of these have been canceled but remain in effect in certain contracts.

(2) Added to Board's list of Orders of Interest with expansion of Board's jurisdiction to include weapons assembly, disassembly, and testing safety.

(3) Added to Board's list due to conversion to three-digit orders and nuclear safety rules.

(4) Other additions based on ongoing Board staff review and evaluation. 
DOE Safety Directives Coordinated with the Board Staff

And Issued in 1999

\begin{tabular}{|c|c|c|c|c|}
\hline Directive & Title & Date & $\begin{array}{c}\text { New/ } \\
\text { Revised }\end{array}$ & Comment \\
\hline 0435.1 & Radioactive Waste Management & $7 / 9 / 99$ & revised & Replaced O 5820.2A \\
\hline 0252.1 & Technical Standards Program & $11 / 19 / 99$ & revised & Replaced O 1300.2A \\
\hline $\mathrm{O} 474.1$ & $\begin{array}{l}\text { Control and Accountability of Nuclear } \\
\text { Materials }\end{array}$ & $8 / 11 / 99$ & revised & Replaced O 5633.3B \\
\hline $\mathrm{O} 414.1 \mathrm{~A}$ & Quality Assurance & $9 / 29 / 99$ & revised & Replaced O 414.1 \\
\hline $\mathrm{O} 360.1 \mathrm{~A}$ & Federal Employee Training & $9 / 21 / 99$ & revised & Replaced O 360.1 \\
\hline M 140.1-1A & $\begin{array}{l}\text { Interface with the Board Nuclear } \\
\text { Facilities }\end{array}$ & $1 / 26 / 99$ & revised & Replaced M 140.1-1 \\
\hline M 452.4-1 & $\begin{array}{l}\text { Protection of Use Control } \\
\text { Vulnerabilities and Designs }\end{array}$ & $7 / 1 / 99$ & new & \\
\hline$M 435.1-1$ & $\begin{array}{l}\text { Radioactive Waste Management } \\
\text { Manual }\end{array}$ & $7 / 9 / 99$ & new & \\
\hline M 474.1-1 & $\begin{array}{l}\text { Manual for Control and Accountability } \\
\text { of Nuclear Materials }\end{array}$ & $8 / 11 / 99$ & new & \\
\hline $\mathrm{M} 411.1-1 \mathrm{~A}$ & $\begin{array}{l}\text { Safety Management Functions, } \\
\text { Responsibilities and Authorities } \\
\text { Manual }\end{array}$ & $10 / 18 / 99$ & revised & Replaced M 411.1-1 \\
\hline M 360.1A & Federal Employee Training Manual & $10 / 18 / 99$ & new & \\
\hline G 252.1-1 & Technical Standards Program Guide & $11 / 19 / 99$ & new & \\
\hline G 441.1-1 & $\begin{array}{l}\text { Management and Administration of } \\
\text { Radiation Protection Programs Guide }\end{array}$ & $3 / 17 / 99$ & new & \\
\hline G 441.1-2 & Occupational ALARA Program Guide & $3 / 17 / 99$ & new & \\
\hline G 441.1-3 & Internal Dosimetry Program Guide & $3 / 17 / 99$ & new & . \\
\hline G 441.1-4 & External Dosimetry Program Guide & $3 / 17 / 99$ & new & \\
\hline G 441.1-5 & Radiation-Generating Devices Guide & $4 / 15 / 99$ & new & \\
\hline
\end{tabular}




\begin{tabular}{|c|c|c|c|c|}
\hline Directive & Title & Date & $\begin{array}{l}\text { New/ } \\
\text { Revised }\end{array}$ & Comment \\
\hline G $441.1-6$ & $\begin{array}{l}\text { Evaluation and Control of Radiation } \\
\text { Dose to the Embryo/Fetus Guide }\end{array}$ & $4 / 29 / 99$ & new & \\
\hline G 441.1-7 & $\begin{array}{l}\text { Portable Monitoring Instrument } \\
\text { Calibration Guide }\end{array}$ & $6 / 17 / 99$ & new & \\
\hline G 441.1-8 & Air Monitoring Guide & $3 / 17 / 99$ & new & \\
\hline G 441.1-9 & Radioactive Contamination Control & $6 / 17 / 99$ & new & \\
\hline $\mathrm{G} 441.1-10$ & $\begin{array}{l}\text { Posting and Labeling for Radiological } \\
\text { Control }\end{array}$ & $5 / 24 / 99$ & new & \\
\hline G 441.1-11 & $\begin{array}{l}\text { Occupational Radiation Protection } \\
\text { Record-Keeping and Reporting Guide }\end{array}$ & $5 / 20 / 99$ & new & \\
\hline G 441.1-12 & Radiation Safety Training Guide & $3 / 17 / 99$ & new & \\
\hline $\mathrm{G} 441.1-13$ & $\begin{array}{l}\text { Sealed Radioactive Source } \\
\text { Accountability and Control Guide }\end{array}$ & $4 / 15 / 99$ & new & \\
\hline G 414.1-2 & $\begin{array}{l}\text { Quality Assurance Management } \\
\text { System }\end{array}$ & $6 / 17 / 99$ & new & . \\
\hline G 421.1-1 & $\begin{array}{l}\text { DOE Good Practices Guide Criticality } \\
\text { Safety Good Practices Program Guide }\end{array}$ & $8 / 25 / 99$ & new & \\
\hline G 430.1-2 & $\begin{array}{l}\text { Implementation Guide for Surveillance } \\
\text { and Maintenance During Facility } \\
\text { Transition and Disposition }\end{array}$ & $9 / 29 / 99$ & new & \\
\hline G $430.1-3$ & Deactivation Implementation Guide & $9 / 29 / 99$ & new & \\
\hline G $430.1-4$ & $\begin{array}{l}\text { Decommissioning Implementation } \\
\text { Guide }\end{array}$ & $9 / 2 / 99$ & new & \\
\hline G 435.1-1 & $\begin{array}{l}\text { Implementation Guide for use with } \\
\text { DOE M 435.1-1 }\end{array}$ & $7 / 9 / 99$ & new & \\
\hline $\mathrm{G} 450.4-1 \mathrm{~A}$ & $\begin{array}{l}\text { Integrated Safety Management System } \\
\text { Guide }\end{array}$ & $5 / 27 / 99$ & revised & Replaced G 450.4-1 \\
\hline $\begin{array}{l}\text { STD-1066- } \\
99\end{array}$ & Fire Protection Design Criteria & $9 / 99$ & new & \\
\hline $\begin{array}{l}\text { STD-1098- } \\
99\end{array}$ & Radiological Control & $9 / 99$ & new & \\
\hline
\end{tabular}




\begin{tabular}{|c|c|c|c|c|}
\hline Directive & Title & Date & $\begin{array}{c}\text { New/ } \\
\text { Revised }\end{array}$ & Comment \\
\hline $\begin{array}{l}\text { STD-1121- } \\
98\end{array}$ & Internal Dosimetry Technical Standard & $12 / 99$ & new & \\
\hline $\begin{array}{l}\text { STD-1134- } \\
99\end{array}$ & $\begin{array}{l}\text { Review Guide for Criticality Safety } \\
\text { Evaluations }\end{array}$ & $9 / 99$ & new & \\
\hline $\begin{array}{l}\text { STD-1135- } \\
99\end{array}$ & $\begin{array}{l}\text { Guidance for Nuclear Criticality } \\
\text { Safety Engineer Training and } \\
\text { Qualification }\end{array}$ & $9 / 99$ & new & \\
\hline $\begin{array}{l}\text { STD-3013- } \\
99\end{array}$ & $\begin{array}{l}\text { Stabilization, Packaging, and Storage } \\
\text { of Plutonium-Bearing Materials }\end{array}$ & $12 / 99$ & new & \\
\hline $\begin{array}{l}\text { HDBK- } \\
1117-99\end{array}$ & $\begin{array}{l}\text { Guide to Good Practices for } \\
\text { Maintenance Supervisor Selection and } \\
\text { Development }\end{array}$ & $12 / 99$ & new & \\
\hline $\begin{array}{l}\text { HDBK- } \\
1118-99\end{array}$ & $\begin{array}{l}\text { Guide to Good Practices for } \\
\text { Continuing Training }\end{array}$ & $12 / 99$ & new & \\
\hline $\begin{array}{l}\text { HDBK- } \\
1122-99\end{array}$ & $\begin{array}{l}\text { Radiological Control Technician } \\
\text { (RCT) Training }\end{array}$ & $7 / 99$ & new & \\
\hline $\begin{array}{l}\text { HDBK- } \\
1132-99\end{array}$ & Design Considerations & $4 / 99$ & new & \\
\hline $\begin{array}{l}\text { HDBK- } \\
3027-99\end{array}$ & $\begin{array}{l}\text { Integrated Safety Management } \\
\text { Systems Verification Team Leader's } \\
\text { Handbook }\end{array}$ & $5 / 99$ & new & \\
\hline
\end{tabular}




\section{Appendix B \\ Site Visits Supported by the Department in 1999}

\section{Argonne National Laboratory}

\section{Albuquerque}

- On January 19-21, 1999, the Board's staff visited Albuquerque to attend the Plutonium Storage Standard Working Group meeting.

- On February 8-11, 1999, the Board's staff visited Albuquerque to discuss research and development related to recommendation 94-1.

- On February 19, 1999, the Board's staff visited Albuquerque to discuss the surveillance program.

- On March 8-12, 1999, the Board's staff visited Albuquerque to discuss research and development safety in support of the Board's visit.

- On March 8-12, 1999, the Board's staff visited Albuquerque to survey weapons development and technology.

- On March 9, 1999, the Board visited Albuquerque for a site visit.

- On March 29 - April 1, 1999, the Board's staff visited Albuquerque to review Y2K compliance, conduct a technical visit at TA-5, review fire hazards, and follow up on integrated safety management at the Sandia National Laboratory.

- On May 19-21, 1999, the Board's staff visited Albuquerque to review weapons high explosive aging effects with the Los Alamos National Laboratory, Lawrence Livermore National Laboratory, and the Sandia National Laboratory.

- On May 24-28, 1999, the Board's staff visited Albuquerque to evaluate the Department's directives and plans for Nuclear Explosive Operations change controls.

- On June 3-4, 1999, the Board's staff visited Albuquerque to attend the Weapons Program Division standing management team meeting.

- On June 22-24, 1999, the Board's staff visited Albuquerque to attend the recommendation 97-1 Technical Team meeting.

- On November 15-18, 1999, the Board's staff visited Albuquerque to attend the Integrated Nuclear Materials Management meeting.

\section{$\underline{\text { Amarillo }}$}




\section{Hanford}

- On January 11-15, 1999, the Board's staff visited Hanford to observe the startup of thermal stabilization activities.

- On February 1-4, 1999, the Board's staff visited Hanford to review the path forward for closure of the Board's recommendation 93-5, and Tank C-106 Sluicing.

- On February 16-19, 1999, the Board's staff visited Hanford to review the Spent Nuclear Fuel Project's current design and safety analysis activities, tour the Canister Storage Building and Cold Vacuum Drying Facility, and review PFP HEPA filters.

- On February 22-25, 1999, the Board's staff visited Hanford to review closure to the Board's recommendation 93-5, vadose zone integration project, and K-Basins sludge treatment options analysis.

- On March 22-25, 1999, the Board's staff visited Hanford to discuss integrated planning at the Plutonium Finishing Plant.

- On March 22-26, 1999, the Board's staff visited Hanford to review the Spent Nuclear Fuel Program.

- On April 12-16, 1999, the Board's staff visited Hanford to attend the tank advisory panel meeting regarding surface level growth in 101SY, and receive a briefing on Hanford ISMS Verification Strategy.

- On April 26, 1999, the Richland Operations Office and contractors briefed the Board staff in Washington, DC on Project Integration.

- On May 3-7, 1999, the Board's staff visited Hanford for a design review of the Spent Nuclear Fuel Cold Vacuum Drying Facility, and Cask Loadout System Cask Drop.

- On May 25-27, 1999, the Board's staff visited Hanford to review the Plutonium Finishing Plant Integrated Project Management Plan.

- On June 1-4, 1999, the Board's staff visited Hanford to evaluate the 94-1 implementation plan progress at the Plutonium Finishing Plant and the deactivation program review.

- On June 10-11, 1999, the Board's staff visited Hanford to attend the Cask Drop review meeting, and tour $\mathrm{K}$ West Basin.

- On June 14-18, 1999, the Board's staff visited Hanford to review deactivation and decommissioning work planning and prioritization, and review recommendation 93-5 status.On June 28-July 2, 1999, the Board's staff visited Hanford to review the 101-SY Surface Level Rise Remediation Project. 
- On July 26-27, 1999, the Board's staff visited Hanford to attend a Worker Safety Meeting, and tour PFP, CSB, and K West Basin.

- On July 26-28, 1999, the Board and its staff visited Hanford to review Spent Nuclear Fuel Project status, PFP, Office of River Protection, and ISM.

- On July 26-29, 1999, the Board's staff visited Hanford to attend the Worker Safety Meeting.

- On August 4, 1999, the Board's staff visited Hanford for a briefing on K Basin Sludge.

- On August 15-19, 1999, the Board's staff visited Hanford to receive a briefing on the Spent Nuclear Fuel Project status.

- On August 16-20, 1999, the Board's staff visited Hanford to observe the Low-Level Waste Federal Review Group's review of the Performance Assessment and Composite Analysis, discuss the transuranic waste program, and tour WRAP and the low-level burial grounds.

- On September 13-16, 1999, the Board's staff visited Hanford to observe the Tank Advisory Panel's discussion on 101-SY Back Dilution.

- On October 18-22, 1999, the Board's staff visited Hanford to review recommendation 94-1 activities at the Plutonium Finishing Plant, and the Tank 101-SY transfer safety and authorization basis information.

- On November 15-19, 1999, the Board's staff visited Hanford to observe verification of ISMS for the Spent Nuclear Fuel Project, and review Spent Nuclear Fuel safety analysis and cask drop issues, as well as Tank Farms Final Safety Analysis Report status, and Office of River Protection Project Integration Office status.

- On December 8, 1999, the Board held a public meeting at the Red Lion Hotel, Richland, WA, to review the Department's progress on the stabilization and clean-up activities at the Hanford Site.

- On December 8-10, 1999, the Board and its staff visited Hanford for a site visit.

\section{Idaho National Engineering and Environmental Laboratory}

- On February 10-11, 1999, the Board's staff visited the Idaho National Engineering and Environmental Laboratory to participate in the Uranium-233 Technical Team meeting. 
- On February 22-25, 1999, the Board's staff visited the Idaho National Engineering and Environmental Laboratory for a tour and meet the Idaho State and Environmental Protection Agency Representative.

- On February 22-25, 1999, the Board's staff visited the Idaho National Engineering and Environmental Laboratory to observe the prioritization hazard and mitigation review.

- On March 3, 1999, a Board member discussed with the Department concerning the Integrated Safety Management system at the Idaho National Engineering and Environmental Laboratory.

- On April 5-9 the Board's staff visited Idaho National Engineering and Environmental Laboratory to observe the integrated safety management system verification review.

- On April 12-16, 1999, the Board's staff visited the Idaho National Engineering and Environmental Laboratory to observe the integrated safety management verification review.

- On April 20, 1999, the Board will be briefed by the Department on the results of the Idaho National Engineering and Environmental Laboratory Phase I Integrated Safety Management System Verification.

- On April 27-30, 1999, the Board's staff visited the Idaho National Engineering and Environmental Laboratory for a prioritization, hazard, and mitigation review.

- On May 24-28, 1999, the Board's staff visited the Idaho National Engineering and Environmental Laboratory to observe conduct of operations at the Idaho Nuclear Technology and Engineering Center.

- On July 28, 1999, a Board member traveled to the Idaho National Engineering and Environmental Laboratory for a site visit.

- On July 26-30, 1999, the Board's staff visited the Idaho National Engineering and Environmental Laboratory to observe spent nuclear fuel handling and storage and support a site visit.

- On September 13-17, 1999, the Board's staff visited the Idaho National Engineering and Environmental Laboratory to observe ISMS Phase II Verification.

- On October 18-22, 1999, the Board's staff visited the Idaho National Engineering and Environmental Laboratory to observe work planning and implementation.

Kansas City Plant 
- On March 22-26, 1999, the Board's staff visited the Kansas City Plant for the Enhanced Surveillance Program conference and to tour the strong link testing laboratory.

\section{Lawrence Livermore National Laboratory}

- On January 11-13, 1999, the Board's staff visited Lawrence Livermore National Laboratory to review work smart standards.

- On January 11-15, 1999, the Board's staff visited Lawrence Livermore National Laboratory to review Plutonium Facility resumption of operations activities, work smart standards, and observe Plutonium Facility Integrated Management System Phase I Pre-Verification Review.

- On January 25-29, 1999, the Board's staff visited the Lawrence Livermore National Laboratory to observe the Independent Work Smart Standard Confirmation Review.

- On March 8-11, 1999, the Board's staff visited Lawrence Livermore National Laboratory to discuss Building 332 restart.

- On March 22-26, 1999, the Board's staff visited Lawrence Livermore National Laboratory to observe the work smart standards confirmation team.

- On April 14, 1999, the Lawrence Livermore National Laboratory briefed the Board on the status of Building 332.

- On April 22, 1999, the Board was briefed by the Department on plans for the Integrated Safety Management Verification assessment at Lawrence Livermore National Laboratory.

- On June 7-11, 1999, the Board's staff visited the Lawrence Livermore National Laboratory to review Superblock Integrated Safety Management System Phase I verification. On June 21-25, 1999, the Board's staff visited the Lawrence Livermore National Laboratory to observe the Superblock Integrated Safety Management System verification.

- On June 28-July 2, 1999, the Board's staff visited the Lawrence Livermore National Laboratory to observe the Superblock Integrated Safety Management System veification.

- On July 12-16, 1999, the Board's staff visited the Lawrence Livermore National Laboratory to observe the Superblock Integrated Safety Management System verification.

- $\quad$ On August 23-25, 1999, the Board's staff visited the Lawrence Livermore National Laboratory for the Integrated Safety Management System verification pre-brief. 
- On September 13-17, 1999, the Board's staff visited the Lawrence Livermore National Laboratory to observe ISMS Phase I and II verification.

- On September 20-24, 1999, the Board's staff visited the Lawrence Livermore National Laboratory to observe Superblock ISMS Phase I and II verification.

- On November 1-5, 1999, the Board's staff visited the Lawrence Livermore National Laboratory to observe the ISMS Phase I verification.

- On November 30-December 2, 1999, the Board's staff visited the Lawrence Livermore National Laboratory to review the implementation status of recommendation 94-1.

\section{Lawrence Berkeley}

\section{Los Alamos National Laboratory}

- On February 16-19, 1999, the Board's staff visited the Los Alamos National Laboratory to review resumption of operations at TA-18.

- On March 9-12, 1999, the Board's staff visited the Los Alamos National Laboratory to attend the criticality Safety Review Conference.

- On March 15-19, 1999, the Board's staff visited the Los Alamos National Laboratory to review implementation of safe work practices.

- On April 5-9, 1999, the Board's staff visited the Los Alamos National Laboratory to review the implementation of safe work practices.

- On April 27-29, 1999, the Board's staff visited the Los Alamos National Laboratory to review dynamic experimentation.

- On June 14-18, 1999, the Board's staff visited the Los Alamos National Laboratory to review fire protection, electrical, lightning, and $\mathrm{Y} 2 \mathrm{~K}$ issues.

- On June 22-25, 1999, the Board's staff visited the Los Alamos National Laboratory to support a site visit.

- On July 19-22, 1999, the Board's staff visited the Los Alamos National Laboratory to review dynamic experiments and TA-55 safety issues.

- On September 7-10, 1999, the Board's staff visited the Los Alamos National Laboratory to observe the dynamic experiment and review project management issues.

- On October 5-8, 1999, the Board's staff visited the Los Alamos National Laboratory to review dynamic experiment and receive overview tours. 
- $\quad$ On October 20-22, 1999, the Board and its staff visited the Los Alamos National Laboratory for a site visit.

- On October 25-29, 1999, the Board's staff visited the Los Alamos National Laboratory to discuss the Integrated Safety Management System verification and the quality of authorization basis.

- On November 3-5, 1999, the Board's staff visited the Los Alamos National Laboratory to review the implementation of recommendation 94-1 and overview of deactivation and decommissioning.

- On November 29-December 4, 1999, the Board's staff visited the Los Alamos National Laboratory to observe the advanced criticality safety class.

- On December 6-9, 1999, the Board's staff visited the Los Alamos National Laboratory to review the quality of Authorization Bases.

\section{Mound Site}

- On January 19-21, 1999, the Board's staff visited the Mound Site to attend an Environmental Management meeting regarding metal tritides.

- On March 8-11, 1999, the Board's staff visited the Mound Site to review deactivation and decommissioning of tritium systems.

\section{Nevada Test Site}

- $\quad$ On January 25-29, 1999, the Board's staff visited Nevada Operations Office to observe the Department of Energy's operating data analysis forum.

- On March 30-April 1, 1999, the Board's staff visited the Nevada Operations Office to discuss pit corrosion.

- On April 13-15, 1999, the Board's staff visited the Nevada Test Site to observe safety management of operations.

- $\quad$ On June 21-25, 1999, the Board's staff visited the Nevada Operations Office for the Department of Energy's Facility Representative's Program Conference.

- $\quad$ On June 29-July 2, 1999, the Board's staff visited the Nevada Operations Office to attend the safety evaluation panel review for subcritical experiments (OBOE).

- On August 3-5, 1999, the Board's staff visited the Nevada Test Site to review the JASPER project. 
- On August 23-25, 1999, the Board's staff visited the Nevada Test Site to observe the Disposition Focus Group meeting.

- On September 27-30, 1999, the Board's staff visited the Nevada Test Site to review the JASPER facility.

- On November 29-December 2, 1999, the Board's staff visited the Nevada Test Site to observe the disposition of damaged nuclear weapons exercise.

\section{Oakland Site}

- $\quad$ On April 12-16, 1999, the Board's staff visited the Oakland Operations Office to observe a decommissioning committee meeting.

\section{Oak Ridge Site}

- On February 9, 1999, the Department briefed the Board on the results of the EH review of the Oak Ridge Y-12 Plant integrated safety management system.

- On February 16-18, 1999, the Board's staff visited Oak Ridge to review preparations for Enriched Uranium Operations Phase B startup.

- On February 17-19, 1999, the Board's staff visited Oak Ridge to review safety management of Y-12 disassembly and assembly activities for W56 components.

- On March 8-10, 1999, the Board's staff yisited the Oak Ridge Y-12 Plant to review criticality safety.

- On March 16, 1999, the Department briefed the Board on the plans for the Uranium-233 Inspection Program at the Oak Ridge Building 3019.

- On March 17-19, the Board's staff visited Oak Ridge to review the Highly Enriched Uranium Storage Facility.

- $\quad$ On March 22-23, 1999, the Board's staff visited Oak Ridge to discuss uranium-233 disposition options.

- On March 22-26, 1999, the Board's staff visited Oalk Ridge to observe a preliminary meeting concerning Phase I of the Oak Ridge National Laboratory Integrated Safety Management System Verification.

- $\quad$ On April 19-23, 1999, the Board's staff visited Oak Ridge to observe the Integrated Safety Management Phase I Verification. 
- On May 4-6, 1999, the Board's staff visited Oak Ridge to review emergency preparedness at the Chemical Hazard Analysis.

- On May 17-19, 1999, the Board's staff visited Oak Ridge to review the Phase I Uranium-233 inspections preparation.

- On May 19-21, 1999, the Board's staff visited Oak Ridge to review the restart preparations for Y12 Enriched Uranium Operations Phase B.

- On June 2-4, 1999, the Board's staff visited Oak Ridge to review highly enriched uranium materials facility and project management issues.

- On June 28-July 1, 1999, the Board's staff visited Oak Ridge to observe the Facility Safety Basis Reviews.

- On June 29-July 1, 1999, the Board's staff visited Oak Ridge to observe the prioritization hazard and mitigation review.

- On July 26-30, 1999, the Board's staff visited Oak Ridge to review the Uranium-233 Inspection Readiness Preparations.

- On July $27-30,1999$, the Board's staff visited Oak Ridge to discuss the reduction process in Building 9212 to resume operations.

- On August 9-11, 1999, the Board's staff visited Oak Ridge to review the systems engineering aspects of highly enriched uranium facility project.

- On August 11, 1999, the Department and the Oak Ridge Operations Office briefed the Board on the Emergency Preparedness Shortcomings Plan.

- On August 17-18, 1999, the Board's staff visited Oak Ridge to observe the dismantlement of W56.

- On August 30, 1999, the Board's staff visited Oak Ridge for a site visit.

- On August 31-September 1, 1999, the Board's staff visited Oak Ridge to attend the 971 Technical Team meeting.

- On September 8-9, 1999, the Board's staff visited Oak Ridge to review transuranic waste management plans.

- On September 9-10, 1999, the Board's staff visited Oak Ridge to observe risk reduction activities at Building 9206.

- On September 14-16, 1999, the Board's staff visited Oak Ridge to review the ventilation systems in Building 3019. 
- On September 16-17, 1999, the Board's staff visited Oak Ridge to observe building 9206 deactivation.

- On October 6-8, 1999, the Board's staff visited Oak Ridge to review transuranic waste management.

- On October 18, 1999, the Board's staff visited Oak Ridge to observe the W56 and W71 Safety Basis Reviews.

- On November 1-5, 1999, the Board's staff visited Oak Ridge to review readiness assessment of the enriched uranium operations reduction furnace at the Y-12 Plant.

- On November 9-10, 1999, the Board's staff visited Oak Ridge to review instrumentation and control activities and the $\mathrm{Y} 2 \mathrm{~K}$ contingency planning.

- On November 30-December 2, 1999, the Board's staff visited Oak Ridge to observe the Uranium-233 peer review.

- On December 8-9, 1999, the Board's staff visited Oak Ridge to observe 50\% design review for transuranic waste facility and $\mathrm{Y}-12$ project management issues

- On December 15-16, 1999, the Board's staff visited Oak Ridge to review hydrogen fluoride instrumentation and control, enriched uranium operations, and $\mathrm{Y} 2 \mathrm{~K}$ readiness.

\section{Pacific Northwest Laboratory}

\section{Pantex Plant}

- On January 11-14, 1999, the Board's staff visited Pantex to observe ongoing W87 Bay operations and attend the W87 Life Extension Program Engineering Evaluation.

- On January 11-15, 1999, the Board's staff visited Pantex to attend the NSTE-270 nuclear explosive safety study orientation.

- On January 19-22, 1999, the Board's staff visited Pantex to observe the W87 Engineering Evaluation and assess W87 Life Extension Program control implementation.

- On January 26-28, 1999, the Board's staff visited Pantex to observe the W87 Life Extension Program Engineering Evaluation and the W-56 Readiness Assessment Resumption.

- On February 16-19, 1999, the Board's staff visited Pantex to attend the AL-R8 Sealed Insert Qualification Evaluation meeting. 
- On February 16-19, 1999, the Board's staff visited Pantex to observe readiness assessment of W-56 dismantlement program.

- On February 22-25, 1999, the Board's staff visited Pantex to discuss issues related to lightning protection.

- On March 9-12, 1999, the Board's staff visited Pantex to attend a M\&H readiness review for the W87 Life Extension Program.

- On March 15-17, 1999, the Board's staff visited Pantex to review pit storage.

- On March 22-25, 1999, the Board's staff visited Pantex to observe and review the emergency response capability.

- On March 22-26, 1999, the Board's staff visited Pantex to observe the W87 Department of Energy Readiness Review.

- On April 5-7, 1999, the Board's staff visited Pantex to review pit storage.

- On April 7-9, 1999, the Board's staff visited Pantex to review W-56 technical issues and observe the W-87 readiness review.

- On April 12, 1999, the Board's staff visited Pantex to review the safety management of operations.

- On April 12-15, 1999, the Board's staff visited Pantex to review the W56 Hazard Analysis Report ABCD Lessons Learned - PT4174 Nuclear Explosive Safety Study.

- On April 19-22, 1999, the Board's staff visited Pantex to observe B53 End-Cap Nuclear Explosion Safety Study.

- On April 21-22, 1999, the Board's staff visited Pantex to review the W62 follow up project status Standing Management Team meeting.

- On April 27-30, 1999, the Board's staff visited Pantex for the Lightning Protection Team and Explosive Safety Committee meetings.

- On May 4-6, 1999, the Board's staff visited Pantex to review W62 follow up on project status and Hazard Analysis Review.

- On May 20, 1999, the Board visited Pantex for a site visit.

- On June 21-24, 1999, the Board's staff visited Pantex to observe the Mason \& Hanger Corporation Readiness Assessment of ALR8 Sealed Insert Repackaging Program.

- On June 22-24, 1999, the Board's staff visited Pantex to review the W79

Dismantlement Program. 
- On July 14-16, 1999, the Board's staff visited Pantex to observe ALR8 sealed insert first production unit.

- On July 27-28, 1999, the Board's staff visited Pantex to review surveillance and testing activities.

- $\quad$ On July 26-29, 1999, the Board's staff visited Pantex to discuss testing at the Weapons Evaluation Test Laboratory (WETL) and W83 Operations.

- On September 7-10, 1999, the Board's staff visited Pantex to review W62 safety basis and the BIO upgrade transportation module.

- On September 30-October 1, 1999, the Board's staff visited Pantex to support a site visit.

- On October 4-7, 1999, the Board's staff visited Pantex to observe the nuclear explosive safety study.

- $\quad$ On October 25-29, 1999, the Board's staff visited Pantex to observe the Integrated Safety Management System Verification.

- On November 8-10, 1999, the Board's staff visited Pantex to review W62.

- On November 16-19, 1999, the Board's staff visited Pantex to review W62, site wide Technical Safety Report, lightning protection authorization basis, and observe the Lightning Protection Team meeting.

- On December 6-10, 1999, the Board's staff visited Pantex to review W62 readiness assessment and Nuclear Explosive Safety Study.

- On December 13-17, 1999, the Board's staff visited Pantex to observe the W62 Readiness Assessment closeout.

\section{Princeton Plasma National Laboratory}

\section{Rocky Flats}

- On February 17-19, 1999, the Board's staff visited Rocky Flats to discuss ongoing programs at the site.

- On February 22-24, 1999, the Board's staff visited Rocky Flats to discuss residue characterization.

- On February 23-25, 1999, the Board's staff visited Rocky Flats for a radiological work control review. 
- On April 19-23, 1999, the Board's staff visited Rocky Flats to review the implementation of recommendation 94-3.

- On May 3-7, 1999, the Board's staff visited Rocky Flats to review combustible residue plans.

- On May 17-21, 1999, the Board's staff visited Rocky Flats to observe residue processing operations.

- On May 19, 1999, the Board traveled to Rocky Flats for a site visit.

- On June 9-10, 1999, the Board and its staff traveled to Rocky Flats for a site visit.

- $\quad$ On June 14-18, 1999, the Board's staff visited Rocky Flats to review the Plutonium Stabilization and Packaging System Program.

- $\quad$ On August 23-27, 1999, the Board's staff visited Rocky Flats to observe decontamination and decommissioning work.

- On October 12-15, 1999, the Board's staff visited Rocky Flats to review deactivation and decommissioning activities at Building 771, review ventilation at Buildings 371 and 707 , and to discuss demister studies.

- On October 26-29, 1999, the Board's staff visited Rocky Flats to review instrumentation and control activities and the $\mathrm{Y} 2 \mathrm{~K}$ contingency planning.

- On December 7-10, 1999, the Board's staff visited Rocky Flats to observe the size reduction systems review.

\section{Sandia National Laboratory}

\section{Savannah River Site}

- On January 5-6, 1999, the Board's staff visited Savannah River Site to review the consolidated tritium facilities safety analysis report.

- On February 9-12, 1999, the Board's staff visited the Savannah River Site to review the In-Tank Precipitation Facility and to discuss other high-level issues.

- On February 22-25, 1999, the Board's staff visited Savannah River to review the HArea, recommendation 94-1 activities.

- On March 16-18, 1999, the Board's staff visited Savannah River Site to review the canyon exhaust upgrade project design. 
- On April 13-15, 1999, the Board's staff visited the Savannah River Site to review the Americium/Curium project.

- On April 19-23, 1999, the Board's staff visited the Savannah River Site to review the replacement high level waste evaporator.

- On May 4-6, 1999, the Board's staff visited the Savannah River Site to review Plutonium Stabilization and Packaging Alternatives.

- On May 17-21, 1999, the Board's staff visited the Savannah River Site to review the Tritium Extraction Facility.

- On May 25-27, 1999, the Board's staff visited the Savannah River Site to review the H-Canyon Phase 3 Restart Preparations.

- On July 12-13, 1999, the Board's staff visited the Savannah River Site to attend the authorization basis workshop.

- On July 26-28, 1999, the Board's staff visited the Savannah River Site to review the Americium/Curium Stabilization Project.

- On August 16-19, 1999, the Board's staff visited the Savannah River Site to review chemical safety.

- On September 27-29, 1999, the Board's staff visited the Savannah River Site to observe the replacement high level waste evaporator and tank farms safety analysis review.

- On October 4-8, 1999, the Board's staff visited the Savannah River Site to review training and replacement high level waste evaporator conduct of operations.

- On October 18-19, 1999, the Board and its staff visited the Savannah River Site for a site visit.

- On October 18-20, 1999, the Board's staff visited the Savannah River Site to review the tritium extraction facility.

- On October 25-29, 1999, the Board's staff visited the Savannah River Site to review K Area Material Storage and Tank Farms.

- On November 1-5, 1999, the Board's staff visited the Savannah River Site to review the Tritium Consolidation Program.

- On November 29 - December 3, 1999, the Board's staff visited the Savannah River Site to observe the high level waste evaporator replacement, review the design for tritium consolidation project and follow-up on fire protection. 
- On December 8-9, 1999, the Board's staff visited the Savannah River Site to review recommendation $94-1$ activities.

- $\quad$ On December 13-17, 1999, the Board's staff visited the Savannah River Site to review K Area Material Storage.

\section{Waste Isolation Pilot Plant}

- On January 7, 1999, a Board member will visit the Waste Isolation Pilot Plant.

- On January 6-8, 1999, the Board's staff visited the Waste Isolation Pilot Plant to familiarize a Board member with the site.

- On February 8-1 1, 1999 the Board's staff visited the Waste Isolation Pilot Plant to review the Electrical Safety Program and the electrical systems, and follow-up on open items.

- On March 15-17, 1999, the Board's staff visit the Waste Isolation Pilot Plant to observe receipt and underground placement of waste.

- $\quad$ On March 25-30, 1999, the Board's staff visited the Waste Isolation Pilot Plant to observe receipt and underground placement of first waste at the plant.

- On October 25-27, 1999, the Board's staff visited the Waste Isolation Pilot Plant to review the Resource Conservation and Recovery Act permit activities.

\section{West Valley}

\section{PUBLIC MEETINGS HELD IN WASHINGTON, DC}

- On February 3, 1999, the Board held a public meeting on the status of recommendations 95-2 and 93-3.

- On May 25, 1999, the Board held a public meeting on the status of integrating recommendations 95-2 and 98-1.

- $\quad$ On September 9, 1999, the Board held a public meeting on the implementation progress of recommendation 94-1.

- $\quad$ On September 29, 1999, the Board held a public meeting on status of progress of activities associated with the Department's implementation plans for recommendations 95-2 and 98-1. 


\section{$\underline{\text { MISC }}$}

- On February 17-18, 1999, the Board's staff visited Salt Lake City to participate in the Uranium-233 Technical Team meeting.

- On February 22, 1999, the Board's staff visited Santa Fe to attend the Department of Energy Air Monitoring Users group meeting.

- On March 30 - April 1, 1999, the Board's staff visited Las Vegas to discuss pit corrosion.

- On April 27-29, 1999, the Board's staff visited Las Vegas to attend the National Spent Nuclear Fuel Program meeting.

- On July 21-23, 1999, the Board's staff visited Paducah to review the status of the implementation plan for recommendation 95-1.

- On August 3-6, 1999, the Board's staff visited Miamisburg to review stable metal tritide work.

- On November 2-5, 1999, the Board's staff visited Idaho Falls to attend the recommendation 97-1 Technical Team meeting.

- On November 8-10, 1999, a Board member visited Knoxville to attend the Integrated Safety Management Workshop.

- On November 14-17, 1999, a Board member visited Long Beach to attend a session on Integrated Safety Management.

- On November 17-19, 1999, the Board's staff visited Fernald to review handling and packaging of chemical safety and radiation waste.

- On December 14-16, 1999, the Board's staff visited Miamisburg to observe stable metal tritides and organically-bound tritium. 


\section{Appendix C \\ Key Department/Board Correspondence in 1999}

From the Board to the Department:

- On January 8, 1999, the Board sent a letter to the Acting Deputy Secretary of Energy forwarding a staff issue report concerning the Integrated Safety Management Systems at the Hanford Tank Waste Remediation System.

- On January 8, 1999, the Board sent a letter to the Secretary forwarding observations of recent staff reviews of the year 2000 programs a Lawrence Livermore National Laboratory and the Rocky Flats Operations Office.

- On January 15, 1999, the Board sent a letter to the Assistant Secretary for Defense Programs enclosing a Board staff issue report concerning the Readiness Review Program at Pantex.

- On January 15, 1999, the Board sent a letter to the Assistant Secretary for Defense Programs enclosing a staff issue report concerning early identification of health and safety risks and effective controls developed during the design stage of construction projects by the Department and Los Alamos National Laboratory.

- On January 21, 1999, the Board sent a letter to the Secretary announcing the establishment of a new award entitled "Defense Nuclear Facilities Safety Board Safety Leadership Award" that recognizes strong leadership in the continued progression of a productive and safe Department of Energy complex. The first award was given to Victor Stello, retired Principal Deputy Assistant Secretary for Safety and Quality, Office of Defense Programs.

- On February 23, 1999, the Board sent a letter to the President of Lockheed Martin Energy Systems commending them on their efforts in sharing experiences in integrated safety management at the Hanford, Sandia, Nevada, Idaho and the Oak Ridge sites.

- On February 23, 1999, the Board sent a letter to the Assistant Manager for Enrichment Facilities at the Oak Ridge Operations Office commending him on his retirement.

- On February 23, 1999, the Board sent a letter to the Director of the Lawrence Livermore National Laboratory commending work efforts directed toward the safety management upgrade program at the laboratory.

- On March 3, 1999, the Board sent a letter to the Acting Assistant Secretary for Environmental Management expressing concerns about using a systematic approach in the readiness preparations for work at the Hanford's Plutonium Finishing Plant. 
- On March 10, 1999, the Board sent a letter to the Departmental Representative forwarding a copy of the Board's Ninth Annual Report to Congress.

- On March 12, 1999, the Board sent a letter to the Assistant Secretary for Defense Programs forwarding three reports that documented observations of the Board's staff concerning issues related to nuclear explosive operations at the Pantex Plant.

- On March 12,1999, the Board sent a letter to the Assistant Secretary for Defense Programs forwarding a report summarizing a meeting that was held on December 14-15, 1998, concerning the Integrated Pit Storage Program Plan at the Pantex Plant.

- On March 12, 1999, the Board sent a letter to the Secretary accepting the Department's proposal to close the Board's recommendation 94-4.

- On March 18, 1999, the Board sent a letter to the Under Secretary forwarding a staff issue report on the review of Consolidated Tritium Safety Analysis Report for the Savannah River Site Tritium Facilities and commending him on the Department's defense-in-depth approach in establishing the safety measures for the consolidated Tritium Facilities.

- On March 18, 1999, the Board sent a letter to the Acting Deputy Secretary forwarding a list of accepted deliverables for closure under the recommendation 93-3 Implementation Plan.

- On March 19, 1999, the Board sent a letter to the Secretary forwarding a report entitled, Protection of Collocated Workers at the Department of Energy's Defense Nuclear Facilities and Sites (DNFSB/TECH 20) concerning adequate protection of workers at the Department's defense nuclear sites.

- On March 24, 1999, the Board sent a letter to the Under Secretary forwarding a staff issue report on the review of alternative technologies for use in the In-Tank Precipitation Facility at the Savannah River Site.

- On March 25, 1999, the Board sent a letter to the Secretary closing recommendation 931.

- On March 25, 1999, the Board sent a letter to the Secretary accepting the Implementation Plan for recommendation 98-1 and commending the development team for the plan.

- On March 25, 1999, the Board sent a letter to the Under Secretary forwarding a staff issue report on the schedule progress for the Hanford Spent Nuclear Fuel Project.

- On March 25, 1999, the Board sent a letter to the Assistant Secretary for Defense Programs forwarding a staff issue report on lightning protection for nuclear explosive 
areas at Pantex and pointing out the long overdue technical report on this subject request by the Board's letter of September 12, 1999.

- On March 29, 1999, the Board sent a letter to the Acting Assistant Secretary for Environmental Management forwarding a staff issue report concerning technical issues related to the Spent Nuclear Fuel Project at Hanford.

- On April 26, 1999, the Board forwarded a technical report to the Secretary regarding, "Status of Emergency Management at Defense Nuclear Facilities of the Department of Energy, DNFSB/Tech-21."

- On April 27, 1999, the Board sent a letter to the Secretary agreeing with the Department's proposal for closure of recommendation 93-6.

- On April 27, 1999, the Board sent a letter to the Acting Assistant Secretary of Environmental Management commending the improvements in worker protection during decommissioning activities at Rocky Flats.

- On April 29, 1999, the Board sent a letter to the Under Secretary regarding technical issues associated with the detection, control, bioassay, and internal dosimetry. of metal tritides.

- On April 29, 1999, the Board sent a letter to the Secretary commending the efforts of the Government Industry Data Exchange Program.

- On May 4, 1999, the Board sent a letter to the Acting Assistant Secretary for Environmental Management regarding the draft Department Order 435.1, "Radioactive Waste Management," and its supporting manual and guidance.

- On May 6, 1999, the Board sent a letter to the Assistant Secretary for Defense Programs enclosing a staff issue report regarding resumption of operations at Building 332 at Lawrence Livermore National Laboratory.

- On May 6, 1999, the Board sent a letter to the Secretary enclosing a staff issue report on observations of first waste receipt and disposal placement at WIPP.

- On May 7, 1999, the Board sent a letter to the Assistant Secretary for Environment, Safety and Health regarding the cancellation of the June 15-16, 1999, Criticality Workshop for Senior Managers.

- On May 7, 1999, the Board sent a letter to the Manager of the Savannah River Operations Office regarding recent reports in the Occurrence Reporting and Processing System. 
- $\quad$ On May 12, 1999, the Board sent a letter to the Assistant Secretary for Defense Programs enclosing a staff issues report regarding review of conceptual design of Highly Enriched Uranium Storage Facility at the Y-12 Plant.

- On May 14, 1999, the Board sent a letter to the Secretary regarding the Department's efforts to stabilize nuclear materials at Savannah River under the 94-1 implementation plan.

- On May 18, 1999, the Board sent a letter to the Assistant Secretary for Defense Programs regarding steps taken by the Department and Mason and Hanger Corporation to startup or restart certain nuclear explosives operations at the Pantex Plant.

- On May 20,1999, the Board forwarded an announcement to the Department announcing Mark Sautman as the recipient of the John W. Crawford, Jr. Award for Staff Excellence.

- On May 26, 1999, the Board sent a letter to the Acting Assistant Secretary for Environmental Management regarding the Department's Integrated Project Management Plan for the PFP Stabilization and Deactivation Project (IPMP).

- On May 27, 1999, the Board sent a letter to the Acting Assistant Secretary for Environmental Management providing expectations for the Department to further address stabilization plans for neptunium solutions, plutonium metals and oxides.

- On May 27, 1999, the Board sent a letter to the Secretary closing recommendation 94-3.

- $\quad$ On June 8, 1999, the Board sent a letter to the Acting Assistant Secretary of Environmental Management enclosing DNFSB/Technical Report 22 regarding a processing alternative for disposal of aluminum spent nuclear fuel at the Savannah River Site.

- On June 8, 1999, the Board sent a letter to the Secretary enclosing DNFSB/Technical Report 23 regarding HEPA filters used in the Department's Hazardous Facilities.

- $\quad$ On June 10, 1999, the Board sent a letter to the Secretary closing recommendation 94-5.

- On June 11, 1999, the Board sent a letter to the Assistant Secretary for Defense Programs regarding observations of readiness reviews conducted at the Pantex Plant.

- $\quad$ On June 16, 1999, the Board sent a letter to the Secretary accepting the 98-2 implementation plan.

- $\quad$ On June 23, 1999, the Board sent a letter to the Secretary establishing a 30 day reporting requirement on actions to complete the 93-3 implementation plan.

- On July 8, 1999, the Board sent a letter to the Acting Assistant Secretary for Environmental Management enclosing a staff issue report on the design and safety analysis issues associated with the Hanford Spent Nuclear Fuel Project. 
- $\quad$ On July 8, 1999, the Board sent a letter to the Secretary enclosing two staff issue reports on chemical hazards assessments, chemical safety review, and lithium operations at the Y-12 site.

- On July 8, 1999, the Board sent a letter to the Assistant Secretary for Environment, Safety and Health enclosing comments on the final draft guide DOE G 421.1-1.

- On July 8, 1999, the Board sent a letter to the Deputy Secretary enclosing comments on the implementation guide for DOE Order 420.1 and DOE-STD-3009.

- On July 26, 1999, the Board sent a letter to the Assistant Secretary for Defense Programs enclosing a staff issue report on the review of worker protection practices at the Los Alamos National Laboratory.

- On July 30, 1999, the Board sent a letter to the Assistant Secretary for Defense Programs enclosing a staff issue report on the review of the W62 disassembly and inspection program status at the Pantex Plant.

- $\quad$ On August 23, 1999, the Board sent a letter to the Assistant Secretary for Environmental Management accepting the Department's U-233 Program Execution Plan delivered under the 97-1 implementation plan.

- $\quad$ On August 26, 1999, the Board sent a letter to the Deputy Secretary establishing a 60 day reporting requirement concerning readiness reviews and the state of implementation of DOE Order 425.1A.

- $\quad$ On August 27, 1999, the Board sent a letter to the Assistant Secretary for Environmental Management enclosing a staff issue report on the Rocky Flats plutonium stabilization and packaging system.

- $\quad$ On September 9, 1999, the Board sent a letter to the Assistant Secretary for Environment, Safety and Health enclosing a staff issue report regarding the Fifth Integrated Safety Management Lessons Learned Workshop held in Atlanta, GA.

- On September 15, 1999, the Board sent a letter to the Deputy Secretary regarding the Department's contractual arrangements with the Center for Chemical Process Safety and the Institute for Nuclear Power Operations.

- On September 21, 1999, the Board sent a letter to the Acting Assistant Secretary for Defense Programs enclosing a staff issue report on lightning protection for nuclear explosive operations at Pantex.

- On September 22, 1999, the Board sent a letter to the Acting Assistant Secretary for Defense Programs enclosing a staff issue report on the review of electrical, instrumentation and control, and fire protection systems at the Los Alamos National Laboratory. 
- On September 22, 1999, the Board sent a letter to the Acting Assistant Secretary for Defense Programs enclosing a staff issue report on the review of weapon safety specifications for the W76, B83, and W56 nuclear weapons program.

- $\quad$ On September 22, 1999, the Board sent a letter to the Assistant Secretary for Environmental Management with follow-up comments from the recent Public Meeting on the necessary actions to resolve issues hindering implementation of recommendation 94-1.

- On September 24, 1999, the Board sent a letter to the Deputy Secretary enclosing comments regarding the Department 's Facility Representative Program and its recipient for Facility Representative of the Year, Mr. Michael Glasman.

- On October 5, 1999, the Board sent a letter to the Director, Office of Science, enclosing a staff issue report on the fire protection program at the Oak Ridge National Laboratory.

- On October 5, 1999, the Board sent a letter to the Acting Assistant Secretary for Defense Programs, enclosing a staff issue report regarding progress towards implementing integrated safety management at the Nevada Test Site.

- On October 6, 1999, the Board sent a letter to the Deputy Secretary enclosing a staff issue report regarding safety basis for defense nuclear facilities at the Y-12 Plant.

- On October 15, 1999, the Board sent a letter to the Deputy Assistant Secretary for Military Application and Stockpile Management, Office of Defense Programs, acknowledging receipt of a NESS restructuring deliverable 5.5.1(c) per the 98-2 implementation plan.

- On November 2, 1999, the Board sent a letter to the Under Secretary enclosing a staff issue report on work involving stable metal tritides at the Miamisburg Environmental Management Project (MEMP).

- On November 2, 1999, the Board sent a letter to the Acting Assistant Secretary for Defense Programs enclosing a staff issue report regarding Building 9206 deactivation and risk reduction activities at the Oak Ridge Y-12 Plant.

- On November 2, 1999, the Board sent a letter to the Assistant Secretary for Environmental Management enclosing a staff issue report on the review of Building 3019 Ventilation Systems required for Uranium-233 Operations and long-term storage.

- On November 3, 1999, the Board sent a letter to the Assistant Secretary for Environment, Safety and Health enclosing a staff issue report on the review of chemical safety at the Savannah River Site.

- On November 3,1999, the Board sent a letter to the Acting Assistant Secretary for Defense Programs enclosing a staff issue report on the review of weapons dismantlement preparations at the Y-12 Plant. 
- On November 9,1999, the Board sent a letter to the Secretary closing recommendation 93-3.

- On November 9, 1999, the Board sent a letter to the Acting Assistant Secretary for Defense Programs establishing a 30-day requirement addressing how the Department intends to identify the root causes of the problems associated with execution of safety management principles and resolution of technical safety issues at the Y-12 Plant.

- On November 10,1999, the Board sent a letter to Senator Gramm enclosing information regarding the Defense Nuclear Facilities Safety Board's oversight of the Pantex Plant.

- On November 15, 1999, the Board sent a letter to the Secretary closing recommendation 93-5.

- On November 15, 1999, the Board sent a letter to the Assistant Secretary for Environmental Management regarding a letter addressing issues discussed at a recent public meeting on recommendation 94-1.

- On November 22, 1999, the Board sent a letter to the Assistant Secretary for Environmental Management forwarding a staff issue report on the safety analyses for replacement high-level waste evaporator at the Savannah River Site.

- On November 22, 1999, the Board sent a letter to the Acting Assistant Secretary for Defense Programs regarding increasing concern on two problems that threaten the schedule for stockpile stewardship that affects the operations at the Pantex Plant and the Y-12 Plant.

- On November 26, 1999, the Board forwarded a public meeting announcement scheduled for December 8, 1999, in Richland, Washington. The Board will review the Department's progress on stabilization and clean-up activities at the Hanford Site.

- On December 1, 1999, the Board sent a letter to the Assistant Secretary for Environment, Safety and Health forwarding a staff issue report on welding quality deficiencies at the Department of Energy sites.

- On December 1, 1999, the Board sent a letter to the Assistant Secretary for Environmental Management forwarding a staff issue report on hazard identification and establishing a 60-day reporting requirement on the decommissioning process at the Hanford 233-S plutonium concentration facility.

- On December 1, 1999, the Board sent a letter to the Acting Assistant Secretary for Defense Programs forwarding two staff issue reports reviewing the status of W62 disassembly and inspection program relative to recommendation 98-2 and transportation basis for interim operation module at the Pantex Plant.

- On December 6, 1999, the Board sent a letter to the Acting Assistant Secretary for Defense Programs forwarding DNFSB/TECH-24, "Safe Handling of Insensitive High 
Explosive Weapon Subassemblies at the Pantex Plant," and establishing a 90-day reporting requirement on the Department's technical safety basis for handling composite insensitive high explosives and conventional high explosives weapon subassemblies.

- On December 6, 1999, the Board sent a letter to the Deputy Secretary accepting the proposed changes to the Department's long-term storage standard, DOE-STD-3013-99.

- On December 7, 1999, the Board sent a letter to the Acting Assistant Secretary for Defense Programs forwarding a staff issue report on the review of the Tritium Extraction Facility at the Savannah River Site.

- On December 14, 1999, the Board sent a letter to the Acting Assistant Secretary for Defense Programs enclosing a staff issue report reviewing the progress of implementing recommendation 94-1 at the Los Alamos National Laboratory.

- On December 16,1999, the Board sent a letter to the Secretary closing recommendation 95-1.

- On December 21, 1999, the Board forwarded a Public Meeting announcement concerning recommendation 95-2 scheduled to be held on January 20, 2000.

- On December 21, 1999, the Board sent a letter to the Deputy Secretary enclosing a report providing an analysis by the Board staff of the fourth quarter, fiscal year 1999, status report for the Department's 97-2 implementation plan.

- On December 22, 1999, the Board sent a letter to the Acting Assistant Secretary for Defense Programs enclosing a staff issue report concerning electrical, instrumentation and control, and fire protection systems and Year 2000 Program at the Lawrence Livermore National Laboratory.

- On December 22, 1999, the Board sent a letter to the Secretary closing recommendation 94-2.

- On December 23, 1999, the Board sent a letter to the Acting Assistant Secretary for Defense Programs regarding the Tritium Extraction Facility at the Savannah River Site. 


\section{From the Department to the Board:}

- On January 14, 1999, the Manager of the Albuquerque Operations Office sent a letter to the Board forwarding the Los Alamos National Laboratory site assessment report as a deliverable under the Implementation Plan, for the Board's recommendation 97-1, concerning the safe storage of Uranium-233 material.

- On January 22, 1999, the Acting Deputy Assistant Secretary for Nuclear Material and Facility Stabilization, Office of Environmental Management, sent a letter to the Board forwarding a site assessment report that for small quantity holding sites as a deliverable under the Implementation Plan for the Board's recommendation 97-1, concerning the safe storage of Uranium-233 material.

- On January 29, 1999, the Acting Manager of Richland Operations Office sent a letter to the Board forwarding a quarterly report for October through December 1998 under the 93-5 Implementation Plan.

- On February 1, 1999, the Acting Assistant Secretary for Environmental Management sent a letter to the Board forwarding a quarterly progress report under the 94-2 Implementation Plan and responding to the Board's November 18, 1998, letter concerning 94-2 implementation.

- On February 2, 1999 the Acting Assistant Secretary for Environmental Management sent a letter to the Board responding to issues raised in the Board's December 1, 1998, letter concerning a Staff Issue Report, "Review of Electrical, Control, Fire Protection, and Ventilation Systems for the Cold Vacuum Drying Facility at the Hanford Spent Nuclear Fuel Project."

- On February 8, 1999, the Under Secretary sent a letter to the Board responding to a December 14, 1998, letter concerning the Board's review of the Department of Energy's draft standard DOE-SAFT-0067, Criteria for Packaging and Storing Uranium-233Bearing Materials.

- On February 12, 1999, the Chief Information Officer sent a letter to the Board responding to a January 8, 1999, letter concerning the Year 2000 (Y-2K) compliance of all safety-related systems; and informing the Board that the requested report would be provided the week of March.

- On February 16, 1999, the Executive Secretary to the Federal Technical Capability Panel sent a letter to the Board forwarding the Facility Representative Personnel Guide, as a deliverable under the Implementation Plan for the Board's recommendation 93-3.

- On February 16, 1999, the Executive Secretary to the Federal Technical Capability Panel sent a letter to the Board forwarding the Phase I Assessment reports as a deliverable under the Implementation Plan for the Board's recommendation 93-3. 
- On February 16, 1999, the Deputy Assistant Secretary for Military Application and Stockpile Management for Defense Programs sent a letter to the Board forwarding a copy of the Strategy for Managing Risks at the Chemistry Metallurgy Research Facility at Los Alamos National Laboratory as the latest information on risk to operations from a seismic event.

- On February 17, 1999, the Assistant Secretary for Defense Programs sent a letter to the Board forwarding copies of deliverables associated with the resumption of Phase A-2 Enriched Uranium Operations at the Y-12 Plant as a deliverable under the Implementation Plan for recommendation 94-4, and proposing closure of the recommendation.

- On February 17, 1999, the Acting Deputy Assistant Secretary for Nuclear Material and Facility Stabilization sent a letter to the Board forwarding the Department's Annual Report of activities related to the implementation of recommendation 97-1, Safe Storage of Uranium-233.

- On February 22, 1999, the Executive Secretary to the Federal Technical Capability Panel sent a letter to the Board forwarding a document entitled, Technical Leadership Development Program Guidance Framework as a deliverable under the Implementation Plan for recommendation 93-3.

- $\quad$ On February 23, 1999, the Acting Deputy Assistant Secretary for Research and Development for Defense Programs sent a letter to the Board forwarding a quarterly status report for the Implementation Plan for recommendation 97-2.

- On February 19, 1999, the Manager of Savannah River Operations Office sent a letter to the Board reporting that the commitment concerning the relocation of tritium loaded reservoirs in long-term storage into highly invulnerable encased safes was completed ahead of schedule.

- On February 26, 1999, the Acting Assistant Secretary for Environmental Management sent a letter to the Board advising them that the Department will not be able to meet the commitment that concerns the removal of deposits of uranium from the Auxiliary Charcoal Bead of the Molten Salt Reactor Experiment at Oak Ridge on its original schedule.

- On February 26, 1999, the Acting Assistant Secretary for Environmental Management sent a letter to the Board advising on the status of the Department's Implementation Plan for the Remediation of Nuclear Materials at the Defense Nuclear Complex, (revision 1).

- On March 2, 1999, the Assistant Secretary for Defense Programs sent a letter to the Board proposing closure of recommendation 93-1. 
- On March 5, 1999, the Chief Information Officer sent a letter to the Board forwarding a report on the safety-related systems at defense nuclear facilities and their schedule for the Year 2000 remediation.

- On March 10, 1999, the Secretary sent a letter to the Board notifying them that an additional 45 days is needed to complete preparation of the implementation plan for addressing the issues raised concerning recommendation 98-2.

- On March 10,1999, the Secretary sent a letter to the Board forwarding implementation plan for recommendation 98-1 concerning revolution of the Department's internal oversight findings.

- On March 15, 1999, the Director of the Weapon Programs Division at the Albuquerque Operations Office, sent a letter to the Board forwarding four new chapters to the Albuquerque Supplemental Directive 56XB, the Development and Production Manual.

- On March 26, 1999, the Acting Deputy Assistant Secretary for Nuclear Material and Facility Stabilization, Office of Environmental Management, sent a letter to the Board forwarding a response to Board letter dated January 28, 1999, regarding the conditional acceptance of the 94-1 implementation plan.

- On March 26, 1999, the Director of the Safety Management Implementation Team sent a letter to the Board forwarding a charter for the Integrated Corrective Action Management Team that will oversee the development and implementation of a computerized Corrective Action Tracking System as part of the Implementation Plan for recommendation 98-1.

- On April 2,1999, the Secretary sent a letter to the Board recommending closure of the Board's recommendation 93-6.

- On April 6, 1999, the Manager for the Office of River Protection, Richland Operations Office, site sent a letter to the Board proposing closure of commitment under recommendation 93-5 Implementation Plan, entitled "Approved Final Safety Analysis Report".

- On April 6, 1999, the Manager of the Office of River Protection, Richland Operations Office, sent a letter to the Board forwarding the final approved safety analysis report for the Tank Waste Remediation System.

- On April 7, 1999, the Chief Information Officer sent a letter to the Board forwarding an updated listing of safety-related systems and their Y2K status.

- On April 12, 1999, the Acting Deputy Assistant Secretary for Nuclear Materials and Facility Stabilization, Office of Defense Programs, sent a letter to the Board forwarding a list of accepted deliverables for closure under the recommendation 94-1 Implementation Plan. 
- On April 13, 1999, the Director of Weapon Programs Division, Albuquerque Operations Office, sent a letter to the Board forwarding approved W62 and W88 project plans.

- On April 14, 1999, the Acting Assistant Secretary for Environmental Management sent a letter to the Board enclosing the "Low -Level Waste Management Program Research and Development Implementation Plan," as a deliverable under the 94-2 Implementation Plan.

- On April 15, 1999, the Assistant Secretary for Defense sent a letter to the Board forwarding responses to issues and comments provided by the Board's March 12, 1999, letter regarding the Integrated Pit Storage Program Plan at the Pantex Plant.

- On April 15, 1999, the Manager of the Office of River Protection sent a letter to the Board enclosing the report HNF-4240, "Organic Solvent Topical Report, Revision 0," to complete various milestones under the Department's 93- 5 Implementation Plan.

- On April 19, 1999, the Acting Assistant Secretary for Nuclear Material and Facility Stabilization sent a letter to the Board enclosing the "Technical Handbook of $233 \mathrm{U}$ Material Properties, Processing, and Handling Guidelines (ORNL/TM-13600)." This report represents deliverable commitment 13 of the Department's Implementation Plan for Board recommendation 97-1.

- On April 22, 1999, the Acting Assistant Secretary for Environmental Management sent a letter to the Board enclosing the 94-3 quarterly status report.

- On April 22, 1999, the Secretary sent a letter to the Board enclosing the 98-2 implementation plan, "Safety Management at the Pantex Plant."

- On April 23, 1999, the Director of the Weapon Program Division sent a letter to the Board updating the status of the revision to several chapters of the AL Supplemental Directive 56XB, the Development and Production (D\&P) Manual.

- On April 26, 1999, the Acting Deputy Assistant Secretary for Nuclear Material and Facility Stabilization sent a letter to the Board forwarding information on three conditions concerning the Implementation Plan for recommendation 94-1, Remediation of Nuclear Materials in the Defense Nuclear Facilities Complex.

- On April 28, 1999, the Acting Assistant Secretary for Environmental Management sent a letter to the Board enclosing the quarterly progress report on the implementation of Board recommendation 94-2 for the period of January 1 through March 31, 1999.May 11,1999 , the Board forwarded a staff issues report to the Assistant Secretary for Defense Programs regarding the resumption of operations and integrated safety management at the Pajarito laboratory, Los Alamos National Laboratory.

- On April 29, 1999, the Manager of the Office of River Protection sent a letter to the Board enclosing the January to March Quarterly Report for Department's Implementation plan 93-5. 
- On April 30, 1999, the Chief Information Officer sent a letter to the Board ensuring that the safety-related systems at the Department's defense nuclear facilities have been identified and that appropriate action is set to resolve any Year 2000 issues.

- On May 10, 1999, the Acting Assistant Secretary for Environmental Management sent a letter to the Board discussing a budget funding decrease to the Actinide Packaging and Storage Facility and its resulting effects to the Department's 94-1 Implementation Plan.

- On May 11, 1999, the Deputy Assistant Secretary for Military Application and Stockpile Management, Office of Defense Programs, sent a letter to the Board enclosing the report, "Lightning Protection Project Team Report on the risk from lightning in Pantex nuclear explosive areas."

- On May 19, 1999, the Executive Secretary for the Federal Technical Capability Panel sent a letter to the Board proposing closure of commitment 5.5.2 per the 93-3 implementation plan.

- On May 19, 1999, the Executive Secretary for the Federal Technical Capability Panel sent a letter to the Board enclosing a summary report fulfilling commitment 5.3.1 per the 93-3 implementation plan, and proposing closure of the commitment.

- On May 26, 1999, the Executive Secretary for the Federal Technical Capability Panel sent a letter to the Board enclosing the annual report on the status of Federal Technical Capability related to the Safe Operation of Defense Nuclear Facilities.

- On May 26, 1999, the Acting Deputy Assistant Secretary for Research and Development, Office of Defense Programs, sent a letter to the Board enclosing the quarterly status report for the second quarter, Fiscal Year 1999, per the 97-2 implementation plan.

- On May 27, 1999, the Assistant Secretary for Environmental Management sent a letter to the Board as a notification of a late commitment per the 94-1 implementation plan.

- $\quad$ On May 28, 1999, the Deputy Assistant Secretary for Military Application and Stockpile Management, Office of Defense Programs, sent a letter to the Board providing commitments 5.5.1-1 and 5.5.2-1 per the 98-2 implementation plan.

- On June 2, 1999, the Savannah River Operations Office Manager sent a letter to the Board regarding corrective actions taken to address the negative trend in control of work and operations at the Savannah River Site.

- On June 3, 1999, the Albuquerque Operations Office Manager sent a letter to the Board enciosing commitment deliverables per the 98-2 implementation plan.

- On June 3, 1999, the Albuquerque Operations Office Manager sent a letter to the Board enclosing commitment 5.6.3 per the 98-2 implementation plan. 
- On June 10,1999, the Under Secretary sent a letter to the Board responding to a Board letter dated April 29, 1999, regarding appropriate radiation protection measures for detecting, controlling, and monitoring metal tritides.

- On June 14, 1999, the Acting Deputy Assistant Secretary for Nuclear Materials and Facility Stabilization, Office of Defense Programs, sent a letter to the Board regarding early completion of a Rocky Flats residue stabilization commitment per the 94-1 implementation plan.

- On June 23, 1999, the ISP Project Officer, Weapon Programs Division, Albuquerque Operations Office, sent a letter to the Board enclosing the revised W88 project plan.

- On June 28, 1999, the Albuquerque Operations Office Manager sent a letter to the Board enclosing the Development \& Production (D\&P) Manual Chapter 11.6, per the 98-2 implementation plan.

- On June 30, 1999, the Oak Ridge Operations Office Assistant Manager for Laboratories sent a letter to the Board enclosing the Oak Ridge National Laboratory (ORNL) Final Site Assessment Report per the 97-1 implementation plan.

- On June 30, 1999, the Albuquerque Operations Office Manager sent a letter enclosing nine of the eleven deliverables due in the month of June per the 98-2 implementation plan.

- On July 2, 1999, the Secretary sent a letter to the Board enclosing a report on issues related to material stabilization activities at the Savannah River Site in response to the Board's reporting requirement of January 28, 1999.

- On July 2, 1999, the Assistant Secretary for Defense Programs sent a letter to the Board in response to a Board letter dated June 11, 1999, regarding readiness reviews at Pantex.

- On July 8, 1999, the Office of River Protection Manager, Richland Operations Office, sent a letter to the Board reporting completion of recommendation 93-5 commitment 5.6.3.1.j.

- On July 9, 1999, the Acting Assistant Secretary for Environmental Management sent a letter to the Board enclosing the Program Execution Plan for safe storage of uranium233, the final deliverable under the implementation plan for recommendation 97-1.

- On July 22, 1999, the Acting Deputy Assistant Secretary for Nuclear Materials and Facility Stabilization sent a letter to the Board providing an update and notification of activities at the Hanford Plutonium Finishing Plant. A copy of the Integrated Project Management Plant was included with the letter.

- On July 29, 1999, the Manager for the Office of River Protection at the Hanford Site sent a letter to the Board providing the Quarterly Report for April through June 1999 per the 93-5 implementation plan. 
- On August 3, 1999, the Executive Secretary for the Federal Technical Capability Panel sent a letter to the Board providing Commitment 5.3.3, the Technical Leadership Development Program Plan per the 93-3 implementation plan.

- On August 19, 1999, the Acting Deputy Secretary for Research and Development, Defense Programs sent a letter to the Board enclosing the third quarterly status progress report per the 97-2 implementation plan.

- On August 23, 1999, the Deputy Assistant Secretary for Military Application and Stockpile Management, Office of Defense Programs, sent a letter to the Board enclosing a decision report required in deliverable 5.5.1(c) per the 98-2 implementation plan.

- $\quad$ On August 27, 1999, the Assistant Secretary for Environmental Management sent a letter to the Board enclosing the quarterly progress report for the 94-2 implementation plan.

- On September 2, 1999, the Executive Secretary for the Federal Technical Capability Panel sent a letter to the Board enclosing the revised TQP implementation plan (commitment 5.4.3) per the 93-3 implementation plan.

- On September 2, 1999, the Acting Deputy Assistant Secretary for Nuclear.Materials and Facility Stabilization, Office of Environmental Management, sent a letter to the Board enclosing a report on the on-schedule completion and proposed closure of commitment 310 per the 94-1 implementation plan.

- On September 7, 1999, the Albuquerque Operations Office Manager sent a letter to the Board enclosing a report with details on deliverables for the 98-2 implementation plan due within the month of August.

- On September 29, 1999, the Assistant Secretary for Environmental Management sent a letter to the Board regarding the Rocky Flats Environmental Technology Site's (RFETS) Plutonium Stabilization and Packaging System's (PuSPS) ability to meet the DOE-STD3013-96 requirement to limit the contamination level of the outer surface of the inner can as defined in 10 CFR 835.

- On September 28, 1999, the Assistant Secretary for Environmental Management sent a letter to the Board enclosing the compliance evaluation and the disposal authorization statement for the Savannah River Site E-Area Vaults and Saltstone disposal facilities.

- On September 24, 1999, the Manager of the Office of River Protection, Richland Operations Office, sent a letter to the Board enclosing milestone 5.4.3.6.d per the 93-5 implementation plan.

- On September 20, 1999, the Assistant Secretary for Environmental Management sent a letter to the Board in response to their July 8, 1999, letter concerning completion of the Hanford Spent Nuclear Fuel Project. 
- On September 17, 1999, the Acting Deputy Assistant Secretary for Nuclear Material and Facility Stabilization, Office of Environmental Management, sent a letter to the Board reporting completion of a 94-1 implementation plan commitment to initiate operation of the prototype denitration calciner at Hanford.

- On September 10,1999, the Albuquerque Operations Office Manager sent a letter to the Board enclosing the Pantex Plant ISMSV Phase I Review Plan per the 98-2 implementation plan.

- On September 28, 1999, the Executive Secretary to the Federal Technical Capability Panel sent a letter to the Board enclosing deliverables for commitments related to improvements in the Technical Qualifications Program.

- On October 5, 1999, the Albuquerque Operations Office Manager sent a letter to the Board providing details on the deliverables due within the month of September per the 98-2 implementation plan.

- On October 5, 1999, the Director, Safety Management Implementation Team sent a letter to the Board providing a printout of the Corrective Action Tracking System database per the 98-1 implementation plan.

- On October 12,1999, the Secretary of Energy sent a letter to the Board accepting recommendation 99-1 concerning the safe storage of pits.

- On October 13, 1999, the Secretary of Energy sent a letter to the Board enclosing a report providing the completion status of the commitments per the 93-3 implementation plan, the rationale for closing recommendation 93-3, and the Department's plan to continue the Federal Technical Capability Program.

- On October 15, 1999, the Assistant Secretary for Environmental Management sent a letter to the Board responding to questions relative to issues discussed during the Public Meeting held on September 9, 1999, regarding recommendation 94-1.

- On October 19, 1999, the Deputy Secretary of Energy sent a letter to the Board describing a path forward for the implementation of DOE Order 425.1A, and requesting an additional 60 days to provide a comprehensive report on readiness process implementation.

- On October 19, 1999, the Director, Safety Management Implementation Team sent a letter to the Board enclosing the revised Functions, Responsibilities, and Authorities Manual (DOE M 411.1-1A), and its Quality Assurance Order (DOE O 414.1A).

- On October 20, 1999, the Assistant Secretary for Environmental Management sent a letter to the Board enclosing the compliance evaluation and the disposal authorization for the Nevada Test Site Area 3 Radioactive Waste Management Site performance assessment and composite analysis. 
- On October 25, 1999, the Assistant Secretary for Environmental Management sent a letter to the Board forwarding the review of Hanford Site Composite Analysis and Disposal Authorization Statements for disposal facilities.

- On October 27, 1999, the Office of River Protection Manager, Richland Operations Office, sent a letter to the Board enclosing the quarterly report for July 1999 through September 1999, per the 93-5 implementation plan.

- On October 29, 1999, the Secretary sent a letter to the Board proposing closure of recommendation 93-5.

- On October 29, 1999, the Savannah River Operations Manager sent a letter to the Board enclosing the technical rationale requested by the Board staff on the seismic issue, Issue $3 a$.

- On November 4, 1999, the Albuquerque Operations Office Manager sent a letter to the Board providing details on deliverables due within the month of October per the 98-2 implementation plan.

- On November 4, 1999, the Deputy Assistant Secretary for Research, Development and Simulation, Office of Defense Programs, sent a letter to the Board enclosing the Fourth Quarterly Status Report for Fiscal Year 1999 per the 97-2 implementation plan.

- On November 5, 1999, the Acting Deputy Assistant Secretary for Nuclear Materials and Facility Stabilization, Office of Environmental Management, sent a letter to the Board reporting early completion and requesting closure of one of the commitments found in the 94-1 implementation plan.

- On November 12,1999, the Under Secretary sent a letter to the Board enclosing the updated policy approach on radiation protection measures for metal tritides and organically-bound tritium.

- On November 17, 1999, the Acting Deputy Assistant Secretary for Science and Technology, Office of Environmental Management, sent a letter to the Board forwarding a compilation of the current research activities of the Office of Science and Technology to implement the Low-Level Waste Research and Development Plan developed by the Department in response to recommendation 94-2.

- On November 24, 1999, the Assistant Secretary for Environmental Management sent a letter to the Board forwarding four revised guidance documents for the Department of Energy's Low-Level Waste Disposal Facility Performance Assessments and Composite Analyses.

- On December 6, 1999, the Deputy Assistant Secretary for Military Application and Stockpile Operations, Office of Defense Programs, sent a letter to the Board enclosing revised DOE Orders 452.1B/452.2B concerning nuclear explosive operations and the Nuclear Explosive Safety Study Group implementation guidance. 
- On December 6, 1999, the Secretary sent a letter to the Board addressing issues raised in a May 1999 Technical Report, DNFSB-Technical 23, HEPA Filters used in the Department of Energy's hazardous facilities.

- On December 10, 1999, the Deputy Assistant Secretary for Military Application and Stockpile Operations, Office of Defense Programs, sent a letter to the Board enclosing the revised standard, DOE-STD-3015-97, Nuclear Explosive Safety Study Process, per the 98-2 implementation plan.

- On December 13, 1999, the Assistant Secretary for Environmental Management sent a letter to the Board enclosing the compliance evaluation and the disposal authorization for Solid Waste Storage Area 6 (SWSA-6) low-level waste disposal in Tumulus I, Tumulus II, and Interim Waste Management Facility (IWMF) at the Oak Ridge Reservation (ORR).

- On December 15, 1999, the Assistant Secretary for Environmental Management sent a letter to the Board responding to a Board letter dated November 22, 1999, relative to the safety analyses for the Replacement High-Level Waste Evaporator at the Savannah River Site.

- On December 16, 1999, the Acting Assistant Secretary for Defense Programs sent a letter to the Board regarding the progress of Integrated Safety Management at the Nevada Test Site.

- December 16, 1999, the Deputy Assistant Secretary for Military Application and Stockpile Operations, Office of Defense Programs, sent a letter enclosing revisions on the operations requirements project plan for the W76 and W88 Disassembly and Inspection at the Pantex Plant in responșe to Board letter dated November 22, 1999.

- On December 22, 1999, the Deputy Secretary sent a letter to the Board providing a report on the implementation status of DOE Order 425.1A, Startup and Restart of Nuclear Facilities.

- On December 22, 1999, the Acting Assistant Secretary for Defense Programs sent a letter to the Board responding to a Board letter dated November 2, 1999, regarding increasing concerns on risk reduction activities in Building 9206 at the Oak Ridge Y-12 Plant.

- On December 30, 1999, the Acting Assistant Secretary for Defense Programs sent a letter to the Board enclosing a preliminary list of root causes of problems in safety management and technical safety issues at the Oak Ridge Y-12 Plant. The letter also requested an extension on the reporting requirement for the corrective actions established in the Board's letter dated November 9, 1999. 